\title{
International Union of Crystallography Twelfth General Assembly and International Congress of Crystallography Ottawa, Canada, 16-25 August 1981
}

Table of Contents

Introduction and Opening Ceremony . . . . . . . . Twelfth International Congress . . . . . . . . . .

Minutes of the Twelfth General Assembly

Introduction and list of delegates

First Session, Monday 17 August 1981, 7.00 p.m.

(1) Introductory remarks by the President . . . . .

(2) Procedural matters . . . . . . . . . . .

(3) Approval of Agenda . . . . . . . . . . . .

(4) Application for membership of the Union . . . .

(5) Replacement of an Adhering Body . . . . . . . .

(6) Approval of Minutes of the Eleventh General Assembly . . . . . . . . . . . . . . .

(7) Report of the Executive Committee . . . . . .

(8) Financial Report . . . . . . . . . . . . .

(9) Establishment of an in-house computerized typesetting system . . . . . . . . . . . . .

(10) Reports of the Commissions . . . . . . . . .

(11) Commmission on Journals . . . . . . . . . .

(12) Commission on Structure Reports . . . . . . .

(13) Commission on Charge, Spin and Momentum Densities . . . . . . . . . . . . . . .

(14) Commission on Crystal Growth . . . . . . . .

(15) Commission on Crystallographic Apparatus . . .

(16) Commission on Crystallographic Computing . . .

(17) Commission on Crystallographic Data . . . . .

(18) Commission on Crystallographic Nomenclature . .

(19) Commission on Crystallographic Teaching . . . .

(20) Commission on Electron Diffraction . . . . . .

(21) Commission on Neutron Diffraction . . . . .

(22) Determination of the number of elected members of each Commission . . . . . . . . . . . .

Second Session, Tuesday 18 August 1981, 7.08 p.m.

(23) Addition to the Agenda . . . . . . . . . .

(24) Confirmation of the date and place of the Thirteenth General Assembly . . . . . . . . . . . .

(25) Establishment of Finance and Long-Range Planning Committees . . . . . . . . . . . . . .

(26) Commission on International Tables . . . . . . .

(27) Commission on Crystallographic Studies at Controlled Pressures and Temperatures . . . . .

(28) Change of name of the Commission on Crystal Growth . . . . . . .

(29) Establishment of a Commission on Biological Macromolecular Crystallography . . . . . .

(30) Reports of the Representatives on Scientific and Regional Associates . . . . . . . . . . . . .

(31) Reports of the Representatives on bodies not belonging to the Union . . . . . . . . .

(32) ICSU Abstracting Board . . . . . . . . . .

(33) ICSU Committee on Science and Technology in Developing Countries (COSTED) . . . . . .
(34) ICSU Committee on Space Research (COSPAR) .

(35) Sub-committee on the Union Calendar . . . . .

(36) Consideration of provision for individual scientists to become members of the Union . . . . . .

Third Session, Saturday 22 August 1981, 7.00 p.m.

(37) Election of Chairmen and members of Commissions

(38) Election of Representatives on bodies not belonging to the Union and on Regional and Scientific Associates . . . . . . . . . . . .

(39) Election of Officers of the Union . . . . . . .

(40) Date and place of the Fourteenth General Assembly

(41) Change in the unit of currency for subscriptions . .

(42) Change in the unit of currency used for the Union's accounts . . . . . . . . . . . .

(43) Determination of the general policy and the timetable for the period to the Thirteenth General Assembly . . . . . . . . . . . . . . .

(44) Preliminary consideration of activities for the period 1984 to 1987.

(45) Budget estimates and unit contribution for the period until the Thirteenth General Assembly . .

(46) Confirmation of the appointments of the Editors of the publications of the Union . . . . . . . .

Fourth Session, Tuesday 25 August 1981, 2.30 p.m.

(47) Good wishes and votes of thanks . . . . . . .

(48) Unit contribution for the period until the Thirteenth General Assembly .

(49) Donations to the Union

(50) A charge for publishing? . . . . . . . . . .

(51) European Crystallographic Committee . . . . .

(52) Votes of thanks . . . . . . . . . . . . .

Closing Ceremony, Tuesday 25 August, 1.00 p.m.

Votes of thanks . . . . . . . . . . . . .

Annex I: Appendices to the Agenda of the Twelfth General Assembly . . . . . . . .

(A) Report of the Executive Committee . . . . . . .

(B) Financial Report . . . . . . . . . . . . .

(C) In-House Computerized Typesetting System . . .

(D) Reports of the Commissions of the Union . . . .

(E) Reports of the Representatives on Scientific and Regional Associates .. . . . . . . . . . .

(F) Reports of the Representatives on bodies not belonging to the Union . . . . . . . . . . . . . . .

(G) Summary of the activities of the Sub-committee on the Union Calendar

(H) Consideration of provision for individual scientists to become members of the Union

(I) Budget estimates for the period until the Thirteenth General Assembly: determination of the unit contribution

(J) A charge for publishing? 
Annex II: Statutes and By-Laws of the Union . . . .

Annex III: Committees, Commissions, Regional and Scientific Associates and Representatives on other bodies . . . . . . . . . .

Annex IV: Adhering Bodies and National Committees for Crystallography . . . . . . . .

\section{Introduction and Opening Ceremony}

By invitation of the National Research Council of Canada, the Twelfth General Assembly and International Congress of Crystallography were held at Carleton University, Ottawa, Canada, 16-25 August 1981.

The meetings were attended by 1334 scientists of whom 116 were from Canada, and the remainder from the following 38 countries: Algeria, Argentina, Australia, Austria, Belgium, Brazil, Chile, People's Republic of China, Cuba, Czechoslovakia, Denmark, Egypt, Finland, France, German Democratic Republic, Federal Republic of Germany, Hong Kong, Hungary, India, Israel, Italy, Japan, Korea, Malaysia, Mexico, The Netherlands, New Zealand, Norway, Poland, Portugal, South Africa, Spain, Sweden, Switzerland, USSR, UK, USA, Yugoslavia.

The General Assembly and Congress were opened formally on the morning of 17 August at a ceremony held at the National Arts Centre, Ottawa. The opening ceremony commenced with speeches of welcome from the Chairman of the Organising Committee, Dr L. D. CALverT, the Chairman of the Canadian National Committee for Crystallography, Professor F. W. B. Einstein, and the President of the National Research Council of Canada, Dr L. KerwiN. Professor N. Kato, President of the IUCr, replied on behalf of the Union and read out a message of good wishes from Professor P. P. Ewald. Professor DoRothy HodGKIN presented the Congress Discourse entitled Insulin in Crystals. After a short intermission there followed a recital by the Cantata Singers of Ottawa, two films, Ottawa, Canada's Capital and National Parks, and a reception.

\section{Twelfth International Congress}

\section{Scientific programme}

The scientific programme included the Congress Discourse by Professor Hodgkin mentioned above and 10 Main Lectures: X-ray Structural Studies of Icosahedral Viruses by M. G. Rossmann; Quantitative Aspects of Systematic Crystal Chemistry by W. B. Pearson; Synchrotron Radiation and Anomalous Dispersion by H. B. Stuhrmann; Superspace Groups in Crystallography by A. Janner; Flexibility and Dynamics of Protein Structures by D. C. Phillips; The Renaissance of Powder Diffraction: From Ugly Duckling to Beautiful Swan by J. I. Langford; Interactive Computer Graphics in Structure Analysis by W. V. Wright; Use of Lattice Imaging in the Study of Minerals by $\mathrm{N}$. Morimoto; Crystallographic Engineering by R. E. Newnham; Recent Developments in Charge Density Studies by F. L. Hirshfeld; Crystals, Molecules and Chemists by P. Murray-Rust; Recent Developments in Crystal Growth Science by A. A. Chernov. Two Main Lectures were held on most mornings and these were followed by five or six microsymposia, held in parallel. Some of the microsymposia were organized by Commissions of the Union and others by
Chairmen selected by the Programme Committee. Each microsymposium, of which there were 43 in all, provided a summary of the present status of a particular area of research. The afternoons were devoted to poster sessions. In all 1087 papers were presented, 229 in oral sessions and the remainder in poster sessions. The detailed plan for the Scientific Programme had been compiled by an international Programme Committee at a preparatory meeting in August 1980. The abstracts submitted were printed, by direct reproduction of typescript copy, in a book of Collected Abstracts and in a Supplement to Acta Crystallographica, Section A.

\section{Exhibits}

An exhibition of commercial crystallographic equipment, an exhibition of crystallographic books and an exhibition of non-commercial apparatus and items related to the artistic side of crystallography were held in different parts of the University campus.

\section{Database demonstrations}

Demonstrations were given of the following databases: the Cambridge Crystallographic Database; the Inorganic Crystal Structure Database; the Powder Diffraction File; the Metal Data File and Minicomputer Crystal Structure Package.

\section{Social events}

A reception, a wine and cheese party and a congress excursion to Gatineau Park were organized for all participants, while a more extensive programme was arranged for those accompanying the Congress participants.

\section{Scientific tours}

There were three day trips organized, to the Atomic Energy of Canada Laboratories, to Mount St Hilaire and to Ottawa area mines.

\section{Minutes of the Twelfth General Assembly}

These Minutes have been prepared by D. W. Penfold, acting for the Executive Secretary, under the authority of S. E. Rasmussen, General Secretary and Treasurer of the Union and Secretary of the General Assembly.

\section{Introduction and list of delegates}

Sessions of the General Assembly were held on the evenings of Monday 17 August, Tuesday 18 August and Saturday 22 August and on the afternoon of Tuesday 25 August, in Room 356 of the Herzberg Building at Carleton University. The following list shows the names of official delegates appointed by the Adhering Bodies and of the alternates who substituted at one or more sessions. The names are listed by the countries to which the respective Adhering Bodies belong, and the number of votes of the Adhering Body is given in parentheses after the name of each country. The names of the Chairmen of the delegations are printed in bold type; those of alternates are marked by an asterisk. The names of officially appointed delegates who were not present at any session of the Assembly are not included. 
Argentina (1): A. Podjarny (present on 17 and 18 August), M. A. R. de Benyacar* (present on 22 and 28 August).

Australia (3): H. Freeman (present on 22 and 25 August), P. Goodman* (present on 22 and 25 August), S. R. Hall* (present on 17 and 18 August), E. N. Maslen, T. M. Sabine (present on 17 and 18 August).

Austria (1): A. Preisinger (absent on 17 August).

Belgium (2): H. Brasseur, G. S. D. King.

Brazil (3): S. Caticha Ellis (absent on 25 August), Y. P. Mascarenhas.

Canada (3): F. R. Brisse, F. W. B. Einstein, C. P. Huber.

Chile (1): U. Wittke (present only on 22 and 25 August).

China, People's Republic of (4): Guo Changling, Huang Jinling, Liang Dongcai, Tang You-qi (all absent on 25 August).

Czechoslovakia (1): J. Garaj (absent on 18 August), A. Linek* (present only on 18 August).

Denmark (1): J. Danielsen.

Egypt, Arab Republic of (1): M. S. Ahmed (present only on 17 and 22 August).

Finland (1): K. V. J. Kurki-Suonio.

France (4): A. Authier, P. Becker, M. Lambert, J. Meinnel.

German Democratic Republic (2): E. Hoehne, G. Koetitz.

Germany, Federal Republic of (4): H. Burzlaff (absent on 22 August), W. Eysel* (present only on 22 and 25 August), K. Fischer, K.-J. Range (absent on 25 August), W. Saenger* (present only on 22 August), H. Wondratschek (absent on 22 August).

Hungary (1): P. Gado* (present only for part of session on 25 August), L. Zsoldos (absent for part of session on 25 August).

India (1): N. N. Saha.

Israel (1): J. Bernstein (absent on 25 August), D. Rabinovich* (present only on 25 August).

Italy (3): G. Allegra (absent on 22 and 25 August), A. Coda, G. Filippini* (present only on 22 and 25 August), A. Vaciago (absent on 25 Aügust).

Japan (4): T. Ashida (absent on 25 August), S. Hoshino, S. Hosoya* (present only on 25 August), K. Kuchitsu* (present only on 25 August), Y. Takeuchi (absent on 25 August), D. Watanabe.

Netherlands (3): P. T. Beurskens* (present only on 25 August), M. G. Northolt* (present only on 22 August), $H$. Schenk (absent on 25 August), P. M. de Wolff (absent on 22 August).

New Zealand (1): G. Gainsford.

Norway (1): J. Hvoslef (absent on 25 August), B. F. Pedersen* (present only on 25 August).

Poland (1): M. J. Grabowski* (present only on 25 August), K. Kukaszewicz (absent on 22 and 25 August).

Portugal (1): L. M. Alte da Veiga (absent on 18 August).

South Africa (1): L. R. Nassimbeni.

Spain (3): S. García-Blanco, S. Martínez-Carrera.

Sweden (2): S. Abrahamsson, P. Kierkegaard.

Switzerland (2): H. B. Bürgi (present only on 25 August), G. Chapuis* (present only on 22 August), H. D. Flack* (absent on 17 August), E. Kaldis* (present only on 17 August), W. M. Meier (absent on 22 and 25 August).

$U K$ (5): D. M. Blow, G. A. Sim, C. A. Taylor, E. J. W. Whittaker, M. M. Woolfson.

USA (5): S. C. Abrahams, J. P. Glusker (absent for part of session on 25 August), G. A. Jeffrey (absent for part of session on 25 August), H. Steinfink, R. A. Young.
USSR (5): V. V. Barynin* (present only on 25 August), N. V. Belov (absent on 25 August), A. A. Chernov* (present only on 25 August), A. A. Katsnelson* (present only on 25 August), T. I. Malinovsky (absent on 25 August), R. P. Ozerov* (present only on 22 and 25 August), S. A. Semiletov (absent on 25 August), R. Shibayeva* (present only on 25 August), Y. Struchkov (absent on 22 and 25 August), B. K. Vainshtein (absent on 25 August).

Yugoslavia (1): B. Kamenar.

The delegate from Portugal was admitted to the General Assembly after the application from the Portugese Physical Society for membership of the Union had been accepted at the first session of the Assembly on 17 August.

Present as members of the Executive Committee: N. Kato (President), A. J. C. Wilson (Vice-President), S. E. Rasmussen (General Secretary and Treasurer), F. R. Ahmed, E. F. Bertaut, J. Karle, H. Neels, S. Ramaseshan and V. I. Simonov (Ordinary Members). A. Magnéli (Immediate Past President) was unable to attend owing to illness. J. N. King (Executive Secretary) was also prevented by illness from attending. D. W. Penfold (Technical Editor) was in attendance as acting Executive Secretary.

\section{First Session, Monday 17 August 1981, 7.00 p.m.}

\section{(1) Introductory remarks by the President}

Professor KATO welcomed the delegates and observers. He noted that the Union was facing several problems and he asked for constructive discussion. The President also reported that the Executive Secretary, Dr J. N. King, was absent through illness and that Dr D. W. Penfold would be taking his place at the sessions of the General Assembly.

\section{(2) Procedural matters}

In order to verify the list of voting delegates, the President requested the General Secretary to read this list, and asked delegates to indicate their presence when their names were called. (This procedure was repeated at the beginning of each session of the General Assembly.)

Two delegates, M. S. Ahmed (Egypt) and L. Zsoldos (Hungary) were appointed to act as tellers when votes had to be counted during the Assembly.

\section{(3) Approval of Agenda}

The Agenda and the Appendices to the Agenda had been distributed to Secretaries of National Committees on 4 June 1981. An additional Appendix to the Agenda on the In-house Computerized Typesetting system was distributed to Secretaries of the National Committees on 9 July 1981. These Agenda were now approved by the delegates. An additional item was added to the Agenda on 18 August (see Minute 23).

\section{(4) Application for membership of the Union}

An application from the Sociedade Portugesa de Fisica (Portugese Physical Society) had been received by the General Secretary in August 1980 and the General Secretary reminded delegates that details had been distributed with the Agenda papers. A provisional National Committee for Crystallography had been formed with the following membership: Professor L. M. Alte da Veiga (Chairman), Professor M. Margarida R. R. Costa (Secretary), Dr M. Ondina V. de Figueiredo, Dr J. Lima de Faria, Professor 
R. A. Quadrado. The Sociedade Portuguesa de Física wished to adhere in Category I. The Executive Committee has considered the application and recommended to the General Assembly that the Society be accepted as an Adhering Body in Category I. The application was accepted unanimously and Professor L. M. Alte da Veiga joined the Assembly as the delegate of the Society.

\section{(5) Replacement of an Adhering Body}

The General Secretary had been informed that the Suomalainen Tiedeakatemia (Finnish Academy of Science) wished to be replaced by the Suomen Tiedeakatemiain Valtuuskunta (Delegation of the Finnish Academies of Science and Letters) as the Adhering Body representing the crystallographic community in Finland. Professor K. V. J. Kurki-Suonio explained that there had been a reorganization within the Finnish scientific community and the Delegation of the Academies of Science and Letters had been established. It was felt that this Body would be the appropriate Adhering Body to the Union. The Category of Adherence would remain unchanged at Category I. The Delegation had formed a National Committee for Crystallography with the following membership: K. V. J. Kurki-Suonio (Chairman), V. Hovi, V. Lindroos, A. Pajunen, Th. Sahama, P. Suortti, L. Tahvonen. The change was approved by the General Assembly.

\section{(6) Approval of the Minutes of the Eleventh General} Assembly

The Minutes were approved and two copies were signed by the President and the General Secretary, in accordance with By-Law 1.13. There were no matters arising from the Minutes.

\section{(7) Report of the Executive Committee}

The Report of the Executive Committee on the activities of the Union since the Eleventh General Assembly had been submitted to the National Committees and the Commissions in June 1981, in accordance with Statute 6.8, and this follows these Minutes as Annex I, Appendix A. The report was accepted without discussion.

\section{(8) Financial Report}

A Financial Report, covering the calendar years 1978, 1979 and 1980, had been prepared by the Treasurer and had been submitted to the National Committees and the Commissions in June 1981. The Report follows these Minutes as Annex I, Appendix B. A further Appendix, concerned with the next item on the Agenda, the establishment of an in-house computerized typesetting system, was circulated in July 1981 and follows these Minutes as Annex I, Appendix C. The Treasurer referred to both of these Appendices in his comments on the Union finances over the last triennium.

The Treasurer noted that 1978 and 1979 had been satisfactory years, but that a heavy loss had been sustained in 1980. The largest part of this loss occurred on the Acta Crystallographica account and resulted from the large change in exchange rates between the Danish krone and the US dollar and the pound sterling. In order to avoid a repetition of this situation, the Treasurer had obtained quotations in Danish kroner for 1982 (albeit from British printers). He was concerned, however, at the continuing drop in the number of subscriptions to Acta Crystallographica, particularly when taken in relation to the number of pages published, which was not decreasing. Although a similar loss could be expected in 1981, as the largest fluctuations in exchange rates had occurred after the prices of the journals for 1981 had been fixed, the Treasurer hoped that the new quotation procedure, taken in conjunction with a significant price increase in 1982, would avoid a future repetition. Furthermore, because it had been necessary to dispose of a large proportion of the Union's reserves in early 1981 to offset these losses, as described in Annex 1, Appendix C, increases in journal prices would be necessary to build up these reserves again. In future it would be necessary to keep the prices of the journals directly related to production costs in order to keep pace with inflation.

The situation with the other publications of the Union was more satisfactory. The Journal of Applied Crystallography $(J A C)$ was printed in Denmark and therefore the fluctuations in exchange rates had not had the same dramatic effect as on the Acta Crystallographica account. However, the cost of production in Denmark was significantly higher than in the UK and therefore the Treasurer was contemplating moving the production of $J A C$ to England, although quotations would be obtained in Danish kroner. The positions of Structure Reports and International Tables were reasonably satisfactory, as described in Annex I, Appendix B. The Treasurer did however apologize for the long time for which Vol. I of International Tables had been out of print. He hoped that Vol. A of the new series would be available shortly. Sales of the smaller publications were continuing at their previous levels. Royalties on the Japanese edition of Symmetry Aspects of $M$. C. Escher's Periodic Drawings had produced significant income for the Union.

The Treasurer described the operation of the President's Fund. He thanked those who had made donations to the fund and noted that it had already been used to help individual crystallographers when they had found themselves in difficult situations.

Finally the Treasurer commented on the operation of the General Fund. He noted that this had in part been financed over recent years by the redemption of bonds and interest on investments. As it had been necessary for many of the investments to be sold to cover the losses on Acta Crystallographica and also with a view to paying for the in-house typesetting unit, the remaining funds of the Union were almost entirely on deposit with banks in the UK. This did mean that the funds were not quite so vulnerable to fluctuations in exchange rates. The Treasurer referred delegates to the Appendices concerning this item on the Agenda and indicated that he would answer questions.

In answer to N. N. SAHA (India), the Treasurer noted that the donation to International Tables in 1978 was from the French Government as a contribution towards the production costs of the first volume of the new series.

D. M. Blow (UK) drew attention to the increase in the administration costs in the General Fund from 1978 to 1980. The Treasurer said that most of this increase could be attributed to the decrease in value of the US dollar, which is the currency of the account, relative to the pound sterling, in which the administration costs were mainly incurred. In addition there had been a move to new offices in 1979 , which had involved some expenditure; there had been no increases in administrative staff. 
T. I. MALINOvSKY (USSR) asked how many of the Union staff are involved in administration. The Treasurer indicated only the Executive Secretary and his secretary. Furthermore, part of the administrative expenses is attributed to the journal accounts, as are all of the technical editing costs.

The Financial Report was accepted unanimously and, in accordance with Statute 5.10(i), the Treasurer and any other Officer or Chairman of a Commission were released from financial or other liability to the Union.

\section{(9) Establishment of an in-house computerized typesetting system}

Referring to the Appendix to the Agenda, which is printed as Annex I, Appendix $\mathrm{C}$ to these Minutes, the Treasurer described the background to the investigation into the establishment of an in-house typesetting facility. With the increase in typesetting costs in the late 1970's and the advances in typesetting technology, based on microcomputers, which made in-house setting of the complicated mathematics in the IUCr journals a possibility, it seemed reasonable to the Executive Committee, on the basis of a feasibility report produced by the Sub-Committee on In-House Composition, to invest in such a typesetting system rather than in gilt-edge stock. By early 1981 most of the arrangements for setting up the facility had been made. However, the losses on the Acta Crystallographica account in 1980 had affected the Union's cash-fiow situation and therefore the Treasurer had considered abandoning the project. At that time, however, the vendor of the system had suggested payment over a three-year period and, with this in view, the Treasurer and President had looked for various ways in which the money could be obtained to purchase the system. Guarantees had been obtained from the Union's publishers, Munksgaard and Reidel, as well as from one of the Union's Bankers. The Japanese Crystallographic Community had very generously made a large donation and, in view of these arrangements, the Treasurer had remained undecided for several months. He had tried to safeguard the situation and find extra finance, but a downward trend in the number of manuscripts submitted had become apparent and this factor, in addition to the financial factors, had cast doubt on the possible financial success of the project, for if the number of papers submitted became smaller, the assumptions of the feasibility study no longer applied. Furthermore, because of the recession in the United Kingdom, the printer had reduced his typesetting prices, so that the in-house option became less favourable. In this situation, the Treasurer had decided to advise the President not to go ahead with the project.

As it had now been possible to obtain quotations from British printers in Danish kroner, the Treasurer had decided to continue with the conventional procedures for producing the journals. It would, however, be necessary to increase subscription prices significantly in 1982, not only to ensure a reasonable cash flow in 1982, but also to cover at least part of the deficits of $1980 / 81$. While the independence and control which would have been possible with an in-house typesetting facility had its attractions, it was more important for the financial viability of the Union to remain sure.

The President thanked the Treasurer for his summary and asked for questions. R. A. Young (USA) asked what the final recommendation would be. The Treasurer replied that, if the number of manuscripts submitted continued to decline, in-house composition would probably not be the solution. Whereas with a commercial printer, the typesetting cost is related directly to the number of manuscripts, with an in-house facility there is a basic cost which is incurred irrespective of the number of manuscripts. Professor Young wondered whether it would be possible for a system to be used on other Union publications and M. M. WOOLFSON (UK) asked what spare capacity there was likely to be on the system which had previously been chosen. The Treasurer replied that there were various ways of assessing the capacity and various other options and ways in which a computer could be used in Chester. The new Executive Committee and any Finance Committee which was set up by the new Executive Committee would probably be looking into ways in which such operations in Chester could be facilitated. As far as putting other publications onto the system was concerned, the Treasurer felt that handling the journals was a large enough job at the present time, but in theory there was no reason why other publications should not be set on the system.

Finally the Treasurer said how much he appreciated the work done by the staff in the Chester office. Unfortunately the strain involved had been partly responsible for Dr King's illness, but the Treasurer was grateful to both Dr King and Dr Penfold for their efforts over the past year; consideration of the project had involved them in work which far exceeded that required by their terms of reference, both in man hours and in their respective fields of work.

\section{(10) Reports of the Commissions}

The reports of the Commissions and their activities since the Eleventh General Assembly had been distributed to the National Committees and the Commissions in June 1981, in accordance with Statute 8.4. They are reprinted as Annex I, Appendix D to these Minutes; the Statutes and By-laws are printed as Annex II to these Minutes. The reports were taken as read, but the Chairman of each Commission, or his substitute, was invited to say a few words about any further developments and to answer any questions. These verbal reports are summarized in Minutes 11-22. The reports on the Commission on International Tables and on the Commission of Crystallographic Studies at Controlled Pressures and Temperatures were deferred until the meeting on Tuesday 18 August (Minutes 26 and 27).

\section{(11) Commission on Journals}

The Chairman of the Commission and Editor of Acta Crystallographica, S. C. Abrahams, reported that the Commission had met for over three days immediately prior to the General Assembly and had considered all aspects of editorial procedure and policy. The Commission had made the following recommendations to the Executive Committee:

1. That the Executive Committee authorizes the installation of in-house keyboarding facilities, with the typesetting carried out by a commercial printer; this to be an interim step towards full in-house composition, if the full measure is not possible at the present time.

2. That the Executive Committee investigates with all possible speed the steps required for the Union to become its own publisher. 
With reference to recommendation 1 , the Commission felt that in the long term in-house composition would be the only way of keeping the production costs of the journals to a reasonable minimum. Such a move would also make it possible for the Union to move gradually into the area of electronic communication and take advantage of other advances in technology. With reference to recommendation 2 , the Commission felt that the sum of approximately $\$ 100000$ per year which was paid to publishers as a commission could hopefully be saved, at least in part, by the Union undertaking its own publishing. Dr ABraHams noted that there could be problems involved in the Union taking on the publishing role, but the Commission would like the Executive Committee to investigate such problems.

With reference to the Union taking the step proposed in the Commission's second recommendation, D. M. BLow (UK) noted that the Treasurer had mentioned the setting up of a Finance Committee and wished to know how this would affect the operation of the Union and when it would be discussed by the General Assembly. If the IUCr were to become involved in publishing, it would have an effect upon the employees and on the Union's capital investment. This should not be implemented without a report to the General Assembly. The Treasurer said that the proposed Finance Committee would be a sub-committee of the Executive Committee to advise the General Secretary and Treasurer. $\mathrm{He}$ hoped that further information would be provided at a later session of the General Assembly. Dr ABRAHAMs emphasized that the Commission on Journals was not proposing that the Union carry out its own publishing, only that an investigation of the possibilities should be carried out.

A. Authier (France) asked if, in view of the fall in both the number of subscriptions and the number of manuscripts, the Commission was giving consideration to possible changes in content and format of the journals. Dr ABRAHAMS noted the proposed division of Section B of Acta Crystallographica and the merger with Crystal Structure Communications and referred Professor Authier to the Open Meeting of the Commission later in the week. Further discussion was concerned not so much with activities of the Commission on Journals, but with the way in which the second recommendation of the Commission could be handled. The question of the proposed Finance Committee was again raised and R. A. Young (USA), A. AUTHIER (France), G. A. JefFrey (USA), G. S. D. King (Belgium), D. M. Blow (UK) and S. Abrahamsson (Sweden) felt that any proposal for the setting up of a Finance Committee and any changes in the governance of the Union should be considered by the General Assembly. On the other hand, F. W. B. EinsteIN (Canada) and E. N. MASLEN (Australia) felt that, as a Finance Committee would be a sub-committee of the Executive Committee, it was not a concern of the General Assembly and the General Assembly should be careful not to pass such resolutions as would make it impossible for the Executive Committee to carry out its job effectively. The Treasurer noted the comments that had been made and said that more details on the Finance Committee and its composition would be made available once the elections had been held.

The Co-Chairman of the Commission and Editor of Journal of Applied Crystallography, M. HART, had nothing further to report. A vote of thanks to all retiring editors was passed unanimously.

\section{(12) Commission on Structure Reports}

The Chairman of the Commission and Editor of Structure Reports, J. TrotTER noted that Professor G. Ferguson would be taking over from him as General Editor of Structure Reports, subject to the approval of the General Assembly.

G. S. D. KING (Belgium) asked if the Commission had considered input of computer data input from computer databases, so that the information given in Structure Reports would be available more quickly. If so, how would this affect the future policy for Siructure Reports? Professor TROTTER replied that the Commission had considered the problem and were considering whether all of the sections were any longer necessary in view of the databases now available. L. D. CALverT (Canada) commented that many people found books much easier to handle than on-line terminals. E. F. BERTAUT noted that there were ten times as many organic papers as inorganic papers, but that it was important to be able to locate reports of significant structures.

\section{(13) Commission on Charge, Spin and Momentum Densities}

The Chairman of the Commission, K. V. J. KURKISuonio, had nothing to add to his report and there were no questions.

\section{(14) Commission on Crystal Growth}

The Chairman of the Commission, E. KaLDIS, noted that the Commission was proposing a change in name which would be considered later during the General Assembly. The Commission would have advised a more drastic change, but it was felt wise to keep the words 'Crystal Growth' in the name of the Commission.

\section{(15) Commission on Crystallographic Apparatus}

The Chairman of the Commission, S. ABrahamsson, noted that four of the projects described in his report had been completed, two were still under way and the Commission was contemplating two or three more.

\section{(16) Commission on Crystallographic Computing}

The Chairman of the Commission, R. Diamond, reported that the recommended format for interchange of structural data had been agreed by the joint working party of the Commissions on Crystallographic Computing and Crystallographic Data. This would now be submitted to the Commission on Journals with a view to publication. Dr Diamond hoped that it would find acceptance amongst crystallographers in general.

M. M. WoOLFSON (UK) reported that the computing school held immediately before the Congress had been outstandingly successful, mainly owing to the efforts of the organizers, D. Sayre, R. Diamond and F. R. Ahmed.

J. BERNSTEIN (Israel) reported that some of G. M. Sheldrick's trial structures were now available from him, while the remainder would be available in due course.

The Treasurer noted that the book Computing in Crystallography, the report of the winter school held in Bangalore in January 1980, was on display at the book stall. This had been published by the Indian Academy of Sciences on behalf of the Union. Orders could be placed at the Congress. 


\section{(17) Commission on Crystallographic Data}

The Chairman of the Commission, D G. WATSON, said that he also wished to draw attention to the report on the data exchange format produced by the joint working party with the Commission on Crystallographic Computing. Professor G. A. JefFrey reported that the efforts of the Co-editors of Acta Crystallographica had reduced the published errors in Acta to only $6.5 \%$ of published papers. However, Professor JefFrey noted that there were still errors in $35 \%$ of the manuscripts he received and the rate appeared to be increasing. He urged authors to reverse the trend.

\section{(18) Commission on Crystallographic Nomenclature}

The Chairman of the Commission, S. C. Abrahams, noted that the report of the ad-hoc Committee on the Nomenclature of Disordered, Modulated and Polytype Structures had been received and would be discussed later during the Congress. The other ad-hoc Committee on the Nomenclature of Symmetry would report at the next Congress.

The President reported with regret that an active member of the first of these ad-hoc committees, Professor $\mathrm{K}$. Boll-Dornberger, had recently died.

\section{(19) Commission on Crystallographic Teaching}

The Chairman of the Commission, A. AUTHIER, noted that plans were under way for the next summer school, to be held in Brazil. He added that the first set of teaching pamphlets had been very successful and 3000 copies had been sold.

E. N. MAslen (Australia) asked if there would be any benefit in integrating the activities of the Commission with those of the Commission on Crystallographic Computing. Professor AUTHIER said that, although there had been no joint projects with the Commission on Computing, the last summer school had been held in conjunction with the Commission on Crystal Growth.

A. VACIAGo (Italy) thought that the General Assembly would be interested to note that Professor T. Blundell had been appointed as the new Director of the Ettore Majorana Centre at Erice, Sicily. This appointment was from 1981 until 1984.

\section{(20) Commission on Electron Diffraction}

In the absence of the Chairman, P. Goodman, D. WATANABE reported. He said that he hoped that the book edited by Dr Goodman, Fifty Years of Electron Diffraction, would be exhibited during the Congress, if copies delayed by the Canadian mail strike had arrived.

\section{(21) Commission on Neutron Diffraction}

The Chairman, D. E. Cox, reported that a very successful symposium had been held on neutron scattering at Argonne National Laboratory immediately before the Congress.

R. A. YounG (USA) said that as it had been reported that two of the three satellite meetings had been successful, he would like to report that the third, on Crystallography in the Health Sciences, held in Toronto, had also been a great success.
(22) Determination of the number of elected members of each Commission

In accordance with Statute $5.10(d)$, the Assembly had to determine the number of persons to be elected on the Commissions until the Thirteenth General Assembly; these numbers did not include Chairman or ex officio members.

A. J. C. WILson moved that the number of elected members of each individual Commission should remain the same as previously. [The General Secretary noted that there was a misprint in the Agenda papers and that the number of elected members of the Commission on Crystallographic Studies at Controlled Pressures and Temperatures should be 8 and not 6.] A. PODJARNy (Argentina) agreed with Professor Wilson's proposal, unless any Chairman of a Commission wished to change the number of elected members in the Commission. No Commission Chairman proposed a change and the proposal was agreed unanimously. The General Secretary reported that the slate proposed by the Executive Committee for the Membership of Commissions would be posted in time for election at the session of the General Assembly on 22 August. The numbers of elected members approved by the General Assembly (Chairman not included) are set out below:

1. Commission on Journals

2. Commission on Structure Reports

3. Commission on International Tables 0

4. Commission on Charge, Spin and Momentum Densities

5. Commission on Crystal Growth

6. Commission on Crystallographic Apparatus

7. Commission on Crystallographic Computing

8. Commission on Crystallographic Data

9. Commission on Crystallographic Nomenclature

10. Commission on Crystallographic Studies at Controlled Pressures and Temperatures

11. Commission on Crystallographic Teaching

12. Commission on Electron Diffraction

13. Commission on Neutron Diffraction

The President then adjourned the session at 9.40 p.m.

\section{Second Session, Tuesday 18 August $1981,7.08$ p.m.} (23) Addition to the Agenda

The General Secretary reported that the Executive Committee wished to add a further item to the Agenda. This was A charge for publishing? A memorandum concerning this had been circulated to delegates. The intention was purely to discuss the question so that the Executive Committee could be aware of the opinions of delegates. There would be no decision on the matter at the present General Assembly. With one objection, it was agreed to add this item to the Agenda.

\section{(24) Confirmation of the date and place of the Thirteenth} General Assembly

At the President's request, K. FISCHER (Federal Republic of Germany) formally confirmed the invitation of the Arbeitsgemeinschaft Kristallographie for the Thirteenth General Assembly and International Congress of Crystallography to be held at Hamburg, Federal Republic of Germany, 9-18 August 1984, as presented by Professor H. Schulz and 
accepted by the Eleventh General Assembly in Warsaw in 1978. If the invitation were accepted, the Congress would be held at the Congress Centre of Hamburg. This was close to the city and the University, as well as being convenient for DESY (Deutsches Elektronen Synchrotron). Professor Fischer said that Professor H. SAAlfeld of the University of Hamburg, who was the designated Chairman of the Organizing Committee, would be willing to answer any questions.

R. A. Young (USA) asked if possible clashes with the congresses of other Unions had been taken into account in view of the overlap between the present Congress and that of the International Union of Biophysics in Mexico City. J. KARLE replied that whenever the information was available every effort was made to avoid conflicts of dates. In this connection M. M. WoOLFSON (UK) asked if the Secretariat of the International Council of Scientific Unions (ICSU) keep a calendar of events and suggested that if they did not, then one should be considered. The President replied that the ICSU Yearbook contained dates of meetings and the Executive Secretary had already submitted the proposed dates for the 1984 Congress. The General Secretary confirmed that the ICSU Secretariat tries to keep up to date with information, but it is the responsibility of the individual Unions to pass on this information. D. BLow (UK) asked if the 1984 date could be passed onto the International Union of Biophysics, which was meeting the following week.

G. A. JEFFrey (USA) asked the Executive Committee to reconsider the length of future Congresses. H. Schulz (Federal Republic of Germany) replied that it was unfortunately too late to change the dates of the Hamburg Conference, which had been fixed at the request of the Eleventh General Assembly in Warsaw. He suggested that this should be discussed for future Congresses.

A. Authier (France) emphasized that if young people were to attend the Congress, they would need cheap accommodation. Professor SAALFELD said that the Organizing Committee would do their best to meet this requirement.

The invitation from the Arbeitsgemeinschaft Kristallog raphie of the Federal Republic of Germany was accepted with acclamation.

\section{(25) Establishment of Finance and Long-Range Planning Committees}

The President asked the Vice-President, A. J. C. WILson, to explain the Executive Committee's proposals.

Professor WILSON first emphasized that the proposals had been formulated by the present Executive Committee and were in no way binding on the new Executive Committee. who would have the responsibility of implementing them. It was proposed that two sub-committees of the Executive Committee, a Finance Committee and a Long-Range Planning Committee, be established.

Professor WILSON reported that the proposed terms of reference of the Finance Committee were as follows:

1. The Finance Committee (FC) and its Chairman would be appointed by the Executive Committee (EC) to advise on finances, establishment and salaries. The FC would report to the EC through the Treasurer.

2. The activities of the FC would comprise the following major functions:
I. Conduct of regular business:

(a) Development of a thorough and detailed knowledge of the financial and administrative arrangements of the Union.

(b) Monitoring of the finances, investments, cash flow and manuscript flow. Part of the monitoring would be supervision of the countersigning of cheques and other financial documents relating to substantial non-routine transactions.

(c) Having received from the Executive Secretary monthly reports on income and expenditure of Union activities and monthly statements about the flow of manuscripts through the Union office, the FC would report quarterly to the Executive Committee and more frequently if it considered this to be necessary.

(d) The FC would make recommendations for subscription prices and other prices for $\mathrm{IUCr}$ publications and for short-range adjustments to the flow of business.

II. Union office:

The FC should review annually salaries of and pension arrangements for the $\mathrm{IUCr}$ employees, establishment, premises and insurance.

An appropriate membership would be the following:

1. Secretary-Treasurer

2. President or Vice-President

3. Chairman of the Commission on Journals

4. UK member of Executive Committee if there is one

5. One or two UK crystallographers so that the number on the FC is at least two.

The Executive Secretary would act as Secretary of the FC, but may be asked to withdraw during discussions of establishment and salaries. The Technical Editor would attend meetings as necessary.

The FC should seek expert financial advice as necessary.

Normally the FC would meet immediately before the yearly EC meeting and a second time during the year. Additional meetings would be held, if necessary.

The new Finance Committee would take over the work of the Staff, Establishment and Salaries Committee which could therefore be discontinued.

D. M. BLow (UK) asked if the only action of the Finance Committee would be to report to the Treasurer. Professor WILson replied that the Finance Committee could report to the Executive Committee through the Treasurer and indeed it would be difficult for it to withhold this report. Its main function would, however, be to monitor the Union's operations and report on these. Professor BLow further commented that it appeared that the Committee had no powers which the Treasurer and General Secretary did not have already. Professor WILSON confirmed this and said that the Executive Secretary would report monthly to the Finance Committee, which would in turn report quarterly, or more frequently if necessary, to the Executive Committee. Therefore reports to the Executive Committee of any unforeseen changes in the Union's cash-flow situation would be subject at most to a two-month delay. E. N. MASLEN (Australia) asked if the Finance Committee would have power to consult and co-opt. Professor Wilson said that it would have power to consult, but not to co-opt. N. N. SAHA (India) asked if the Finance Committee would be concerned just with the 
publications or with all the financial aspects of the Union. Professor WiLson answered that it would be involved with all short-term financial operations of the Union except the operation of the President's fund. In reply to $M$. M. Woolfson (UK), Professor WILson said that the Treasurer has power to act on his own authority in a crisis, without consulting the Executive Committee, but the establishment of the Finance Committee was likely to speed up such decisions, rather than the reverse. In answer to N. N. SAHA (India), the Vice-President said that the whole Executive Committee is responsible for any decision, but in the case of routine decisions, this power is delegated to the General Secretary and Treasurer, who would now have a larger base to consult. R. A. Young (USA) questioned the division of authority between the President and the General Secretary and Treasurer. Professor WILsON said that philosophically the President had the greater power, but, according to the statutes, the General Secretary and Treasurer is responsible for conducting the ordinary business of the Union; in practice the President has great influence and would be consulted.

Professor WILson then reported that the proposed terms of reference for the Long-Range Planning Committee were as follows:

1. The Long-Range Planning Committee (LRPC) and its Chairman would be appointed by the Executive Committee (EC) to advise on the future development of the Union, particularly with respect to the production and dissemination of scientific information.

2. The LRPC would report to the EC through its Chairman. The membership would be:

1. President

2. Vice-President

3. Secretary-Treasurer

4. An additional member of the EC

5. Chairman of the Commission on Journals

6. Representatives of the Union on the ICSU Abstracting Board

Professor WILSON noted that nothing was said about the frequency of meeting or of reporting and that this would be up to the Executive Committee or the Long-Range Planning Committee itself. A. VACIAGo (Italy) asked if this was to be a steering committee of the Executive Committee. Professor WILSON said that this was not the intention; the Executive Committee is its own steering committee, while the LongRange Planning Committee would look at possible future developments in the long term. G. AlLegra (Italy) asked if the bureaucratic structure might become too complicated. Could the Finance and Long Range Planning Committees be combined? Professor WILSON said that the Union was one of the few organizations without a Finance Committee. H. WONDRATSCHEK (Federal Republic of Germany) commented that one would expect to have on the Finance Committee members, who were not members of the Executive Committee, but who were experienced in financial areas; and Professor WILson said that it was intended that the second UK member should be chosen for just these reasons and that further expert advice would be sought as necessary. Professor WondRatscheK also wondered if such a member was necessary on the Long-Range Planning Committee. Professor Wilson, answering both Professor WondratscheK and Professor Allegra, replied that the
Long-Range Planning Committee was not concerned with investments and was concerned with the overall work of the Union, rather than its financial strength.

A. VACIAGO (Italy) thanked the Executive Committee for its explanation, which he felt had allayed any anxiety felt by delegates during the previous session of the General Assembly.

\section{(26) Commission on International Tables}

The Chairman, $T_{H}$. HAHN reported that the space group tables for the new volume on direct space were in proof and would be on display at the Congress. He would be happy to receive ideas or suggestions. He hoped that the printing would take place in the near future.

J. GLUSKER (USA) asked whether Vol. I of the old series would be reprinted. The Treasurer replied that the intention was to replace it with the new volume. He was aware that the new volume did not contain structure-factor tables but he would ask the new Commission on International Tables to look at the matter. He regretted that he had underestimated the demand for Vol. I when setting the size of the reprint order.

\section{(27) Commission on Crystallographic Studies at Con- trolled Pressures and Temperatures}

The Chairman of the Commission, S. АкIмото, said that the reports of the projects carried out by the Commission would be given at the Open Meeting of the Commission later in the week. He had nothing else to add to his report.

\section{(28) Change of name of the Commission on Crystal Growth}

The Chairman of the Commission, E. KALDIS, reported that the Commission had proposed to the Executive Committee that its name should be changed to the Commission on Crystal Growth and Characterization of Materials, since it was expanding its scientific interests into the field of materials research related to crystal growth. For example, the Commission, in conjunction with the Commission on Crystallographic Teaching, had organized the Sixth Course of the International School of Crystallography entitled 'New Crystallographic Perspectives in Materials Science', which was held at Erice in April 1980, whilst an International Summer School on Synthesis, Crystal Growth and Characterization of Materials for Energy Conversion and Storage would be held in New Delhi, 12-23 October 1981.

Professor Kaldis considered that the influence of synthesis and growth properties on the other properties of crystals had become very important, and should be included in the fields of interest of the Commission. Until recently crystallography had been mainly confined to structure determinations, a field which was extremely important but was not generally appreciated by industry, and major research institutions were not employing as many crystallographers on their staff as should be the case. He proposed that the interests of the Union and the Commission should be expanded to include applied and industrial research relating to the characterization of materials.

Professor KALDIS also pointed out that the change of name would also lead to a wider area in which grants could be obtained for possible projects. The President emphasized that part of the aim was to widen the field of both the Commission and the Union as a whole. E. HOEHNE (German 
Democratic Republic) suggested the name Crystal Growth in Materials Science, but G. S. D. KING (Belgium) felt that this would be a limitation on the work of the Commission. He suggested that the Commission's proposal should be accepted, as it was with a large majority.

\section{(29) Establishment of a Commission on Biological Macro-} molecular Crystallography

J. KARLE introduced discussion on this topic. He noted that in the USA there had seemed to be division between macromolecular crystallography and the rest of crystallography, with very few macromolecular crystallographers attending general crystallographic meetings and vice versa. The American Crystallographic Association had recognized the value of special interest groups and had set up one on macromolecular crystallography. This had worked well and had created a group to act as spokesman for this particular area and also to organize meetings and symposia at the American Crystallographic Association Meetings. This led to the airing of problems specific to this group as well as to increased interaction with other crystallographers.

Therefore, in order to extend this process on an international scale, the USA National Committee for Crystallography (NCCr) had, in April 1980, submitted a resolution to the Executive Committee for the establishment of a new Commission. It noted that, whilst the present effort in biological macromolecule crystallography was large and important, it was highly under-represented at current and past International Congresses of Crystallography. It was considered desirable to bring members of the biological macromolecule crystallographic community more closely into the primary activities of the IUCr. It therefore urged the Executive Committee and the General Assembly to take appropriate action under Statute $5.11(c)$ to set up a Commission on Macromolecule Crystallography, and to determine its terms of reference.

The Executive Committee considered the proposal in July 1981 and had recommended to the General Assembly that such a Commission be established. It had asked the USA $\mathrm{NCCr}$ to assist it in determining draft terms of reference for the Commission, for consideration by the General Assembly.

The USA NCCr had suggested the following draft terms:

1. To advise the $\mathrm{IUCr}$ in organizing or sponsoring sessions on macromolecular crystallography at Congresses and conferences.

2. To promote and co-ordinate scientific exchange between countries in the field of macromolecular crystallography.

3. To cooperate with other Commissions of the Union on matters dealing with macromolecular crystallography.

4. To cooperate with other international bodies interested in macromolecular crystallography and allied subjects.

The USA NCCr also suggested that the Commission should consist of not more than six members. The British and Italian delegates indicated their support for this proposal.

B. K. VAINSHTEIN (USSR) asked if only biological molecules were to be considered or if other large molecules such as polymers would also be included within the scope of the Commission. At Dr KARLE's request, R. A. YounG (USA) explained that in the USA the interest had arisen amonst protein crystallographers, partly because of the small proportion of protein work considered at the International
Congresses in Amsterdam and Warsaw. S. C. ABraHAms (USA) added that the intention had been that this should be a Commission concerned with biological macromolecular crystallography. There followed some discussion on whether the name of the Commission should be 'Biological-Macromolecule Crystallography' or 'Biological Micromolecular Crystallography'. The final decision was left to the Executive Committee. There was however unanimous support for the establishment of the Commission with the terms of reference proposed by the USA National Committee.

The General Secretary reported that, although the USA National Committee had suggested that the Commission should consist of not more than six members, discussions between the Executive Committee and those who were interested in forming the Commission had indicated that eight plus the Chairman would be appropriate. It was agreed that the membership should be as recommended by the Executive Committee.

R. Diamond (UK) asked that the Commission be requested to make use of Acta Crystallographica for publications in the field of its concern; most publications in this area were sent to other journals at present.

\section{(30) Reports of the Representatives on Scientific and Regional Associates}

In accordance with Statute 8.5 the reports of the representatives on Scientific and Regional Associates had been submitted to National Committees and Commissions in June; they are printed as Annex I, Appendix E to these minutes. The reports were taken as read. Neither the representative on the International Organization for Crystal Growth nor the representative on the European Crystallographic Committee had anything further to add and no questions were asked by the delegates.

\section{(31) Reports of the Representatives on Bodies not belonging to the Union}

In accordance with Statute 8.5 the reports of the Representatives on bodies not belonging to the Union had been submitted to the National Committees and Commissions in June; they are printed as Annex I, Appendix F to these minutes. The reports were taken as read, but the representatives were invited to inform the Assembly of any further developments (see Minutes 31-34).

The representatives on the IUPAP Commission on the Solid State, the Conference Committee of the European Physical Society, the ICSU Committee on Data for Science and Technology (CODATA), the ICSU Committee on Teaching of Science, and ICSU Scientific Committee on Problems of the Environment (SCOPE) had nothing further to add and were not asked any questions by the delegates.

\section{(32) ICSU Abstracting Board}

A. J. C. WILSON reported that the Board had recently met in Georgia, USA. In 1982 there would be a symposium in Amsterdam on 'The Role of Information in the Innovative Process'. S. C. Abrahams (USA) asked for information on the possibility of a publishers' consortium working in conjunction with the British Library Lending Division. Professor WILsON reported that the intention was to make it possible for readers to obtain quick back-up material for information obtained from abstracts or databases. The copy from the British Library Lending Division would be 
transmitted by facsimile transmission. The prime mover in this project was the Elsevier Group, and it had been claimed that the quality produced would be good enough for the transmission of half-tones. So far ten publishers had expressed interest. The cost would probably be high in order to cover publishers' royalties. The British Library had as yet given no commitment on the project. It was likely that the cost would be considerably higher than the $\$ 1.00$ which had been reported in certain areas. Dr ABRAHAMS confirmed that $\$ 1.00$ had been the figure quoted at the American Institute of Physics, and he was concerned that if this proposal did become a reality, there would be a significant effect on the publication of scientific journals. Professor WILsON agreed and said that perhaps the $\$ 1.00$ figure covered only the royalty and not the transmission and copying costs.

\section{(33) ICSU Committee on Science and Technology in Developing Countries (COSTED)}

A. AUTHIER said that there was a hope that relations between COSTED and the individual Unions would be strengthened. In addition, support from COSTED would in future be more geographically wide spread.

\section{(34) ICSU Committee on Space Research (COSPAR)}

E. KALDIS reported that there had not been the expected expansion in the work of this Committee, because of the delay in the development of the space laboratory, for which most of the projected experiments had been planned. There had only been discussion of short-term experiments in rockets and none of the results had been very dramatic. It was expected that after twenty years the technology would change dramatically as more possibilities became available. There were soon expected to be developments by the European Space Agency concerned with experiments on space platforms.

\section{(35) Sub-committee on the Union Calendar}

A summary of activities of the Sub-committee was distributed with the General Assembly papers in June and is given as Annex I, Appendix $G$ to these Minutes. The Chairman of the Sub-committee, J. KARLE, had nothing further to add to this report.

\section{(36) Consideration of provision for individual scientists to become members of the Union}

S. C. Abrahams reported on the discussions of the Committee set up to discuss this matter, which had not felt that it should make recommendations, but only consider the possible advantages and disadvantages; these are given in Annex I, Appendix $\mathrm{H}$ to these Minutes. The suggestion of individual membership had been linked to the possibility of the Union producing an Abstracts journal containing also news items of interest to individual crystallographers. This, it had been suggested, could be made available to individual members. There had been no suggestion that there should be voting rights associated with individual membership. However, none of the advantages or disadvantages listed in Annex I, Appendix $\mathrm{H}$ was thought to be particularly significant. $\mathrm{Dr}$ Abrahams asked if the General Assembly had any thoughts on the matter or if it wished the Sub-committee to take its considerations any further.
A. Vaciago (Italy) asked which other Unions had individual membership and if these Unions were members of ICSU. Dr ABRAHAMS replied that they were indeed members of ICSU and the principal Union involved was the International Astronomical Union (IAU), which had had individual members since 1913. Those members of the IAU who had been consulted were enthusiastic about this individual membership. The main advantage they saw was the direct communication, by periodic bulletins, between the Secretariat and all astronomers in the world. The membership is open to all interested, although there is a nomination and recommendation procedure which has to be followed before election. No other Unions have individual membership, although the International Union of Pure and Applied Chemistry is investigating the possibility; no information was available on the progress of their deliberations.

T. SABINE (Australia) wondered whether it was ethical to charge members a fee without giving them corresponding voting rights. B. K. VAINSHTEIN (USSR) asked if individual membership was intended for those whose countries were not members of the Union. Dr ABRahams replied that it would probably be most useful to those in small countries who would otherwise be unaware of the activities of the Union. Professor VAINSHTEIN asked further if there had been any applications for such membership. The General Secretary replied that he had been approached by young crystallographers, in particular, who felt that they would like to belong to the Union. If there were some provision for payment in return for a Newsletter, this would improve communication, especially in areas with little national activity. The General Secretary had also received written statements from individuals in such areas who would like to be associated with the Union. E. N. MASLEN (Australia) said that he could see merits in the proposal, but it should be clearly stated that what was being considered was associate membership for those whose countries did not have an adhering body. A. PODJARNY (Argentina) said that in countries with a small population of crystallographers, communication with the Union tended to be on a very formal basis. He suggested that a Newsletter would be very helpful, particularly to young crystallographers in these countries; it would be a valuable service and was not related to voting at Assemblies and similar procedural aspects. J. BERNSTEIN (Israel) said that the Conference Board of Mathematical Sciences produced a quarterly Newsletter for $\$ 4.00$. This contained information that was not available elsewhere. He asked that the IUCr should consider producing a similar Newsletter. R. A. Young (USA) said that the USA National Committee did not feel that the advantages were compelling enough for it to support the institution of individual membership. M. M. WOOLFSON (UK) said that he was a member of the International Astronomical Union and he did not feel that this was a particuarly valuable comparison, because many of the individual members were amateur astronomers and astronomy was a very different subject from crystallography; there were almost certainly no amateur crystallographers. Professor Woolfson felt that ad-hoc arrangements should be made to cater for the very small numbers of crystallographers in the world who do not have access to information on any other basis. A. AuTHIER (France) agreed and said that, although it was reasonable to help crystallographers in areas with no adhering body and for the Union to distribute a Newsletter, it was not practical for the Union to 
have individual membership. G. A. JEFFREY (USA) noted that governments were always looking for excuses not to spend money and if there were individual members in countries which did adhere to the Union, governments could possibly use this as an excuse for no longer providing the support which they had given in the past. Y. MASCARENHAS (Brazil) said that it was the responsibility of National Committees to keep crystallographers aware of events, but she asked that the IUCr should have a stronger contact with National Committees and provide more extensive information. G. S. D. KING (Belgium), however, noted that there were a number of countries in the current edition of the World Directory of Crystallographers who did not have a National Committee and, however the Union's service to the National Committees was strengthened, these people would not be helped. A. VACIAGo (Italy) underlined the difference between membership and information. He felt that anyone could subscribe to Acta Crystallographica or to a Newsletter if one were produced. He also agreed with the points made by Professors Woolfson and Jeffrey.

The President thanked all delegates for their comments and said that these points would be taken into consideration if there were any further consideration of this question. He then adjourned the meeting at 9.20 p.m.

Third Session, Saturday 22 August 1981, 7.00 p.m. (37) Election of Chairmen and members of Commissions

The nominations made by the Executive Committee for the Chairmen and members of Commissions had been notified to the delegates (and alternates) on 18 and 19 August.

In the absence of other nominations being made by delegates, all persons nominated by the Executive Committee as Chairmen and members of Commissions were considered as elected. According to Statute 7.3, the Editors and Coeditors were automatically members of the Commissions set up for the publications concerned. The Commission on Crystallographic Nomenclature consists of the Editors of Acta Crystallographica, Journal of Applied Crystallography, Structure Reports and International Tables with the firstnamed Editor as Chairman.

The full memberships of the Conımissions including ex officio members, together with the addresses of the Chairmen, are given in Annex III.

(38) Election of Representatives on Bodies not belonging to the Union and on Regional and Scientific Associates

The nominations made by the Executive Committee for those representatives to be elected by the General Assembly had been notified to the delegates (and alternates) on 18 August. As no other nominations had been made by delegates, all persons nominated by the Executive Committee were considered as elected. The names and addresses of the Representatives of the Union, including those appointed ex officio, are given in Annex III.

\section{(39) Election of Officers of the Union}

In accordance with By-Laws 2.2 and 7.1, the nominations made by the Executive Committee for Officers of the Union had been notified to delegates (and alternates) on 17 August. J. Karle had been elected an ordinary member of the Executive Committee at the Eleventh General Assembly, to serve until the close of the Thirteenth General Assembly. In accordance with By-Law 2.2, the Executive Committee had nominated M. M. Woolfson to fill the vacancy created, for the period to the Thirteenth General Assembly, if Professor Karle was elected President. Some of the delegates had made an additional nomination for the office of ordinary member for the full six-year term. This nomination had been submitted in accordance with the procedure specified in By-Law 7.2.

As no counter nominations had been made for the positions of President, Vice-President, General Secretary and Treasurer and Ordinary member (for three years), the following were considered elected:

President: J. Karle (USA)

Vice-President: S. Ramaseshan (India)

General Secretary and Treasurer: K. V. J. Kurki-Suonio (Finland)

Ordinary Member: M. M. Woolfson (UK)

The General Secretary explained the procedure for the election of the three remaining ordinary members of the Executive Committee. There was some discussion on the right of the delegates to cast more than one vote when delegations were not complete. The General Secretary referred delegates to Statute 5.7 which allows the distribution of votes amongst those delegates present. This was agreed to be acceptable. S. Amelincx (Belgium), Th. Hahn (Federal Republic of Germany) and M. Nardelli (Italy) had been nominated by the Executive Committee; S. GarciaBlanco (Spain) had been nominated by delegates. The following were elected to serve as ordinary members of the Executive Committee until the end of the Fourteenth General Assembly: Th. Hahn (68 votes), M. Nardelli (62 votes) and S. Amelincx (42 votes). S. Garcia-Blanco received 38 votes.

K. V. J. KURKI-SUONIO thanked delegates for the honour which they had done him by electing him as General Secretary and Treasurer, thus placing their confidence in him. He said that he would find it very difficult to carry out the role as successfully as had Professor Rasmussen, but that he would do his best. This was greeted with acclaim.

\section{(40) Date and place of the Fourteenth General Assembly}

The President noted that in accordance with By-Law 1.3 the General Assembly could give preliminary consideration to the place of the next General Assembly but one. He asked the General Secretary to speak.

The General Secretary reported that he had received a formal invitation from Professor E. N. Maslen on behalf of the Society for Crystallographers in Australia and the Australian National Committee for Crystallography for the Fourteenth General Assembly and Congress to be held in Australia. The Executive Committee would like to recommend acceptance of this invitation.

N. N. SAHA (India) asked whether an invitation from India had been considered in view of the informal invitation which had been reported in the Agenda papers. Professor RASMUSSEN explained that enquiries had been made as to whether a formal invitation would be forthcoming from the Indian National Committee, but it had been made clear that there would not be one at the present General Assembly. He also emphasized that the Executive Committee had not solicited the Australian invitation. 
Professor MASLEN said that he should make it clear that, although the invitation from Australia was given with the enthusiastic support of Australian crystallographers, it was not supported by government funds and there would be no travel support available. He felt that delegates should be quite clear about this before they accepted the invitation. D. M. BLow (UK) asked where the General Assembly would be held. Professor MASLEN said that no decision had yet been reached on this matter and it would be subject to negotiation. If a strong support were expressed for one particular place, this would be taken into account. In answer to a question from J. BERNSTEIN (Israel), the President said that the place and dates of the Fourteenth General Assembly had to be confirmed by the Thirteenth Assembly meeting in Hamburg.

G. A. JEFFREY (USA) requested that, in view of the response concerning the Thirteenth General Assembly, that the length of the scientific component of the Fourteenth General Assembly should be not more than six continuous days, i.e. two days less than at the Twelfth Congress. F. W. B. Einstein (Canada) suggested that this should be referred to the organizers of the Fourteenth General Assembly, but he urged that a decision be made on the provisional place of the Fourteenth General Assembly as the planning involved required a considerable amount of time. The matter was put to the vote and the invitation was accepted with no votes against.

J. P. Glusker (USA) asked that Professor Jeffrey's request be put as a formal motion, that the scientific content of the Fourteenth General Assembly should not exceed six days. M. M. WOOLFSON (UK) expressed sympathy with this point of view, but noted that people would be travelling a large distance at considerable expense and the opportunity for specialist groups to meet under these circumstances should not be missed. He therefore suggested that although possibly the general programme should only last for six days, specialist groups should be encouraged to meet before and/or after the Congress. W. Eysel (Federal Republic of Germany) asked if Dr Glusker's proposal applied only to the Australian meeting or if it was for all future Congresses. He suggested that it be tried as an experiment for the Australian meeting, as there were likely to be fewer people present than at Congresses in more central countries, and then the matter reconsidered. A. Authier (France) pointed out that if the same scientific content was condensed into a shorter period, then even more parallel sessions would be required than at present. This would mean that there would be a tendency for the Congress to break-up into a series of small meetings and crystallographers in different specialized areas would find it difficult to meet together. R. A. Young (USA) asked that the General Assembly should meet before and after the Congress but not during the Congress as the administrative responsibilities of delegates tended to divert them from scientific matters. Professor JEFFreY supported this view.

A. VACIAGO (Italy) said that he was sympathetic with Professor Young's proposal, but he noted two points: Firstly, people are provided with travelling expenses to attend the General Assembly and not to attend the Congress and, if the General Assembly takes place before or after the Congress, this may affect people's ability to attend the Congress itself; secondly, the General Assembly is a public meeting and therefore the present arrangement of sessions should be retained. These comments received much support from delegates. Professor Young also agreed and he suggested one meeting of the General Assembly before the Congress, one after and, to meet Professor Vaciago's second point, one during the scientific sessions.

The General Secretary noted that as a result of a request from the USA National Committee in 1975, the time between nominations and elections had been extended to give more time for counter-nominations. Also the elections were now being held as early as possible so that new Officers and members of Commissions could meet during the Congress. The new proposal from the USA National Committee to compress the period of the Congress would mean that these time limits would again have to be changed. The General Secretary pointed out that changes to statutes are timeconsuming and difficult operations and that this should also be taken into consideration. He further suggested that $\mathrm{Dr}$ Glusker's motion should be put at the Thirteenth General Assembly.

Professor MASLEN said that he had noted the points raised and the Australian Organizing Committee would take them into account.

\section{(41) Change in the unit of currency for subscriptions}

The Treasurer noted that it had frequently been suggested that, in view of large exchange-rate fluctuations, a more stable currency than the US Dollar should perhaps be considered for the unit of currency for subscriptions. He pointed out that he had noted on several occasions that the percentage increase in the unit contribution would have been smaller had the contribution been expressed in Swiss Francs. Although the US Dollar had reached a high value and could perhaps not be expected to rise much more, the Executive Committee had decided to adhere to its original recommendation and propose a change to the Swiss Franc for the unit of currency for subscriptions. Although the Statutes give the Executive Committee the right to decide on this matter, the General Assembly was being asked for comments as not every country has easy access to all currencies. No adverse comments had been received from National Committees prior to the General Assembly.

At the request of S. C. ABrahams (USA), the Treasurer reported that the Swiss Franc had moved from SwFr 1.6 to the US dollar at the end of 1979 to a rate in August 1981 of SwFr 2.185 to the US dollar. F. W. B. EINSTEIN (Canada) asked in which currency the bulk of the Union's transactions takes place. The Treasurer replied that for the journals the main currencies were the Danish krone and the pound sterling and by asking the printers to quote in Danish kroner, some steps were being taken to offset the effects of variations in exchange rate between these two currencies. Expenditure on the General Fund could be any currency, except that the dues to ICSU and the capitation from ICSU were paid in US dollars. Grants to meetings and other grants could be expressed in whatever currency the Executive Committee wished and this could be Swiss Francs, which would insulate the Union against exchange rate changes. R. A. Young (USA) noted that the US delegation would abstain and would accept the decision made. An informal vote was then taken. There were no votes against the change, although there were a number of abstentions. The General Secretary pointed out that, although this was not a voting matter, he was glad to feel that the General Assembly supported the recommendation of the Executive Committee. 


\section{(42) Change in the unit of currency for the Union's accounts}

The Treasurer noted that as it had been agreed to change the currency of the unit subscription, it would also be sensible to change the currency of the accounts. He felt that accounts in Swiss Francs would give a better indication of the real fluctuations in the Union's cash flow and overall financial position. It might be necessary to add an additional note when submitting the accounts to ICSU, but that was not greatly significant. If the General Assembly agreed with the change, then the next accounts would be presented in Swiss Francs. This was agreed unanimously.

\section{(43) Determination of the general policy and the timetable} for the period to the Thirteenth General Assembly

The General Secretary noted that this was the time for the General Assembly to raise any points referring to Union policy, meetings, sponsorships etc., for the next triennium. A proposal had been received from the US National Committee for guidelines concerning satellite meetings at Congresses. The Executive Committee had proposed an amendment to these guidelines which would be considered after the general policy had been approved.

The President asked if there were any other points regarding the next triennium. R. DIAmOND noted that the Commission on Crystallographic Computing was intending to organize a further school on crystallographic computing and would be asking the Union for funds at some time during the next triennium. E. KALDIS also noted that the Commission on Crystal Growth and Characterization on Materials would be holding a school in Egypt, probably in March 1982. D. M. BLow (UK) noted that the US delegation had asked for a first circular to be produced eighteen months in advance of the next Congress. He noted that there had been problems in the UK because of the late arrival of the second circular for the present Congress. Until people are aware of how much the Congress is to cost they will not make a final decision on their attendance. This information is required in the UK for obtaining a grant to attend the Congress. Professor BLow therefore asked that the second circular giving estimated costs be available about twelve months before the Congress so that such an application for funds could be made. K. FISCHER (Federal Republic of Germany) said that the Organizing Committee would do its best; the zeroth circular for the Hamburg Congress had already been distributed at the present Congress. F. W. B. EINSTEIN (Canada) said that everyone would like to meet the USA and UK recommendations. However, to produce the second circular twelve months in advance means costing fifteen months in advance, an extremely difficult task under present economic conditions. He wished the organizers of the next Congress luck in trying to achieve this. The Canadian organizers of the present Congress had made every effort and he expected the German organizers to have some problems. R. A. Young (USA) said that the UK delegates had asked for estimatess, not that the estimates be correct.

A. J. C. WILSON noted that there was not the same uncertainty about the times as there was about costs. He asked that it be made clear in the first circular at what times delegates and other crystallographers needed to arrive at the Congress, for example whether the Opening Ceremony was to be held in the morning or the afternoon.
The President then asked the General Secretary to present the guidelines for satellite meetings, as amended by the Executive Committee. These were:

1. The establishment of a satellite meeting and its programme should be approved by the Organizing and Programme Committees of the host country.

2. Satellite meetings should be located within easy access of the Congress. Consideration should be given to possible difficulties that may arise from holding a satellite meeting in a country other than the one that is hosting the Congress.

W. EYSEL (Federal Republic of Germany) asked if the reason for the last sentence of guideline 2 was because people might have difficulty crossing borders for political reasons. Professor Young confirmed this. The guidelines were unanimously accepted by the Assembly.

\section{(44) Preliminary consideration of activities for the period 1984 to 1987}

The General Secretary noted that this item was required by statute to be on the General Assembly Agenda. The only activity he was aware of in the period concerned was the General Assembly and Congress in Australia in 1987.

\section{(45) Budget estimates and unit contributions for the period until the Thirteenth General Assembly}

The Treasurer pointed out that at the time when the budgets distributed with the Agenda, and printed as Annex I, Appendix I to these Minutes, were prepared the establishment of an in-house typesetting system was still viable; two budgets were therefore prepared. As the Executive Committee had decided not to proceed with the in-house typesetting facility, the second budget had to be considered. All the figures had been given in US dollars, but should be converted to Swiss Francs after the decision of the General Assembly earlier in the session. The Treasurer noted that the income and expenditure were nearly in balance; these estimates had been calculated on the basis of a unit contribution of US $\$ 360$ or the equivalent in Swiss Francs. At the time of preparation SwFr 730 was equivalent to US $\$ 360$. At the time of the Congress the rate had changed so that US $\$ 360$ was equivalent to SwFr 800 . An alternative proposal had been received from the UK National Committee, that the unit contribution should be fixed at $\$ 400$. The Treasurer was happy to receive this recommendation, which would be equivalent to a unit contribution of SwFr 890 at current exchange rates.

The Treasurer asked the General Assembly to discuss the size of the unit contribution and, as required in Statute $5.10(k)$, to fix the contribution for the period of the next General Assembly. F. W. B. EINSTEIN (Canada) proposed that the figure of SwFr 890 should be put to the General Assembly as the unit contribution for the years 1982 to 1984. The President, however, felt that there should be a little more discussion before the matter was put to a vote. D. $M$. BLow (UK) asked if the figure of US $\$ 90000$ given as the yield from investments and banking accounts was likely to be realistic and whether it would continue to be the same in Swiss Francs. The Treasurer replied that the figures were not given in current dollar values, but the investments were in sterling and would not yield the same figure at the current dollar rate. He noted that it was difficult to calculate the 
value in Swiss Francs, but M. M. Woolfson (UK) pointed out that the effect of exchange rates changing would be the same on both income and expenditure in the accounts. $H$. STEINFINK (USA) asked what the rate of return on investments was. The Treasurer replied that the present Swiss rate was about $7 \%$ and the UK rate $15 \%$. The US rate had been running at about $20 \%$, but the financial expertise necessary to take advantage of the upsurge in the American market at the appropriate time had not been available to the Union.

The President then proposed that SwFr 890 should be put to the vote as the unit contribution for the period to the next General Assembly. B. K. VaINSHTEIN (USSR) asked why the Executive Committee's proposal was not being put to the General Assembly. The President replied that it was normal procedure to put an amendment before the main motion. When the proposal was put to the vote there were 31 in favour, 21 against and 13 abstentions. The General Secretary referred to Statute 5.8 which stated that there should be a simple majority of the votes cast. He said that, by definition, abstentions were not votes cast and therefore of the votes cast, 52, 31 were in favour, which was a simple majority. The UK proposasl of a unit contribution of SwFr 890 (equivalent to US $\$ 400$ ) was therefore agreed.

\section{(46) Confirmation of the appointments of the Editors of the publications of the Union}

In accordance with Statute 7.1, the initial appointments and reappointments of the Editors of the publications of the Union were made by the Executive Committee and were subject to conformation by the General Assembly. The Assembly unanimously confirmed the following reappointments for the period of three years:

Editor of Acta Crystallographica: S. C. Abrahams (USA) Editor of Journal of Applied Crystallography:

M. Hart (UK)

The Assembly also unanimously confirmed the appointment of G. Ferguson (Canada) to succeed J. Trotter (Canada) as Editor of Structure Reports from the end of the present General Assembly.

The Executive Committee had not yet been able to find a replacement for Th. Hahn who wished to resign as Editor of International Tables after completing volume A of the new series.

The President thanked Professor Trotter and Professor Hahn for their periods of devoted service to the Union in editing their respective publications. This vote of thanks was approved with acclaim.

The President adjourned the meeting at 9.25 p.m.

Fourth Session, Tüesday 25 August 1981, 2.30 p.m.

(47) Good wishes and votes of thanks

E. N. MASLEN (Australia) proposed that the General Assembly send a telegram of greeting to the Executive Secretary, Dr J. N. King, with best wishes for his speedy recovery. This was greeted with acclaim. The President reported that the Executive Committee had already sent a telegram, but they would pass on the best wishes of the General Assembly to Dr King.

R. A. Young (USA) proposed a vote of thanks to the Organizing Committee of the present Congress, not only for the formal aspects of the Congress, but also for the opportunities they had arranged for personal interactions between scientists. This was also approved with acclaim.

\section{(48) Unit contribution for the period until the Thirteenth} General Assembly

S. HosHino (Japan) commented on the decision taken at the previous session on the unit contribution for the period until the Thirteenth General Assembly. He noted that the UK delegation's amendment had been approved by the General Assembly, but he felt that financial matters were the most important matters considered by the General Assembly and that any amendment should be given to all delegates before the session in which it is to be considered so that delegates have time to discuss the matter with their National Committees. In the present case the amendment was only communicated to delegates orally and not in writing. Furthermore, no revised budgets with the modified unit contribution were shown. Although the Statutes and ByLaws may allow for such a procedure, Professor Hoshino felt that it made matters very difficult for delegates, particularly as they had discussed the original Executive Committee proposals before the Congress and made representations to their governments. He added that, for delegates whose mother-tongue was not English, following business meetings such as the General Assembly was even more difficult and he asked that important items, particularly those with financial implications, should be notified to delegates in writing. The Japanese National Committee would consider proposing an amendment to the Statutes and By-Laws on this matter for consideration at the next General Assembly, but Professor Hoshino asked that his statement be included in the minutes of the present General Assembly.

A. A. Chernov (USSR) commented that Professor Vainshtein had proposed at the previous meeting that the Executive Committee proposal of $\$ 360$ be considered before the UK proposal of $\$ 400$. The General Secretary had replied that the By-Laws said that the amendment should be considered first. Professor Chernov commented that there appeared to be nothing in the By-Laws on this issue. He felt that, although this procedure may be self-evident in certain countries, the opposite procedure and order of voting was self-evident in other countries. Furthermore, the increase to $\$ 400$ represented a $33 \%$ increase and the voting did not represent a very convincing majority, particularly as seven of those present appeared not to have taken part in the voting at all. As the unit contribution is a very important matter, it is important not to have uncertainties on the decision regarding its magnitude. The USSR delegation therefore proposed that the question of unit contribution be reconsidered and a vote taken on the original Executive Committee proposal. The USSR delegation also proposed that rules of voting be introduced into the By-Laws in order to avoid future misunderstandings. A. AuthIER (France) said that the French delegation was in agreement with the Japanese and USSR delegations. J. GARAJ (Czechoslovakia) also expressed this view.

D. M. BLow (UK), at the President's request, made a statement on the matter. The British delegation was well aware of the problems which their proposals would produce for other delegations. However, as soon as the British National Committee had discussed the Agenda, Professor BLow had written to the President to inform him of their 
proposal. The Executive Committee therefore had had the opportunity to circulate this to other delegates. The proposal had been intended as a comment on the financial position of the Union and an indication of a route to its improvements; Professor BLow had not expected the proposal to be approved and was completely willing for the question to be reconsidered. The President commented that it was unfortunate that, because the third session of the General Assembly had been held on a Saturday and the Xerox machine had broken down, it had been virtually impossible to obtain Xerox copies in time for that session.

M. M. WoolfSon (UK) expressed sympathy with the viewpoint of the Soviet, Japanese and French delegations and felt that such matters should be subject to a control, so that delegates had the opportunity to discuss matters before they left from home. However, Professor Woolfson pointed out that logically it was necessary for voting to take place in the order in which it had, as the amendment to the motion had to be considered before the main motion itself.

W. ErSEL (Federal Republic of Germany) asked if there was a possibility of going back to reconsider the decision for, if this was not the case, then further discussion would be pointless. G. S. D. KING (Belgium) suggested that perhaps the British delegation should have withdrawn their proposal after discussion if they did not intend it to be carried. D. M. BLow (UK) pointed out that he said that it was not a question of intention but expectation.

The General Secretary said that he understood the delegates' reservations. The situation was quite new as this was the first time that there had been an amendment to the Executive Committee proposal for the unit contribution and therefore unfortunately the Executive Committee had not been completely prepared. The lack of a working Xerox machine had unfortunately made the situation worse. However, Professor RAsmussen confirmed that all the procedures followed had been correct; no objections had been received from any delegate at the General Assembly, which has the final decision on any procedural matter. Professor RASMUSSEN regretted any misunderstanding with Professor Vainshtein, but that did not alter his opinion that the correct procedure had been followed. He explained in more detail the normal procedures for handling amendments to motions, and noted that it was the Chairman's responsibility to decide whether an amendment was an amendment or a completely new motion. In the present case it had been considered reasonable to consider a percentage increase of $10 \%$ on the figure proposed as an amendment and not as an entirely new proposal. He, like Professor Blow, had not expected the amendment to be carried. He understood, however, the difficulties of some non-English-speaking delegates in following the arguments put forward and suggested that it would be possible for the matter to be reconsidered if there was unanimous agreement of the General Assembly to do so and if the UK proposal still stood. However, the procedure would be the same, that a vote would be taken on the amendment before that on the main motion.

J. GARAJ (Czechoslovakia) said that he was unable to be present at the last session of the General Assembly, but he would like one of the UK delegates to explain the proposed increase in unit contribution, particularly in view of the comments made at the previous General Assembly in Warsaw by one of the UK delegates in opposing a rise in the unit contribution. M. M. Woolfson (UK) explained that the rise had been proposed, after long discussion in the UK National Committee, in order to take account of inflation over the three-year-period and the UK delegation felt that a $33 \%$ rise over three years was justified in the circumstances.

In answer to a question from $H$. WondratscheK (Federal Republic of Germany), the President confirmed that the unit contribution had in fact been fixed in Swiss Francs and not in US dollars, at a figure of SwFr 890.

A. Authier (France) asked if the British delegation would be willing to accept a new vote as they had proposed the original amendment. F. W. B. EINSTEIN (Canada) proposed that a five-minute recess be taken before this was considered. S. Martinez-Carreras (Spain) said that, although she had voted against the British proposal, she did not feel that the vote should be taken again as this could lead to a meeting which would never finish. D. RABINOviCH (Israel) said that, although the majority was not large in favour of the British proposal, it was large enough.

At this point F. W. B. EINSTEIN (Canada), seconded by E. N. MASLEN (Australia) moved that the General Assembly move on to the next Agenda item. A. A. Chernov (USSR) said that before the General Assembly moved on to the next item, he would like to know whether the General Assembly were in favour of reconsidering this matter or not. D. M. BLow (UK) said that the UK delegates would not withdraw their proposal, but were willing to defer to the President as to whether the issue should be reopened. K. V. J. KURKISuonio (Finland) said that he was in no doubt that the decision taken was legal. However, he was also in no doubt that the General Assembly was the highest authority in the Union and had the power to change its mind. Furthermore, the flow of events at the previous session had been too rapid and had created confusion in delegates' minds. Professor KURKI-SuONIO therefore felt that there was a danger of spoiling the atmosphere and undermining the confidence of delegates and, on that account, he proposed that the matter should be reconsidered. F. W. B. EInstein (Canada) again proposed that there be a five-minute recess and this was generally agreed. A five-minute recess was therefore taken.

After the recess the President reopened the session and said that the proposal before the General Assembly was that in order to avoid the confidence of the General Assembly being undermined, the vote on the British proposal should be taken again. He asked the General Secretary to clarify the position regarding the statutes. The General Secretary repeated that it had not been challenged that the decision was constitutional and he emphasized that the voting was not at variance with the Statutes and By-Laws. He suggested that, as the Statutes did not deal with reopening business, the only way for this to be decided would be by unanimous agreement of the General Assembly. There was a short discussion of procedure and F. W. B. EINSTEIN (Canada) urged delegates to vote unanimously to reopen this matter so as to avoid any future ill-feeling on the matter. No-one objected to the proposal that only a unanimous decision would make it possible to reopen an agenda point already voted upon. When a vote was taken there were twelve votes against reopening the matter and therefore the previous decision was taken as binding.

The President summed up by saying that he regretted the ill-feeling caused on this matter and in future all items concerning finance would be distributed in time for them to 
be given the necessary consideration by delegates. On the question of changing the Statues, this was not an easy matter, but the Executive Committee would take into account the opinions expressed by delegates before any proposals were made.

\section{(49) Donations to the Union}

The Treasurer reported with pleasure that the Japanese crystallographic community had collected a large sum, seven million Yen, about $\$ 35000$, as a donation towards the Union publications, with particular reference to the setting up of an in-house typesetting facility. The Executive Committee had accepted the donation with gratitude and also wished to authorize all National Committees, if they so wished, to solicit donations in their own countries towards the work of the Union, particularly its journals, in order to overcome the existing financial crisis. According to the Statutes and By-Laws Executive Committee approval is needed if such solicitation of donations is to be undertaken and such authorization was now given. This was received with acclaim.

S. Hoshino (Japan) explained that several months previously some members of the Japanese National Committee and of the Crystallographic Society of Japan had heard that the Union was facing financial problems, particularly with the proposed installation of an in-house typesetting system. They had therefore decided to make a collection amongst crystallographers in Japan and had raised the seven million Yen referred to by Professor Rasmussen. Professor Hoshino had written to Professor Rasmussen and asked the Executive Committee to accept this donation. When the Japanese crystallographers had been informed that for financial reasons it had been necessary not to proceed with the installation of the in-house system, they had naturally been disappointed, but they felt that if the donation could be used to help publications of the Union in future, possibly even in the setting up of a typesetting unit, then they would be happy. Professor Hoshino's comments were greeted with applause.

The General Secretary reported that Professor Kato would like to correct one point in the Appendix relating to in-house typesetting (Annex I, Appendix C). The initiative for collecting the donations in Japan had come from Professor Hoshino and not from Professor Kato.

\section{(50) A charge for publishing?}

The President said that the notes which had been circulated (printed as Annex I, Appendix $J$ to these Minutes) were not intended as a proposal, but purely as a means to elicit the views of delegates. R. P. OzERov (USSR) said that certain countries had non-convertible currencies and therefore, although exceptions could be made, this would be a form of discrimination and therefore the USSR delegation felt obliged to oppose a charge for publishing. The USSR delegation understood the financial situation of the Union journals, but did not feel that a publication charge was the solution. They felt that other possible solutions should be investigated further and the USSR would play its part. The General Secretary replied that the Executive Committee was aware that publication charges were felt to be discriminatory in certain countries and therefore they had been avoided in the past. It had been pointed out, however, that publication charges paid by scientists in those countries whose currencies were convertible would have the effect of reducing the price of the journals and therefore making them more easily available to scientists in countries where foreign currencies were not easily available or where funds were restricted. It was from considerations of making the journals more easily available to scientists in such countries that the Executive Committee had decided to bring the question of nonmandatory page charges before the General Assembly for its opinion. While the Executive Committee was very aware of those feelings that this could be regarded as discrimination, they also felt that the view that 'If you pay a page charge, I can afford the journal' should also be considered. J. GARAJ (Czechoslovakia) said that he was afraid that if there were publication charges, then scientists in some countries would no longer publish in Acta but in their own national journals.

R. A. Young (USA) said that he was very aware of the financial problems of the Union journals and that if some action were not taken, then there could be no journals at all. He accepted Professor Ozerov's comment that another way would be preferable, but he found it difficult to know if there was another way. If page charges were non-mandatory and therefore no-one from a country with a non-convertible currency would be prevented from publishing in the journal, then he could see no objection to the introduction of such charges. E. N. MASLEN (Australia) said that he found the proposal unpalatable, but that if the choice was between an unpalatable solution and closing down the journals, then he would accept the unpalatable solution. D. RABINOVICH (Israel) asked if the proposal would save the journals; the question was not whether the proposal was palatable or not palatable, but whether it would be effective. The Treasurer replied that the larger the income for the journal, then the smaller would be the increases in subscription prices. He added that if crystallographers wanted journals it was up to them to support them. If they did not read them, publish in them, or buy them, then there would be no journals. If a crystallographer wished to support the journal he could in the first place buy it, and then if he wished to support his less fortunate colleague, he could pay a publication charge to enable his colleague also to buy it. In other words, would the crystallographers in affluent countries be willing to pay publication charges to help their colleagues in less affluent countries? D. M. BLow (UK) said that he agreed with those who were reluctant to accept publication charges and he felt that they would be divisive between countries. He asked if the Executive Committee had considered a campaign to encourage more people to take out personal subscriptions and to encourage research groups to take out subscriptions additional to those in their central libraries. The General Secretary said that the Executive Committee had tried publication drives, but without much success in the past. He suggested that the matter be referred to the Finance Committee. A. AuthIER (France) said that in view of the changes being proposed for Acta by the Commission on Journals, in order to give journals which are more attractive to crystallographers, then these changes should be advertised widely in order to encourage greater sales of the journal. S. C. ABrahams (USA) said that as far as he understood the Executive Committee position, there would be no connection between payment of publication charges and priority of publication. The editors concerned with the publication of a particular paper would be unaware whether a publication charge was being paid or not and only those 
who could pay would do so. In this way no-one should feel discriminated against.

The President asked if there were any suggestions as to how an advertising campaign could be carried out. D. M. BLow (UK) said that until he saw the financial statements with the General Assembly papers, he was unaware of the deep financial problems concerned with the journals. He felt that most crystallographers were unaware of these problems and the first step was to inform people that they existed. Secondly there were well tried marketing techniques which could be used and, if people were aware that by ordering the journals they were not only helping the Union but also helping the journals to survive, then a drive might be successful. M. M. WOOLFSON (UK) pointed out that, at least in the UK, journal subscriptions were liable for tax exemption and this was one way of transferring money from governments to the Union. E. KALDIS (Switzerland) said that the only way of making the journals attractive to more scientists was to cover a wider field. He therefore suggested that reviews of new fields on the periphery of crystallography should be invited. which may be attractive to a wider range of authors and readers.

The President thanked the delegates for their comments and said that the new Executive and Finance Committees would look at the question. The President then asked if there was any other business.

\section{(51) European Crystallographic Committee}

J. KARLE (USA) reported that the European Crystallographic committee had held new elections. The new President was Professor B. Kamenar, the Vice-President Professor G. S. D. King and the Secretary continued to be Professor P. T. Beurskens. Dr KARLE also noted that, as well as the 1982 meeting in Israel, the 1983 European Crystallographic Meeting would be in Liège, Belgium and the 1985 European Crystallographic Meeting in Torino, Italy.

\section{(52) Votes of thanks}

A. AUTHIER proposed a vote of thanks to the retiring members of the Executive Committee, particularly Professors Kato and Rasmussen, for their work over the past years. This was approved with acclaim.

A. A. Chernov (USSR) expressed the General Assembly's gratitude to their Canadian colleagues of Carleton University. This was also supported with acclaim.

The President closed the General Assembly at 16.12 p.m.

\section{Closing Ceremony, Tuesday 25 August, 1.00 p.m.}

The Closing Ceremony was held in Theatre A of Southam Hall before the last session of the General Assembly. Many members of the Congress attended this ceremony. F. W. B. EINSTEIN, Chairman of the Canadian National Committee. took the chair.

\section{Votes of thanks \\ The following votes of thanks were approved with acclaim:}

(a) S. Abrahamsson (Sweden) spoke on behalf of the participants at the Congress. He spoke of the Congress playing an important role in bringing together experts and he felt that this had been done most successfully in the excellent facilities provided. He thanked the National Research Council of Canada for their kind invitation to hold the Congress and General Assembly in Ottawa. He thanked the Organizing Committee, L. D. Calvert (Chairman), F. R. Ahmed, A. Beauchamp, G. I. Birnbaum, F. R. Brisse, S. Brisse, M. Cygler, F. W. B. Einstein, E. J. Gabe, P. E. Grattan-Bellew, C. P. Huber, F. Lee, Y. Le Page, K. S. Miliken, C. M. Mitchell. M. E. Pippy, M. L. Post. M. Przybylska, A. C. Roberts, H. M. Sheppard, J. T. Szymanski and $K$. Charbonneau (Executive Secretary).

(b) A. J. C. WILson, the retiring Vice-President, spoke of the gratitude of the crystallographic community, and of the Executive Committee in particular, to the Programme Committee, F. R. Ahmed (Chairman), U. Bonse, H. B. Bürgi, K. Łukaszewicz. E. N. Maslen, D. C. Phillips, S. A. Semiletov, R. A. Young and M. E. Pippy (Secretary). Professor WILSON said that the scientific content of the Congress had been a magnificent success. Although it was frustrating not always to be able to attend all the papers one wished. crystallographers had only themselves to blame for producing so many good papers. Although he did not wish to comment on individual papers and posters, it was a pleasure to see the renaissance of powder methods, which had been very important in the early days of crystallography but had until recently taken on a Cinderella role.

(c) L. D. CAlvert, Chairman of the Organizing Committee, thanked the speakers for their kind expressions. He thanked all those at the National Research Council of Canada who had helped in the organization of the Congress, especially the President and the staff of the conference services section. He thanked the Atomic Energy of Canada Limited, Energy, Mines and Resources Canada and the Government of Ontario for their financial support. He thanked the members of the Programme Committee and all members of the Organizing Committee and their friends and relatives who had put in such a great effort to make the Conference successful. Finally he thanked the Conference staff at Carleton University.

(d) F. R. Ahmed, Chairman of the Programme Committee, said that the Committee had been working for over two years and he had been in close touch with National Committees, Commissions and many other colleagues during that time. He was grateful to all who had contributed to the programme in whatever way. In particular he thanked his personal assistant, Mrs M. E. Pippy, for all her work in this regard. He said that if participants felt that they had made a contribution to someone else's work, if they had found other ideas exciting, or if the Congress had given old friends and new friends the opportunity to meet, then it had been worth while. He thanked all those who had provided grants, those who had given lectures, the IUCr and all participants for making this possible.

(e) The retiring President of the Union, N. Kato, expressed his gratitude to the National Research Council of Canada and to the Organizing Committee. He also thanked the retiring members of the Executive Committee, Professor A. J. C. Wilson, Professor S. E Rasmussen, Dr F. R. Ahmed and Professor E. F. Bertaut. He particularly mentioned Professor Rasmussen, whose work was well known to all crystallographers. Professor Kato then introduced the newly elected President, Dr J. Karle, the newly elected General Secretary and Treasurer, Professor K. V. J. Kurki-Suonio, and the other newly elected members of the Executive 
Committee. Professor Kato said that it had been a notable Congress. The Portugese Physical Society had been received into membership of the Union and a new Commission on Biological Macromolecular Crystallography had been created. Some of the difficult problems facing the Union had been solved, and he was confident that the situation would continue to improve under the new President.

(f) Dr KARLE thanked Professor Kato for the very fine work he had done as President. He said that he had been very impressed with both the quality and the quantity of the information presented at the Congress and had recognized a quantum jump in information in certain fields. Seeing the results of work, not all done under ideal conditions, had made him proud to be a part of a community of competent and dedicated scientists. Dr Karle said that he was honoured to represent this crystallographic commmunity as its President and he would make every effort to ensure that the Union and the science of crystallography continued to move ahead. Finally he said that he would look forward to meeting all of those present in Ottawa at Hamburg in 1984.

Professor KATo then declared the Twelfth General Assembly and Congress officially closed at 1.30 p.m. 


\section{ANNEX I}

\section{Appendices to the Agenda of the Twelfth General Assembly}

\section{Appendix A: Report of the Executive Committee}

\section{Meetings}

Since the Eleventh General Assembly and International Congress of Crystallography in Warsaw, many meetings have been held, or will be held prior to or immediately after the Twelfth Congress, which have received Union sponsorship. These meetings are: Summer School on Diffraction Studies of Non-Crystalline Substances, Pécs, Hungary, 14-18 August 1978; Conference on Diffraction Line Profile Analysis, Cracow, Poland, 14-15 August 1978; Sixth International Symposium on Boron and Borides, Druzhba, Bulgaria, 9-12 October 1978; Inter-Congress Meeting on Modulated Structurs, Kailua-Kono, Hawaii, USA, 22-25 March 1979; Inter-Congress Symposium on Accuracy in Powder Diffraction, Washington DC, USA, 11-15 June 1979; Fifth European Crystallographic Meeting, Copenhagen, Denmark, 13-17 August 1979; Sagamore VI Conference on Charge, Spin and Momentum Densities, Mont Tremblant, Quebec, Canada, 19-25 August 1979; Winter School on Crystallographic Computing, Bangalore, India, 4-14 January 1980; Spring School on New Crystallographic Perspectives in Materials Science, Erice, Italy, 8-21 April 1980; Sixth European Crystallographic Meeting, Barcelona, Spain, 28 July-1 August 1980; Sixth International Conference on Crystal Growth, Moscow, USSR, 10-16 September 1980; Fourth International Specialists' School on Crystal Growth, Susdal, USSR, 17-25 September 1980; Applications of the Mössbauer Effect, Srinivar, India, 13-17 July 1981; International Summer School on Crystallographic Computing, Ottawa, Canada, 7-15 August 1981; Neutron Diffraction Conference, Argonne, USA, 12-13 August 1981; Symposium on Crystallography in the Health Sciences; Crystalline Deposits in Human Tissues, Toronto, Canada, 13-14 August 1981; Symposium on Biologically Active Molecules, Buffalo, USA, 26-28 August 1981.

The Executive Committee met in Warsaw in August 1978 before and during the period of the Eleventh General Assembly, in Copenhagen, Denmark, 10-13 August 1979 and in Barcelona, Spain, 24-28 July 1980.

At the Executive Committee meetings in 1979 the most important items of business were (1) sponsorship of meetings; (2) arrangements for the Twelfth General Assembly and Congress, including the membership of the Congress Programme Committee; (3) approval of the audited accounts for 1978; (4) possible change in the currency of the subscriptions paid by Adhering Bodies; (5) subscription rates and other matters concerning the Union's journals, including the establishment of in-house composition facilities; (6) appointment of a new publisher for Structure Reports and other publications of the Union; (7) the new volume on direct space of International Tables for Crystallography; (8) preparation of a book Fifty Years of Electron Diffraction; (9) preparation of a Sixth Edition of the World Directory of Crystallographers.
At the Executive Committee meeting in 1980 the most important items of business were (1) the arrangement for the Twelfth General Assembly and Congress with the Programme Committee; (2) establishment of an in-house computerized phototypesetting system, consideration of subscription rates and other matters concerning the Union's journals; (3) other publications of the Union; (4) sponsorship of meetings; (5) approval of the audited accounts for $1979 ;(6)$ the General Fund estimates and the level of the unit contribution for 1982-1984; (7) suggestions from National Committees for membership of the Executive Committee and the Commissions; (8) establishment of a Commission on Biological Macromolecular Crystallography; (9) the proposed location of the Fourteenth General Assembly and Congress.

More detailed reports of the activities of the Union are contained in the annual reports of the Executive Committee, which are published in Section A of Acta Crystallographica.

\section{Publications}

The Union's publication programme continues to provide a most important service to the crystallographic community, and the Executive Committee has been particularly concerned with the rising costs of publication. In 1978 a working party was set up to consider the feasibility of the Union establishing its own computerized typesetting system, with the primary objective of minimizing the increasing cost of typesetting the journals. The membership was Professor S. E. Rasmussen (Chairman), Dr S. C. Abrahams, Dr J. N. King, Dr D. W. Penfold and Mr E. Skov Jensen.

The working party reported to the Executive Committee in 1979 , and recommended that it should continue its work to establish a firm basis on which the Executive Committee could make a decision on installing a suitable system. A schedule was proposed for further assessment of such systems, for installation of a system in 1981 and for setting the journals to be published from January 1982. The Executive Committee endorsed the report and authorized the appointment of a firm of computer consultants to advise the working party. $\mathrm{Mr}$ J. H. Thomas of Logica Ltd was appointed to this task.

A functional requirements specification was prepared and many systems were assessed. Dr Penfold, Mr Skov Jensen and $\mathrm{Mr}$ Thomas visited four installations. Dr Penfold and $\mathrm{Mr}$ Thomas compiled a detailed report which was presented to the Executive Committee in July 1980. In the report three short-listed systems were evaluated, staffing and operational requirements were assessed and a financial analysis and implementation plan were presented. Dr Penfold and $\mathrm{Mr}$ Skov Jensen attended the Executive Committee meeting in Barcelona in July 1980 to discuss the report. The Executive Committee authorized the President and the Treasurer of the Union to make the final decision on the installation of a system in Chester. In September Dr Penfold visited several installations in North America and presented his final recommendations, which lead to a provisional order being placed for a Bobst Mopas system and typesetter. However, 
exchange rate fluctuations and exceptionally large expenditure in 1980 lead to a heavy deficit being incurred for the Union's publications in that year, with the result that severe cash-flow problems are expected in 1981 and 1982 if the Union sets up the proposed typesetting system. Several ways of obtaining temporary financial assistance are currently being explored, and the decision on whether to install the system has had to be deferred until these financial difficulties are resolved.

In 1978 the number of pages in Section A of Acta Crystallographica was 1048 and in Section B was 3848 , making a total of 4896 pages, excluding the 80 -page joint index and the supplement containing 431 pages of abstracts communicated to the Eleventh Congress. In 1979 and 1980 the total number of pages were 4220 (Section A, 1090; Section B, 3130) and 4308 (Section A, 1096; Section B, 3212) respectively.

In 1978 the Journal of Applied Crystallography consisted of 733 pages, excluding indexes. In 1979 the number was 642 pages and in 1980638 pages.

For Structure Reports, Volume 41B for 1975 and Volume $42 \mathrm{~A}$ for 1976 were published in 1978, Volumes $42 \mathrm{~B}$ and $43 \mathrm{~A}$ in 1979 and Volumes 43B and 44A in 1980.

Volumes 9, 10 and 11 of Molecular Structures and Dimensions were also published.

\section{Commissions of the Union}

Each Commission Chairman is required to provide a written triennial report to the General Assembly. These reports are given as Appendix D.

\section{Scientific and Regional Associates}

The reports of the representatives on these bodies are given as Appendix E.

\section{Union Representatives on Other Bodies}

The reports of the representatives of the Union on other bodies are given as Appendix F.

\section{International Council of Scientific Unions (ICSU)}

Professor A. Magnéli represented the Union at the 1978 and 1979 meetings of the ICSU General Committee and the 1978 ICSU General Assembly, whilst Professor N. Kato represented the Union at the 1980 meeting of the General Committee and General Assembly. Dr J. N. King also attended the General Assemblies. Reports on the scientific activities of the Unions and other scientific organizations were prepared at all these meetings.

In 1978 the General Assembly (1) accepted the Royal Irish Academy as a National Member; (2) increased the contributions from National Members; (3) endorsed the proposal of Unesco for an International Year of Science; (4) invited the Unions to contribute to SCOPE's programme in relation to the biogeochemical cycling of carbon, nitrogen, sulphur and other appropriate elements; (5) decided to review the role and status of Scientific Associates; (6) resolved to establish a study group on the scientific aspects of nuclear waste disposal; (7) initiated steps to consider ways of adapting the organizational structure of ICSU to meet the changing patterns and needs of science; (8) changed the Special Committee on Solar-Terrestrial Physics into a Scientific Committee; (9) resolved to create an interdisciplinary Inter-Union Commission on the Application of
Science to Agriculture, Forestry and Aquaculture; (10) supported the preparation of a document on Science, Technology and Development: Views from Scientists in the Developing World; (11) invited renewed efforts to welcome scientists from the People's Republic of China into ICSU; (12) invited the Unions and the National Members to take into account the needs of scientists in developing countries concerning scientific information. The proposal to introduce a $\$ 5$ tax on participants at Union-sponsored meetings was not accepted.

Decisions and recommendations by the 1979 General Committee covered matters such as undisturbed radiofrequencies for radioastronomy and space research, cooperation with the United Nations Development Programme (UNDP) in the period immediately following the UN Conference on Science and Technology for Development, cooperation with the United Nations Environmental Programme (UNEP) concerning an assessment of the extent of increase of carbon dioxide in the atmosphere and of the sensitivity of climate to such an increase, establishment of a steering committee with ICSU representation to carry out a feasibility study of an International Biosciences Centre, and support of an initiative by the International Union of Biological Sciences concerning action to deal with population problems.

In 1980 the General Assembly (1) accepted the Royal Scientific Society of Jordan and the Kenya Academy for the Advancement of Arts and Sciences as National Members; (2) supported an assessment of the problems of nuclear waste disposal; (3) invited National Agencies to consider the continued modernization of data-handling facilities in the world Data Centres; (4) endorsed the establishment of an Inter-Union Commission on the Lithosphere; (5) received the report of the Inter-Union Commission on the Application of Science to Agriculture, Forestry and Aquaculture, and supported further work in this field; (6) asked the Executive Board to consider ways of increasing the involvement of the international scientific community in the problems of the developing countries; (7) recommended the establishment of one or more international centres for tropical forestry research in Asia, Africa and Latin America; (8) endorsed the programme of the International Biosciences Network in fostering biological training and research in developing countries; (9) asked the ICSU officers to discuss with Unesco support for the oceanographic aspects of the World Climate Programme. The application from the People's Republic of China was withdrawn at the last minute. Proposals to change the representation and voting power of the Unions in ICSU, by forming 'super unions' or by grouping the Unions into three clusters to represent the physical, biological and earth/space sciences, were not acceptable to most Unions. The Executive Board will continue its attempts to find a solution which is acceptable to the General Assembly. A new system of allocating the Unesco subvention to the Unions will be introduced from 1982. The IUCr will receive a slightly smaller allocation than under the present system.

The Union has submitted to ICSU a proposal for inclusion in the Unesco Medium Plan for 1984-89, for the establishment of an International Institute for Crystallography in a developing country.

The Union continues to take part in the activities of several ICSU bodies. The triennial reports of the Union's 
representatives on these and other bodies are given as Appendices $\mathrm{E}$ and $\mathrm{F}$.

\section{Union Staff}

The present staff in Chester is: Dr J. N. King (Executive Secretary), Mrs A. Cawley (Secretary), Dr D. W. Penfold (Technical Editor), Dr J. E. Derry (Assistant Technical Editor), Mr M. H. Dacombe, Miss S. E. Lowe and Miss A. Sharpe (Editorial Assistants), Mrs J. I. Heywood and Mrs M. P. Thompson (Secretaries).

\section{Acknowledgements}

On behalf of the Union, the Executive Committee wishes to express its deep gratitude to the National Research Council of Canada for the invitation to hold the Twelfth General Assembly and International Congress of Crystallography in Ottawa. It particularly wishes to thank the Chairman of the Programme Committee, Dr F. R. Ahmed, and the Chairman of the Organizing Committee, Dr L. D. Calvert.

The continuing support shown by Unesco in the form of its annual subvention received by the Union through ICSU, and the support of ICSU itself, is gratefully acknowledged.

Finally the Executive Committee wishes to thank all those crystallographers who have assisted in the work of the Union in so many ways. This cooperation between crystallographers of different nationalities constitutes a most valuable aspect of the Union's activities.

May 1981.

\section{Appendix B: Financial Report}

The accounts of the Union for the calendar years 1978 and 1979 have already been published (Acta Cryst. (1978). A35, 1068-1083 and (1979). A36, 1072-1088). The accounts for 1980 have been audited and will be published in Acta Crystallographica, Section A, later in 1981 [Acta Cryst. (1981). A37, 922-941].

The accounts for the three years 1978,1979 and 1980 are summarized in Tables $1-10$, in which all the amounts are expressed in US dollars. Negative quantities are indicated by parentheses. The balance in each Fund Account at 31 December 1980 is given in Table 12. As a consequence of fluctuations in rates of exchange, a profit or a loss arose each year in terms of US dollars. This gain or loss was divided amongst the Fund Accounts with credit balances, in direct proportion to the balances on these accounts at the end of the year in question. The fluctuation in exchange rates gave rise to gains of $\$ 62718$ in 1978 and $\$ 25808$ in 1979 , and a loss of $\$ 52769$ in 1980 , leading to an overall gain of $\$ 35757$ on fluctuations in exchange rates during the triennium. The exchange rates in operation at 1 January 1978 were US $\$ 1=$ Netherlands guilders $2 \cdot 40=$ Danish kroner $6 \cdot 10=£ 0 \cdot 55=$ Swiss Francs $2 \cdot 17=$ German Marks 2.20. The exchange rates at 31 December 1980 were US $\$ 1=$ Netherlands guilders $2.08=$ Danish kroner $5.90=£ 0.424=$ Swiss Francs $1.71=$ German Marks 1.92.

When the Acta Crystallographica accounts (Table 1) are examined, it should be remembered that the full rate annual combined subscription (for both Sections) was Dkr 1960 in 1978, Dkr 2060 in 1979 and $\mathrm{Dkr} 2265$ in 1980. The numbers of pages published in each Section of the journal were as follows:

$\begin{array}{llll} & 1978 & 1979 & 1980 \\ \text { Section A } & 1048 & 1090 & 1096 \\ \text { Section B } & 3848 & 3130 & 3212 \\ \text { Total } & 4896 & 4220 & 4308\end{array}$

Section A also included 431 pages of Congress Abstracts in 1978.

The numbers of paid subscriptions to one or both Sections of the journal were as follows:

$\begin{array}{lrrr} & 1978 & 1979 & 1980 \\ \text { Sections A and B } & 1503 & 1453 & 1418 \\ \text { Section A only } & 248 & 253 & 250 \\ \text { Section B only } & 108 & 131 & 137\end{array}$

Included in these numbers were the following numbers of personal subscriptions at reduced prices:

$\begin{array}{lrrr} & 1978 & 1979 & 1980 \\ \text { Sections A and B } & 168 & 152 & 150 \\ \text { Section A only } & 54 & 59 & 61 \\ \text { Section B only } & 20 & 23 & 19\end{array}$

During 1980 the value of the Danish kroner dropped dramatically with respect to the dollar and sterling. This lead to a large increase in the publishing, editing and administration costs, since all these costs were incurred in sterling. In addition sterling prices for printing were increased by $20 \%$, and the prices for postage increased by an even higher percentage. In addition, costs of $\$ 22377$ were incurred in assessing the feasibility of installing the Union's own computerized typesetting system. Although the subscription rates in Danish kroner were increased by $10 \%$, the income when expressed in dollars was lower than for 1979. These factors resulted in a very large deficit being sustained for Acta Crystallographica in 1980. The account is particularly susceptible to fluctuations in the Danish kroner/ sterling exchange rates since nearly all the publishing and editing costs are incurred in sterling, whilst the income from sales is received in Danish kroner.

The Journal of Applied Crystallography accounts are given in Table 2. The full subscription rates were $\mathrm{Dkr} 480$, Dkr 500 and Dkr 550 for 1978, 1979 and 1980 respectively. The number of paid subscriptions remained almost unchanged, at 1178 in 1978,1180 in 1979 and 1168 in 1980 . In 1978720 pages were published, including 363 pages of papers and abstracts presented at the Fourth International Conference on Small-Angle Scattering at Gatlinburg in 1977. A contribution of $\$ 10000$ was received from the Conference organizers towards the cost of publishing these papers. In 1979 and 1980 the numbers of papers published were 720 and 638. A small deficit was incurred in 1979 and a larger deficit in 1980. The changes in exchange rates referred to earlier, and lower sales of back numbers, meant that the net income was less than that for 1979 when expressed in dollars, although the subscription rate was increased by $10 \%$. The printing and distribution costs were incurred in Danish kroner and therefore only increased slightly with respect to those for 1979 when expressed in dollars. However, the editorial and administration expenses, which were incurred in sterling, increased by a higher percentage. 
The Structure Reports accounts are shown in Table 3. Volumes $41 \mathrm{~B}$ and $42 \mathrm{~A}$ were published in 1978 , Volumes 42B and $43 \mathrm{~A}$ in 1979 and Volumes $43 \mathrm{~B}$ and $44 \mathrm{~A}$ in 1980. A substantial profit was achieved in 1979 but in 1980 there was a deficit.
A new publisher, D. Reidel Publishing Company, was appointed to deal with Structure Reports, Molecular Structures and Dimensions and the other publications of the Union, except International Tables, as from 1 January 1980. Although Reidel receives a higher commission on sales, it is
Income

Subscriptions

Sale of back numbers and single copies

Airfreight charges to subscribers

Royalties, copyright fees

Less Publisher's commission

Yield from advertisers

\section{Expenditure}

Printing and binding

Distribution and postage

Airfreight costs

Indexes

Congress Supplement

Assessment of computerized typesetting facility

Editorial expenses

Administration expenses

Difference between income and expenditure

Gain on fluctuations in rates of exchange

Accumulated balance at the end of the year

Table 1. Acta Crystallographica

\begin{tabular}{|c|c|c|c|c|c|}
\hline \multicolumn{2}{|c|}{1978} & \multicolumn{2}{|c|}{1979} & \multicolumn{2}{|c|}{1980} \\
\hline 519,053 & & 538,084 & & 524,977 & \\
\hline 26,998 & & 14,391 & & 17,921 & \\
\hline 8,887 & & 8,654 & & 7,646 & \\
\hline 27 & & 38 & & 122 & \\
\hline 554,965 & & 561,167 & & 550,666 & \\
\hline 54,605 & 500,360 & 55,207 & 505,960 & 54,113 & 496,553 \\
\hline & - & & 1,219 & & 1,103 \\
\hline & 500,360 & & 507,179 & & 497,656 \\
\hline 273,593 & & 299,983 & & 397,172 & \\
\hline 32,451 & & 33,228 & & 48,618 & \\
\hline 11,270 & & 11,742 & & 13,537 & \\
\hline 6,396 & & 8,353 & & 10,201 & \\
\hline 5,605 & & - & & - & \\
\hline- & & - & & 22,377 & \\
\hline 85,037 & & 137,547 & & 157,009 & \\
\hline 10,230 & 424,582 & 14,400 & 505,253 & 17,200 & 666,114 \\
\hline & $+\$ 75,778$ & & $+\$ 1,926$ & & $-\$ 168,458$ \\
\hline & 30,449 & & 11,699 & & $(17,980)$ \\
\hline & $\$ 386,395$ & & $\$ 400,020$ & & $\$ 213,582$ \\
\hline
\end{tabular}

Table 2. Journal of Applied Crystallography

Income

Subscriptions

Sale of back numbers and single copies

Airfreight charges to subscribers

Royalties

Less Publisher's commission

Yield from advertisements

\section{Expenditure}

Printing and binding

Distribution and postage

Airfreight costs

Congress Supplement

Assessment of computerized typesetting facility

Editorial expenses

Administration expenses

Difference between income and expenditure

Gain on fluctuations in rates of exchange

Accumulated balance at the end of the year
1978

1979
1980

$$
\begin{array}{r}
98,035 \\
4,182 \\
2,030 \\
9 \\
\hline 104,256
\end{array}
$$

12,753

91,503

$\frac{1,047}{92,550}$

61,153

3,035

2,614

1,869

14,566

3,410

$\begin{array}{r}86,647 \\ +\$ 5,903 \\ \hline 5,568 \\ \hline \$ 70,544\end{array}$
96,953

5,371

2,044

104,377

12,790

91,587

2,126

93,713

64,307

4,479

2,754

-

20,369

4,800

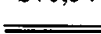

95,482

2,326

1,792

51

99,651

12,226

87,425

505

87,930

65,976

4,479

3,175

3,344

3,344
23,054

$5,750 \quad 105,778$

\begin{tabular}{l}
96,709 \\
\hline
\end{tabular}

$-\$ 17,848$

$(4,017)$

$\$ 47,718$ 
handling these publications in a much more efficient manner. However, a change in the invoicing procedure and a delay in the receipt of many orders from one agency resulted in a reduction in the sales income for 1980. Editorial expenses were exceptionally high in 1980 because payment was made for two B volumes as well as for one A volume during the year.

The International Tables for X-ray Crystallographv accounts are shown in Table 4. A sizeable donation was received in 1978. Income exceeded expenditure for 1978 , 1979 and 1980, even though in 19801000 copies of Volume IV were bound and Volume I went out of print. Editorial work on the new volume on Direct Space continued during 1979 and 1980.

Table 5 summarizes the accounts for Fifty Years of $X$-ray Diffraction, more copies being sold in 1980 as a result of a publicity campaign by the new publisher. Table 6 shows the accounts for Symmetry Aspects of M. C. Escher's Periodic Drawings, which continues to sell well. Royalties were received from commercial publishers for the North American edition published in 1976 and a Japanese edition published in 1980.

The Early Papers on Diffraction of $X$-rays by Crystals accounts are shown in Table 7 . No expenses were incurred

Table 3. Structure Reports

Income

Sale of copies

Expenditure

Printing and binding new volumes

Typing of manuscripts

Transfer of stocks to new publisher

Editorial expenses

Difference between income and expenditure

Gain on fluctuations in rates of exchange

Accumulated balance at the end of the year
Less Publisher's commission
1978

$\begin{array}{r}94,521 \\ 16,551 \\ \hline\end{array}$

77,970

41,937

2,639

30,559

$\begin{array}{r}75,135 \\ \hline+\$ 2,835 \\ \hline \hline 9,912 \\ \hline 125,573 \\ \hline\end{array}$
1979

$$
111,588
$$

19,535

92,053

34,297

2,534

3,600

20,570

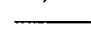

$\$ 30,990$

(4,717)

$\$ 161,287$
1980

98,944

26,677

27,826

3,119

58,543

89,488

$-\$ 17,221$

$(11,186)$

$\$ 132,875$

Table 4. International Tables for X-ray Crystallography
Income
Sale of copies
Less Publisher's commission
Donation
Sale of NBS Monograph

Expenditure

Binding Volume IV

Art work for volume on direct space

Editorial expenses

Computer Trial Project

Difference between income and expenditure

Gain on fluctuations in rates of exchange

Accumulated balance at the end of the year
1978

17,919

5,115

$\begin{array}{r}12,804 \\ 10,985 \\ 37 \\ \hline 23,826\end{array}$

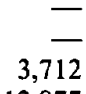

12,077

$\underline{12,077}$
6,024

1979

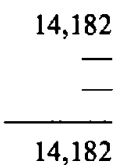

19,097

5,693

1980

13,404

13,404

4,203

1,150

1,315

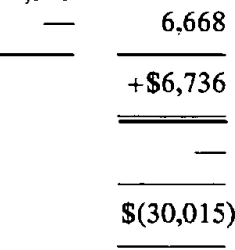

Table 5. Fifty Years of $X$-ray Diffraction

\section{Income}

Sale of copies

Less Publisher's commission

Difference between income and expenditure

Gain on fluctuations in rates of exchange

Accumulated balance at the end of the year
1978

79

16

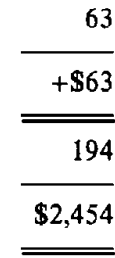

1979
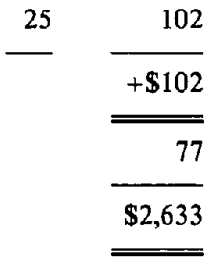

1980

416

125 
and the deficit on this fund account was reduced to $\$ 6704$ by the end of 1980.

The Molecular Structures and Dimensions accounts are shown in Table 8. The Guide to Literature and Volume 9 were published in 1978, Volume 10 in 1979 and Volume 11 in 1980. The net sales income was used to reimburse the University of Cambridge for the publication costs and some of the editing costs incurred by the Crystallographic Data Centre. However, under the terms of the agreement between the Data Centre and the Union, the Union is not required to stand any financial losses which might arise. For 1979 there was an excess of income over expenditure, because the publication costs of Volume 9 had been charged to the account in 1978 but no sales income for this volume was received until 1979 , and $95 \%$ of this amount was repaid to the University of Cambridge to help offset their additional editorial costs.

Table 9 gives the accounts for the President's Fund, which was established in 1977. The fund was set up in memory of past Presidents. It is intended for use in emergencies and under special or difficult circumstances, to help crystallographers to take part in the activities of the Union.

Table 10 summarizes the accounts for the General Fund of the Union. This is the fund which is available for the support of scientific activities other than publications. In 1978 and 1979 only $\$ 4555$ and $\$ 1000$ were spent in support of scientific meetings. In 1980 support totalling \$16 280 was given for three schools, on crystallographic computing, materials science and crystal growth. In 1979 the Commissions on Charge, Spin and Momentum Densities and on

Table 6. Symmetry Aspects of M. C. Escher's Periodic Drawings

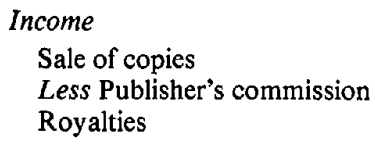

$\begin{array}{r}815 \\ 674 \\ \hline 1,489 \\ +\$ 1,489 \\ \hline \hline 768 \\ \hline \$ 9,733 \\ \hline \hline\end{array}$

1979 1,431 429 1980

\begin{tabular}{|c|c|}
\hline \multicolumn{2}{|c|}{1979} \\
\hline 1,090 & \\
\hline 218 & 872 \\
\hline & \\
\hline & 1,204 \\
\hline & $+\$ 1,204$ \\
\hline & 330 \\
\hline & \\
\hline & $0 \pi, 20$ \\
\hline
\end{tabular}

Table 7. Early Papers on Diffraction of X-rays by Crystals

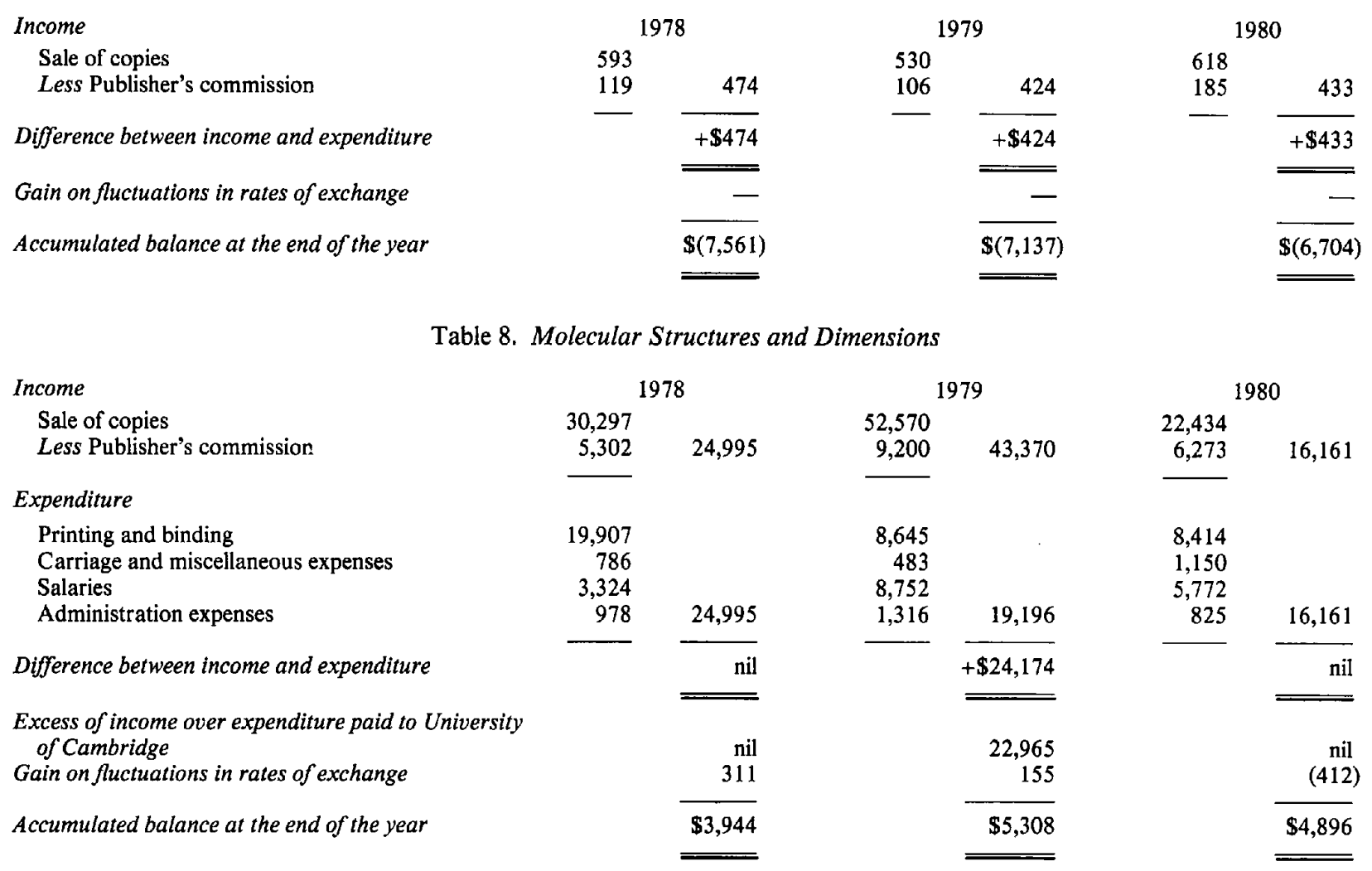


Crystal Growth received financial support to enable them to meet. Other Commissions were able to meet during the triennium without the need for financial assistance from the Union.

Table 11 compares the fund's accounts for the triennium with the budget approved by the Eleventh General Assembly. Table 11 shows a favourable variant of $\$ 41623$ from the

Table 9. President's Fund

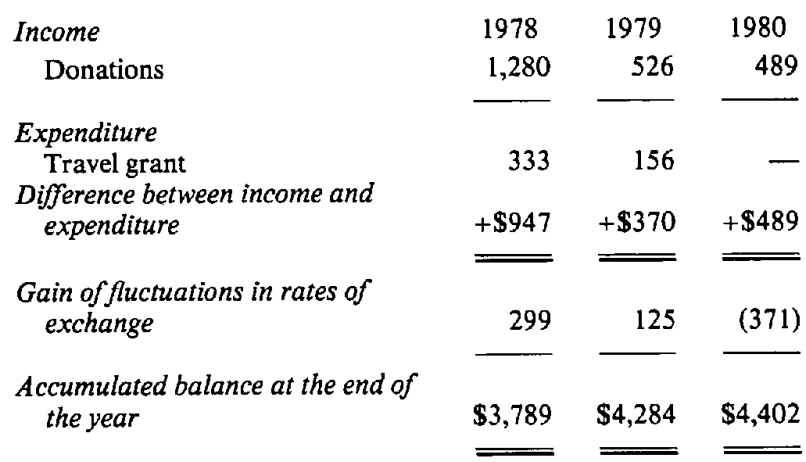

budget. Allowing for the budgeted gain of $\$ 3800$, the actual excess of income over expenditure for the General Fund was $\$ 45423$. The major difference was the yield from investments, which was $\$ 24670$ more than was budgeted for. Since most of the investments held by the Union were in currencies other than US dollars, when the yield from investments is expressed in dollars it is very prone to influence by fluctuations in exchange rates. It has been possible to purchase new investments, to replace the investments which have been redeemed, and to re-establish a more satisfactory reserve against the liabilities of the Union's large publishing commitments. The subscription income was higher than in the budget, because in 1978 two Adhering bodies joined the Union and one increased its Category of Adherence. Additional funds were received from the Unesco Subvention and a grant from ICSU. The sales income and the cost of incidental publications were much lower than in the budget because the Sixth Edition of the World Directory of Crystallographers was not published in 1980. The administration expenses of the Union have increased substantially and were $\$ 34554$ more than budgeted for. This results from the increase in the value of sterling and the high level of inflation over the triennium. The support for

Table 10. General Fund

Income

Subscriptions from Adhering Bodies

Yield from investments and bank accounts

Grant received from UNESCO subvention to ICSU

UNESCO Contract

ICSU Grant

Sale of copies of:

World Directory of Crystallographers; 5th Edition Sundry publications

Donation

Amount charged to Journals and Publications: Acta Crystallographica

Journal of Applied Crystallography

Molecular Structures and Dimensions

Expenditure

Administration

Subsctiptions to ICSU and bodies of ICSU

Executive Committee Meeting

11 th General Assembly \& Congress:

Travel grants

Expenses of Commissions

General Assembly

Executive Committee

Publication of Report

12th General Assembly \& Congress:

Programme Committee

IUCr Representatives on other bodies - travel expenses

Expenses of Commissions

Sponsorship of meetings

Travel grants

Sundry publications

Difference between income and expenditure

Gain on fluctuations in rates of exchange

Accumulated balance at the end of the year
1978

32,560

31,554

7,000

-

37

507

10,230

3,410

489

85,787

44,169

1,378

-

7,680

324

1,924

11,139

-

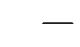

2,163

422

4,555

-

73,754

$+\$ 12,033$

10,710

$\$ 135,496$
1979

44,400

45,992

6,000

4,000

-

842

34

2,500

14,400

4,800

658

123,626

63,875

1,481

10,371
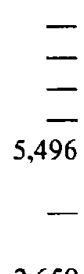

2,650

7,037
1,000

2,000

283

$+\$ 29,433$

4,969

$\$ 169,898$
1980

44,400

39,124

8,000

$5, \overline{000}$

147

114

17,200

5,750

825

120,560

76,472

1,851

13,531

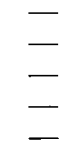

9,268

4,720

16,280

-

122,122

$-\$ 1,562$

(13,071)

$\$ 155,265$ 
scientific meetings is lower than expected because only a few requests were received. It was possible to keep the expenditure on administrative meetings within the budget.

Tables 12 and 13 give a comparison of the Balance Sheet of the Union at the beginning and the end of the triennium. Table 12 shows the fund accounts, whilst Table 13 shows the distribution of the assets. The value of the stocks of unsold copies of the journals and other publications is not included in the assets. The balances in all the accounts, except for Acta Crystallographica and the Journal of Applied Crystallography, have increased since the end of 1977 in spite of the heavy losses sustained in 1980.

The assets at 31 December 1980 , as shown in Table 13, include an amount of $\$ 130905$ for debtors. The largest parts of this relate to amounts due at that date in respect of the publishing operations during 1980, namely $\$ 45282$ from Reidel in connection with Structure Reports and other publications sold by them, and $\$ 3010$ from The Kynoch Press, in connection with International Tables, $\$ 52987$ from the proceeds of the sale of investments, and $\$ 25693$ interest accrued on investments. The creditors include $\$ 45493$ to Munksgaard, in connection with Acta Crystallographica and the Journal of Applied Crystallography. These amounts, due in 1981, and the great majority of the other amounts under debtors and creditors, have since been settled.

The Union's bank accounts are held with the Union Bank of Switzerland in Geneva, the Amsterdam-Rotterdam Bank NV in Groningen, the Bankers Trust Company in New York, the Handelsbanken in Aarhus and the National Westminster Bank in Manchester and Chester. The investments are government or government-backed bonds due to mature at various dates until 1993 and with a total maturity value of Swiss Francs 328000 , plus Netherlands guilders 294000 , plus Deutsche Marks 451000 , plus US $\$ 40000$.

Table 11. Comparison of budget and accounts for the years 1978-1980 inclusive

\begin{tabular}{|c|c|c|c|c|c|c|}
\hline \multirow{2}{*}{ Income } & \multicolumn{2}{|c|}{ Budget } & \multicolumn{2}{|c|}{ Accounts } & \multicolumn{2}{|c|}{ Difference } \\
\hline & & & & & & \\
\hline Subscriptions from Adhering Bodies & 109,060 & & 121,360 & & $+12,300$ & \\
\hline Yield from investments and banking accounts & 92,000 & & 116,670 & & $+24,670$ & \\
\hline Subventions from UNESCO through ICSU & 18,000 & & 25,000 & & $+7,000$ & \\
\hline UNESCO Contract & - & & 5,000 & & $+5,000$ & \\
\hline Sale of incidental publications & 8,640 & & 1,681 & & $-6,959$ & \\
\hline Donations & - & & 2,500 & & $+2,500$ & \\
\hline Gain on fluctuations in rates of exchange & - & 227,700 & 5,519 & 277,730 & $+5,519$ & $+50,030$ \\
\hline Expenditure & & & & & & \\
\hline Administration & 92,200 & & 126,754 & & $+34,554$ & \\
\hline Subscriptions to ICSU and bodies of ICSU & 5,500 & & 4,710 & & -790 & \\
\hline Scientific meetings & 64,000 & & 50,490 & & $-13,510$ & \\
\hline Administrative meetings & 52,000 & & 50,070 & & $-1,930$ & \\
\hline Cost of incidental publications & 10,200 & 223,900 & 283 & 232,307 & $-9,917$ & $+8,407$ \\
\hline Favourable variant from budget & & & & & $\$ 41,623$ & \\
\hline Estimated profit & & & & & 3,800 & \\
\hline Excess of income over expenditure & & & & & $\$ 45,423$ & \\
\hline
\end{tabular}

Table 12. Balance Sheet, Fund Accounts

\begin{tabular}{|c|c|c|c|}
\hline & 31 December 1977 & $\begin{array}{l}\text { Profit on } \\
\text { fluctuations } \\
\text { in rates of } \\
\text { exchange }\end{array}$ & 31 December 1980 \\
\hline Acta Crystallographica & 280,118 & 24,218 & 213,582 \\
\hline Journal of Applied Crystallography & 59,073 & 3,586 & 47,718 \\
\hline Structure Reports & 112,826 & 3,443 & 132,875 \\
\hline International Tables & $(52,133)$ & - & $(30,015)$ \\
\hline Fifty Years of $X$-ray Diffraction & 2,197 & 44 & 2,697 \\
\hline Escher Drawings & 7,476 & 110 & 11,738 \\
\hline Early Papers & $(8,035)$ & - & $(6,704)$ \\
\hline Molecular Structures and Dimensions & 3,633 & 54 & 4,896 \\
\hline General Publications & 52,008 & 1,641 & 53,649 \\
\hline Total of publication accounts & $\$ 457,163$ & $\$ 33,096$ & $\$ 430,436$ \\
\hline General Fund & 112,753 & 2,608 & 155,265 \\
\hline President's Fund & 2,543 & 53 & 4,402 \\
\hline Total accumulated balance & $\$ 572,459$ & $\$ 35,757$ & $\$ 590,103$ \\
\hline
\end{tabular}


Table 13. Balance Sheet, Assets

31 December 197731 December 1980

\begin{tabular}{|c|c|c|c|c|}
\hline \\
\hline \multicolumn{5}{|c|}{$\begin{array}{l}\text { Current assets } \\
\text { Cash at banks: }\end{array}$} \\
\hline Current Accounts & 56,540 & & 29,690 & \\
\hline $\begin{array}{l}\text { ings Accounts } \\
\text { Cash with Union }\end{array}$ & 81,251 & 137,791 & 35,114 & 64,804 \\
\hline officials & & 2,967 & & 7,138 \\
\hline Debtors & & 178,595 & & 130,905 \\
\hline Subscriptions due & & 1,820 & & 5,180 \\
\hline & & 321,173 & & 208,027 \\
\hline Deduct Creditors & & 65,730 & & 151,018 \\
\hline Net current assets & & 255,803 & & 57,009 \\
\hline \multicolumn{5}{|l|}{ Fixed assets } \\
\hline \multicolumn{5}{|l|}{ Investments at market } \\
\hline $\begin{array}{l}\text { Depreciation/ } \\
\text { (Appreciation) in } \\
\text { value }\end{array}$ & $(17,746)$ & & $(27,158)$ & \\
\hline At cost & 315,195 & & 527,843 & \\
\hline Office equipment & 1,461 & & 5,251 & \\
\hline \multirow[t]{2}{*}{ Total fixed assets } & & 316,656 & & 533,094 \\
\hline & & $\$ 572,459$ & & $\$ 590,103$ \\
\hline
\end{tabular}

$£ 300008 \frac{1}{4} \%$ UK Treasury Loan $1987 / 90$ was sold in December 1980 and nearly all the remaining bonds were sold in January and February 1981 in anticipation of the expenses in establishing the in-house typesetter for the journals.

As an association incorporated in Switzerland, the Union is exempt from Swiss Federal and Geneva Cantonal Tax. Under the terms of the United Kingdom Switzerland Double Taxation Agreement 1967, whilst present circumstances obtain, all income arising within the United Kingdom is not subject to United Kingdom tax.

\section{Appendix C: In-house computerized typesetting system}

The IUCr is by statute a publishing scientific union. It has since 1948 been engaged in publishing activities. The founding fathers of our Union were convinced that it should own and consequently control its own journals and other publications in order to obtain a high degree of independence.

The Union has achieved this goal by publishing the journals Acta Crystallographica and Journal of Applied Crystallography, the reference works Structure Reports and International Tables for X-ray Crystallography Vols. I-IV, plus a number of books, e.g. Fifty Years of $X$-ray Diffraction, Escher Drawings, Early Papers, and several other special publications, too numerous to list here. The IUCr publications have, in general, been successful, both from the scientific and from the financial point of view. The Union has thus been able to accumulate a small capital that has allowed it to operate with a high degree of independence of commercial interests.
Over the years, the activities of the Union gradually increased to such an extent that it became necessary to employ a full-time Technical Editor in 1962. Later on, several assistants had to be added. The administrative work increased as well, and the Union had to employ a full-time Executive Secretary in 1969. At present, the IUCr is employing nine persons. Their salaries and other expenses in running the IUCr offices in Chester have to be covered by income from the publications except for part of the administrative expenses which are covered by the General Fund.

During the past ten years, printing costs have increased sharply in most countries. Typesetting is the main expense in producing a scientific journal of limited circulation like Acta Crystallographica. Both the Commission on Journals and the Executive Committee have therefore considered various possibilities for keeping typesetting expenses within bounds. As most crystallographers are very computer-minded, it seemed reasonable to consider the possibility that the Union should proceed towards the installation of a fully computerized in-house typesetting facility. The IUCr had successfully established its own journals and other publishing activities, and the decrease in the price for computing capacity coupled with the developments of phototypesetters indicated that it would be possible even for a comparatively small enterprise like the IUCr to go into the typesetting business. In order to examine the feasibility in depth, the Executive Committee appointed a Sub-committee on InHouse Composition. The sub-committee was set up by the Executive Committee at its meetings in Warsaw in August 1978 and originally comprised Professor S. E. Rasmussen (Chairman), Dr S. C. Abrahams, Dr J. N. King and Dr D. W. Penfold. Mr Ewald Skov Jensen, Associate Professor in Computer Science at the Regional Edp-Centre at the University in Aarhus, was later appointed to the subcommittee after a postal ballot, in accordance with the Executive Committee's decision that a computer scientist might be added to the sub-committee. Later on, the sub-committee enlisted the help of a professional consulting firm.

The sub-committee presented a report to the Executive Committee in August 1980 and arrived at the following conclusions:

(i) Typesetting systems meeting the Union's requirements were available.

(ii) A cost justification analysis showed that considerable savings should be possible by investing in a suitable system.

(iii) The average time taken to produce an issue of a Union journal could be reduced by about 5 weeks.

The full report contains a detailed analysis of a number of systems, and an extensive analysis of development, capital and running costs of a system which could meet the Union's demands for a quality and capacity. The report concludes that it would be advantageous for the Union to purchase a system with a capacity that could satisfy the needs of the IUCr.

The Executive Committee empowered the President and the Treasurer to decide whether or not the Union should go ahead with the in-house project. There was some concern in the Committee about the large investment $(£ 170000)$ and about adding more staff to the Union's pay-roll. 
As the evidence available indicated that it would be advantageous to start the project, I approved the renting of suitable premises in Chester. I also started negotiations with a supplier of a system, and it was established that suitable operators were available in the Chester area.

As the IUCr finances had been in reasonably good shape for some years, I was for some time confident that it would be possible for the Union to finance the in-house project. There were, however, already during the summer of 1980 warning signs which indicated that caution was needed, but I did not take enough notice of these signs.

The accounts for 1980 which became available at the end of March 1981 show a heavy loss, about $\$ 250000$, on the IUCr operations during 1980 . This loss practically wiped out the possibility of the Union going ahead with the in-house project without help from outside agencies.

The main loss, $\$ 168000$, has been on Acta Crystallographica. Since the financial state of the IUCr has always been closely tied to the finances of $A c t a, I$ have looked into its past financial history which I summarize in the Figs. 1, 2 and 3.

In Fig. 1 I depict the development in subscription prices, size of the journal and in number of subscribers. The subscription prices are given in Danish Kroner, not a very stable currency. The prices from the early nineteen-fifties should probably be multiplied by a factor of ten for comparison with current prices. The number of subscriptions increased steadily until 1967 where it reached a peak value of 2365 . Since then, the number of subscriptions has decreased steadily, although the popularity of the journal with authors submitting manuscripts has increased.

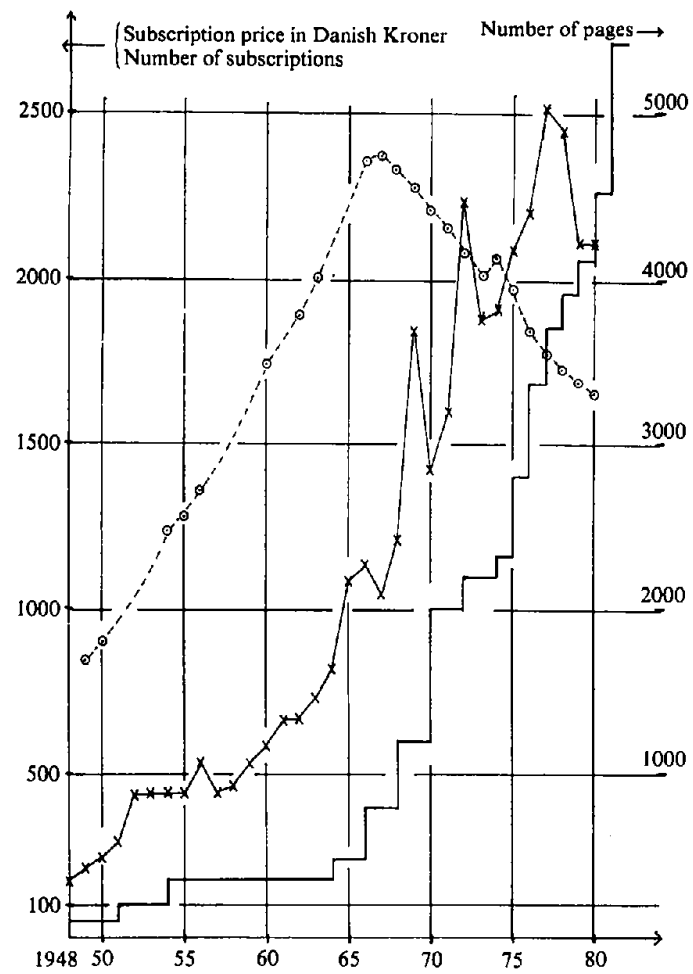

Fig. 1. The development of subscription prices, number of subscribers and number of pages per annum for Acta Crystallographica from 1948 to 1980 . Subscription price in Danish kroner -, number of subscriptions $\odot$, number of pages per annum $x$.
There appears to be little correlation between subscription price and number of subscriptions. Percentagewise, price increases have been rather modest for a number of years and if converted to other currencies like the US $\$$ and the pound the prices have been practically constant for the past few years.

Fig. 2 shows profits and deficits for Acta over the years, expressed in US \$. Evidently, it has always been difficult to arrive at a stable financial situation for Acta. From 1948 to 1968 the balance is negative ten times out of twenty. Fig. 3 shows profits and deficits as percentages of the yearly turnover. Expressed in this way, the fluctuations look rather drastic.

The main cause for the unhappy financial development during 1980 is the increase in exchange rate of the British pound sterling against most other European currencies, particularly against the Danish krone. Fig. 4 shows the variation of the pound/krone ratio over a ten-year period. For a number of years, there was a steady decrease in this ratio. This did not, however, influence the Acta accounts greatly. The income and the bulk of the expenditure, printing, were both in the Danish currency. The technical-editing costs were in sterling, but they only amounted to about $13 \%$ of the total costs and the decrease of the pound was in favour of Acta. In 1975, it was decided to move the printing of Acta from Denmark to Britain to take advantage of the then low costs in the British printing industry. The British printer took over in 1977 and as a result increases in subscription prices were kept at a low level for a few years, although inflation in Britain was high and the printing expenses rose rather rapidly. The pound/krone ratio was fairly stable (within $10 \%$ ) for about three years, but during 1979 the pound began to increase in value in spite of the fact that British

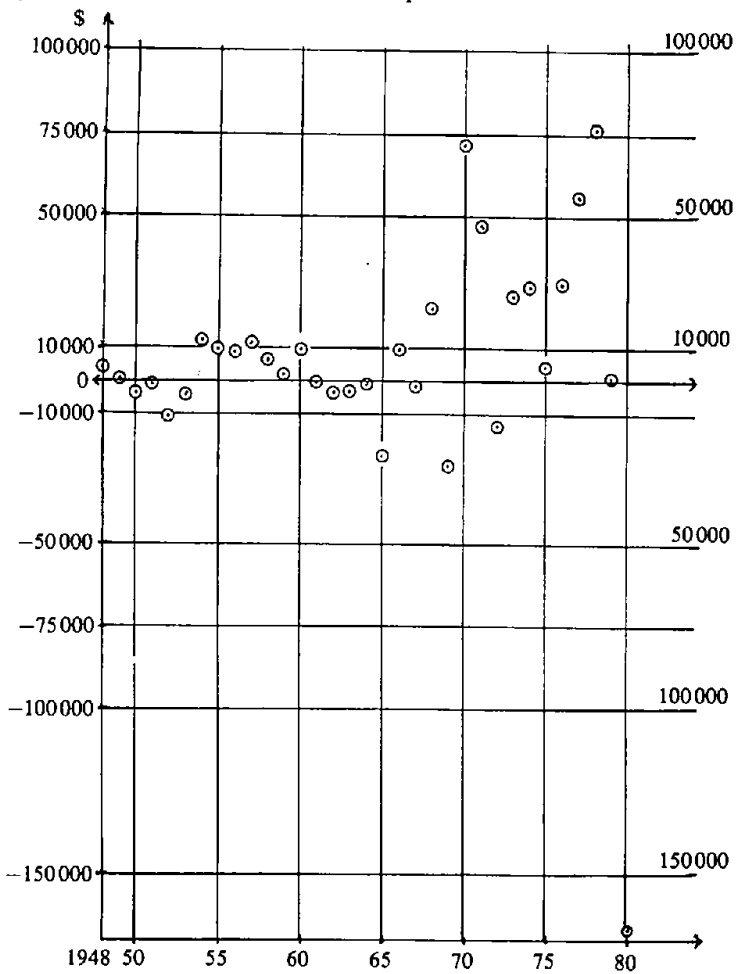

Fig. 2. Profits and deficits for Acta Crystallographica from 1948 to 1980 , expressed in US \$. 
industrial production was decreasing. When the Acta subscription prices for 1980 were fixed in 1979, the pound/krone ratio was 11 . Early in 1981 it had increased to 15.4. During $198 \mathrm{I}$ the ratio has fluctuated between 15.4 and 14.3. The US $\$$ and the pound are normally somewhat correlated and the dollar exchange rates increased slowly with the pound for some time. This spring, however, the US S increased rather dramatically in value, $29 \%$ against the Danish krone in about five months.

The unusually rapid increases in the exchange rates have been especially disastrous because we have few possibilities of counteracting such developments. One way of safeguarding the Union against harmful effects of fluctuations in exchange rates is to make sure that income and the bulk of expenses are in one and the same currency.

About one year ago, the assets of the IUCr totalled about $\$ 700000$ or $\$ 300000$ when converted to one currency alone. However, our bonds, which were mainly in Deutsch Marks, Dutch Guilders and Swiss Francs, only yielded

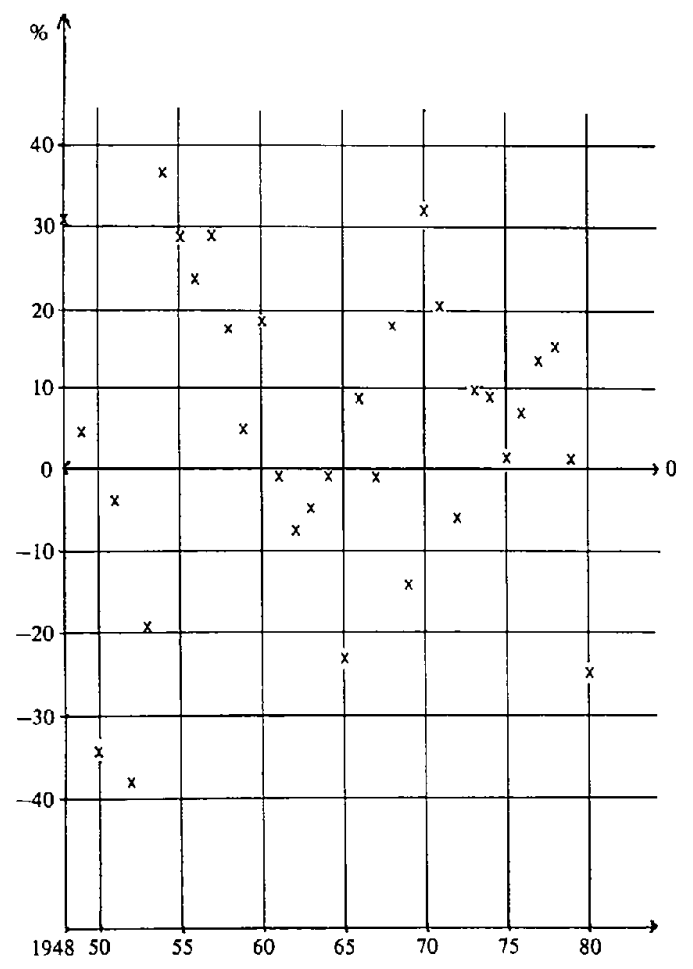

Fig. 3. Profits and deficits for Acta Crystallographica from 1948 to 1980 , expressed as a percentage of the yearly turnover.

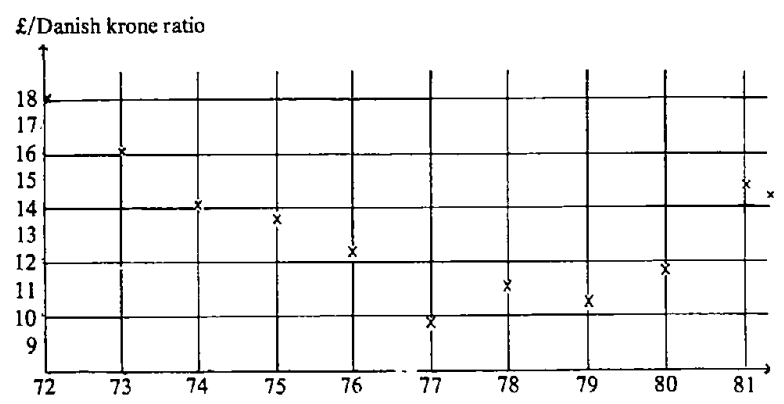

Fig. 4. The variation of the porm tc..ing/Danish krone ratio from 1972 to 1981 .
$£ 230000$ when they were sold early in 1981. Unfortunately, the sale took place at the peak value of the pound. It was necessary in any case to sell at least part of the bonds in order to cover the deficit of the 1980 operations, and I still hoped to be able to find ways and means for starting the in-house typesetting project because it appeared to be the best way of building up new reserves.

The main problem for doing so was lack of capital. We did not have enough reserves to solve our cash-flow problems during 1982 and maybe part of 1983 if we were to start the in-house project in 1981. The President, Professor N. Kato, and I have tried to raise additional capital to overcome the cash-flow problems. Professor Kato has successfully raised a donation of $£ 12000$ from Japanese crystallographers and has raised a bank guarantee for another $£ 16000$ from other sources. I have obtained bank guarantees for $£ 40000$ from our publishers, Munksgaard and Reidel, and I have also sought other sources for loans or guarantees but without success.

The President has suggested that the Union solicit donations from the crystallographers all over the world as he did in Japan. We cannot, however, go ahead with the in-house project this year even if we do get significant donations, because the money will be coming in too late.

I have received much help and advice on the problem of the in-house project from the President, The Vice-President, and other members of the Executive Committee, from $\mathrm{Dr}$ S. C. Abrahams, and from Drs King and Penfold of the Chester staff. In spite of all the efforts of a great number of people, I have found that I cannot after all recommend that the IUCr go ahead with the in-house project because the financial situation is not sufficiently safe. My main worry is the constant decrease in the number of subscriptions to Acta. Although subscription prices when corrected for inflation have hardly increased for several years, we have not succeeded in stabilizing the circulation of Acta. Even with a constant number of subscriptions it would be necessary to increase prices for 1982 and onwards by about $50 \%$ if we want to keep the present standard of printing.

It will be rather expensive to back out of the project. I have already employed two operators who have again had to be told that they had better seek other jobs. I have also approved many expenses such as training of Dr Penfold, fees to consultants, expenses in connection with acquiring new premises, and we may be liable for some payments to Shefra Graphics, the company which has imported the system that we intended to buy. A more cautious and conscientious Treasurer would have avoided such expenses by stopping the project already at the beginning of 1981 , or better by never initiating it.

The fluctuation in exchange rates makes it difficult to avoid financial risks in operating an international scientific union. The main problem is, however, the dwindling support given to IUCr publications. Although the number of entries in the World Directory of Crystallographers has increased steadily for each edition ( 8128 in WDC-6), the sale of $\mathrm{IUCr}$ publications is decreasing. In the very first issue of Acta Crystallographica, Professor Ewald emphasized the fact that Acta belongs to the crystallographers themselves. If crystallographers do want to keep their own, independent publications they must support them by insisting that their libraries, institutions, companies, etc. do purchase IUCr journals and other publications. Sales to as many individual 
crystallographers as possible are highly desirable too, but I realize that prices are prohibitive for large-scale sales to private individuals. However, we could, on the average, halve the prices if we could double the sales!

Although computer typesetting can yield high-quality printing at competitive prices, we must as crystallographers ask ourselves the question if we are prepared to pay for quality. Low-cost, low-quality printing is available, the 'electronic journal' is under way and data bases are already in part replacing printed reference works.

While the IUCr is, I hope, recovering from the financial blow received in 1980 and 1981, it must follow the development in the printing and the publishing trades with great attention and care. I sincerely hope that the IUCr will continue with vigour in the publishing trade. A large number of important and scholarly works would have remained unpublished without the support of the Union.

9 July 1981.

SVEND ERIK RASMUSSEN

\section{Appendix D: Reports of the Commissions of the Union}

\section{(a) Commission on Journals}

Acta Crystallographica and the Journal of Applied Crystallography have been produced on or close to schedule throughout the last triennium, except for several months of industrial dispute at one of the printers. The total output of journal pages decreased over the triennium by about $12 \%$, with Section A of Acta Crystallographica experiencing the only slight increase. Extensive efforts have been made to maximize the density of information published, consistent with clarity. Standards for the acceptance of papers have continued to rise as their application has become more uniform. Mean publication times, between the published date of acceptance and the nominal date of issue, have been reduced to five months for both sections of Acta Crystallographica and for the Journal of Applied Crystallography: the mean publication time for Section B in 1977 was 6.7 months. The Index to Acta Crystallographica has been expanded to five separate sections, allowing information to be retrieved more readily than previously. Papers from 55 different countries have been published.

Subscription rates have increased about $37 \%$ over the triennium, with a loss in the number of subscribers to Acta Crystallographica of $7 \%$ for Section A and $8 \%$ for Section B. No subscriptions to the Journal of Applied Crystallography were lost.

The problem of reconciling escalating production costs with an eroding subscription base faces all publishers. The most effective method for controlling the rapid rise in commmercial composition charges is to install and operate an efficient in-house composition system. Following the recommendation of the Commission and acceptance by the Executive Committee in Warsaw to move with all reasonable speed toward establishment of such a system, a working party was set up to identify the most effective operation among those available. In addition to reducing present composition costs and their future rate of increase, the new system is expected to result in shorter publication times, reduced incidence of typesetting errors, automatic indexing, enhanced flexibility of technical editorial operations, advance use of abstracts and titles and closer interaction with the crystallographic data bases.

Resignations from membership in the Commission were received from $H$. Bärnighausen, J. B. Cohen, J. M. Cowley, J. C. Joubert, E. C. Lingafelter, Z. G. Pinsker, S. Takagi, P. J. Wheatley, P. M. de Wolff and M. M. Woolfson. Appointments to the Commission during the triennium include R. Colella, T. A. Hamor, M. Hospital, S. Jagner, G. Kostorz, Y. Saito, M. Schlenker, V. I. Simonov, D. H. Templeton, H. L. Yakel and B. T. M. Willis. M. Hart was appointed Editor of Journal of Applied Crystallography to succeed R. A. Young from the Eleventh General Assembly.

\section{May 1981. \\ S. C. Abrahams, Chairman M. HART, Co-Chairman}

\section{(b) Commission on Structure Reports}

The three-year period has involved steady co-editorial work resulting in the publication of one $A$ and one $B$ volume each year. The A volumes have appeared approximately one year after the end of the calendar year covered in the volume, and the B volumes about two-and-one-half years after the year covered. These would seem to represent minimum periods, to allow for availability of all the primary publications, preparation of reports, and production of the volumes.

Volumes $41 \mathrm{~B}$ and $42 \mathrm{~A}$ were published in 1978, 42B and $43 \mathrm{~A}$ in $1979,43 \mathrm{~B}$ and $44 \mathrm{~A}$ in 1980 , and $45 \mathrm{~A}$ in early 1981 ; Volume 44B should appear later in 1981.

Minor changes in format were implemented in 1978 to increase the information density and keep the size of the volumes from becoming too large. This has resulted in a stabilization of the size of the A volumes, where the number of reports is now fairly constant from year to year. The number of organic reports in the $B$ volumes however continues to increase (now more than 2200 papers per year, many with several crystal structures each), so that the effect of the format change has already been nullified for these $B$ volumes.

In 1980 D. Reidel became the publisher for Structure Reports.

27 April 1981.

J. Trotter, Chairman

\section{(c) Commission on International Tables}

\section{Present Edition}

The present edition of International Tables (Volumes I to IV) continues to sell well, as can be seen from Table I. The supply of Volume I was exhausted in 1980, that of Volume III is close to exhaustion.

Table I. Sales of International Tables

Volume

Date of publication

Date of reprinting

Number of copies sold up to 31 December 1980

Number of copies sold between 1 January 1978 and 31 December 1980

Stock at 31 December 1980

$\begin{array}{ccrc}\text { I } & \text { II } & \text { III } & \text { IV } \\ 1952 & 1959 & 1962 & 1974 \\ 1965,1969,1977 & 1967,1972 & 1968 & - \\ 9501 & 8250 & 7443 & 2928 \\ 720 & 516 & 511 & 733 \\ \text { Nil } & 367 & 113 & 1039\end{array}$




\section{New Edition of International Tables (Volume A)}

In 1978 the Commission held meetings in Aachen in May and November, and several during the Warsaw Congress in August. These meetings were devoted to data checking, lay-out problems and to discussion of the Introduction. At the Warsaw Congress a new Commission was formed, consisting of ten members who are engaged in completing Volume A of the new edition. In December 1978 D. S. Fokkema obtained the complete print-out of the 17 plane groups and the 230 space groups. With this achievement his work for the new Tables was terminated.

In January and February 1979 a first page make-up for all groups was prepared at Aachen and copies were distributed to all members of the editorial committee. In March some contributors met at Aachen to check and discuss the lay-out and to continue work on the Introduction.

During the summer the print-out was checked and the final corrections and additions were made to the space-group diagrams. In September and October 1979 the complete corrected material was sent to the Union's Technical Editor, D. W. Penfold.

During 1980 the final page make-up for the plane-group and space-group tables was prepared. In October once more copies were distributed to all members of the editorial committee. The results of this final proof-reading were processed by the editor early in 1981 and transmitted to Chester in February 1981. The tables and diagrams for the 17 plane groups and the 230 space groups comprise about 630 printed pages.

Throughout the triennium extensive work on the manuscripts for the Introduction continued. By April 1981, about $85 \%$ of the material was completed and transmitted to Chester for printing; each section was extensively discussed and had undergone several rounds of checking and rewriting. Completion of the remaining few sections is scheduled for May and June 1981. The Introduction consists of about 500 typewritten pages, corresponding to about 200 printed pages.

It is hoped that a complete copy of the Tables and the Introduction will be available at the Ottawa Congress in August 1981.

16 April 1981.

TH. HAHN, Chairman

\section{(d) Commission on Charge, Spin and Momentum Densities}

The Commission has continued to initiate and coordinate studies of various aspects of charge density distributions, especially those of direct interest to the crystallographic community.

\section{Sagamore VI Conference}

The focal activity of the Commission was the Sagamore VI Conference held at Mont Tremblant, Canada, in August 1979 under the chairmanship of Professor V. H. Smith. It was attended by more than one hundred participants; one successful innovation was the institution of a preliminary day of tutorial lectures. At the conference momentum density studies were particularly strongly represented and improvements in accuracy and interpretative techniques were evident. On the other hand, magnetization density studies were poorly represented; it is hoped that this particular deficiency will be remedied at Sagamore VII which will be held in Japan immediately prior to the International Magnetism Meeting. The conference chairman will be Professor Y. Saito.
The Mont Tremblant conference provided an opportunity for the Commission to report on the progress of projects formulated at the Sagamore V conference at Kiljava and at the Warsaw Congress, and to consider suggestions for new projects. A résumé of current projects is given below.

\section{Projects}

(a) The Oxalic Acid Project. Currently this collaborative investigation of charge density in oxalic acid dihydrate is the principal project of the Commission. Two neutron diffraction analyses have been carried out at the Institut Laue-Langevin by Dr R. H. H. Feld and Dr M. S. Lehmann, and a further analysis on the same crystal was made at Brookhaven National Laboratory by Dr T. F. Koetzle and Dr R. K. McMullan. More than ten participants distributed over eight countries are now involved in X-ray studies and a committee of two - Dr S. Harkema and Professor E. D. Stevens - have been requested to examine and review the X-ray studies as they accrue. Two calculations of the charge density which are in mutual agreement (one by $\mathrm{Dr} H$. Johansen and the other by Professor E. D. Stevens) are available for comparison. It is hoped that further theoretical contributions will be forthcoming. Participants in the project are kept in touch by newsletters circulated by the project coordinator, Dr E. N. Maslen.

(b) Data Bank. At Sagamore VI there was extensive discussion of the potential value of a data bank for charge-density studies. Such a bank would hold experimental data, processing parameters, etc., from diffraction studies of charge density distributions. Dr M. S. Lehmann (consultant to the Commission) was asked to investigate the practicalities of such a venture. The current position is that as a result of his initiative such a data bank has now been set up at the University of Erlangen by Professor H. Burzlaff: members of the Commission will sit on the advisory committee.

(c) Correlated wavefunctions. In view of the demand for correlated wavefunctions in charge-density studies Dr P. Becker is investigating available formulations with a view to establishing whether Nesbet's functions satisfactorily avoid the need for full configuration-interaction calculations.

(d) Theoretical calculations of form factors and Compton profiles. The object of this project is to compare the accuracy of charge density parameters derived from a variety of models for a wide range of crystalline systems. Professor V. H. Smith, the project coordinator, will report on it at the Ottawa Congress.

(e) Vanadium project. A new project has arisen from the suggestion that one material should be studied with as many of the experimental charge density techniques as possible. It is hoped that a consistent interpretation of the results on charge, magnetization and momentum densities will then be possible. The chosen material is vanadium and the project is to be coordinated by Dr P. J. Brown.

Finally the Commission has been involved in the planning of no less than three microsymposia for the Ottawa Congress. We trust that these sessions will reflect the interest of the crystallographic community in the work of the Commission.
2 April 1981.
K. V. J. KURKI-SUONIO, Chairman M. J. COOPER, Secretary 


\section{(e) Commission on Crystal Growth}

The major decision of the Commission in the last three years was to expand its activities in the field of materials research. The main reasons leading to this decision are that growth conditions and therefore growth mechanisms have a strong influence on crystal properties, so that one cannot thoroughly investigate the one without the other. The study of the properties of many kinds of crystals used as electronic materials is very important for present-day materials research. Crystal growth under controlled conditions is an important aspect of the materials science of electronic materials. In the coming decades the classical disciplines like crystallography, solid-state physics or (solid-state) chemistry will have to diversify their scope and increase their interdisciplinary activities. The Commission on Crystal Growth feels that with the expansion of its activities to cover fundamental and applied materials research connected with crystal growth, it may contribute to this expansion of crystallography in new fields. In order to maintain the necessary coherence between scope of activities and name, the Commission asked that the name be modified by the Executive Committee to 'Commission on Crystal Growth and Characterization of Materials' and hopes that this will be approved by the General Assembly in Ottawa.

In agreement with this decision the following activities have been undertaken in the joint field of crystal growth and materials research:

(a) An open Commission meeting at the Fifth European Crystallographic Meeting in Copenhagen, August 1979.

(b) The Sixth Course of the International School of Crystallography 'New Crystallographic Perspectives in Materials Science', April 1980, Ettore Majorana Centre for Scientific Culture, Erice, Italy. This course was organized in collaboration with the Commission on Crystallographic Teaching. About 120 participants attended this school where lectures were aimed at diminishing the gap between the classical university education in crystallography and the actual tasks confronting young crystallographers in solidstate research and materials science.

(c) Two microsymposia at the XIIth Congress in Ottawa under the general headings 'Materials Science and Crystallography' and 'Crystal Growth and Characterization'.

(d) An International School on 'Synthesis, Crystal Growth and Characterization of Materials for Energy Conversion and Storage', New Delhi, 12-23 October 1981.

Work on the programme and organization of $(c)$ and $(d)$ is still in progress. The Commission also held closed meetings at the meetings in Copenhagen and Erice.

29 April 1981.

E. KaLDIS, Chairman

\section{(f) Commission on Crystallographic Apparatus}

The Commission met twice during the XIth Congress. The following consultants were appointed: D. C. Creagh, W. H. de Camp, M. Elder, L. D. Jennings, P. Kierkegaard, G. Lundgren, O. S. Mills and S. Szarras, who were all involved in Commission projects. It has not been possible to hold any in-person meetings since then so that all matters have been dealt with by correspondence. This has sometimes proved to be an unsatisfactory state of affairs particularly as the responses from Members and Consultants have in cases been slow. However Commission activities have generally proceeded as planned.

\section{Projects and Publications}

1. Microdensitometer Project (S. Abrahamsson, P. Kierkegaard, G. Lundgren)

A series of carefully prepared precession photographs have been measured microdensitometrically by several laboratories. The data have been analysed in terms of several parameters and the results have been published $[J . A p p l$. Cryst. (1981). 13, 318-337l. Phase two of the project concerns a comparison between data from the same crystal recorded on film and on a diffractometer. A first report will be presented at a microsymposium at the XIIth Congress.

\section{Survey of Film Characteristics (M. Elder, O. S. Mills)}

Various properties of X-ray films of some 30 different brands have been evaluated such as relative speed for $\mathrm{Cu} K$ radiation, granularity at different optical densities, fog density, film factor, amount of silver per $\mathrm{cm}^{2}$ of film, characteristic curve, thickness and weight of coating. The speed and fog density have been measured again after a six-month interval. A final report will be given at the XIIth Congress.

\section{New $X$-ray Film}

At an open Meeting of the Commission at the XIth Congress many crystallographers urged the Commission to take action to safeguard the supply of X-ray film, as many manufacturers have indicated that they would no longer market film for diffraction work. The Commission has approached manufacturers on the matter. As a result CEA-verken, of Strängnäs, Sweden have developed a new film for diffraction work. A preliminary study will appear shortly [J. Appl. Cryst. (1981). 14, 256-260].

\section{X-ray Attenuation Project (D. C. Creagh)}

Fifteen sets of silicon samples have been distributed to laboratories which originally indicated their willingness to participate in the project. Since then several more enquiries have been received and additional samples have been fabricated. Some results have already been received and a comprehensive report will be given in connection with a microsymposium at the XIIth Congress.

\section{Polarization Ratio Survey (L. D. Jennings)}

Because of the complex physical state of a typical crystal monochromator it is unrealistic to attempt to calculate its polarization ratio on a theoretical basis. Therefore, it is important to measure the ratio as part of the routine of setting up a diffraction apparatus. Several laboratories have performed such measurements but not always made them available to the Commission Survey. The results of this project so far will be published soon in an IUCr journal.

\section{Radiation Safety Bibliography (S. Martinez Carrera)}

The bibliography of publications dealing with safety shutters and devices, radiation survey techniques and medical aspects of radiation accidents has been completed and distributed by the Commission to all National Committees. 


\section{Radiation Safety Meeting (W. H. de Camp)}

A meeting dealing with radiation safety problems was planned for the Sixth European Crystallographic Meeting in Barcelona in 1980. A survey made in the USA showed that only a few regulatory agencies might attend. As this may indicate that these agencies are unaware of the special safety aspects of diffraction work further attempts will be made by the Commission to bring them together with scientists and manufacturers in the field.

8. Computerized Bibliography on Small-Angle Scattering (R. W. Hendricks)

The possibility of establishing a computer-based bibliography on the subject has been explored but the responses have been rather negative.

\section{Inter-Congress Symposium on Accuracy in Powder Diffraction}

The Commission supported the Symposium held in Washington, D.C., 11-15 June 1979. The meeting was reported to be very successful.

\section{New Projects}

Two new projects have been contemplated but no further action has been taken at present.

(a) Accurate Determination of $X$-ray Intensities on Diffractometers (H. Hope). The methods for experimental determination of electron densities have improved drastically during the last decade. A systematic study of the procedure of obtaining accurate data is therefore considered appropirate. It has furthermore been suggested that an international meeting on the accurate determination of structure factors be arranged with support from the Commission. This will be considered in relation to the activities of other Commissions.

(b) Absolute Intensity Calibration for Neutron SmallAngle Scattering Facilities (R. W. Hendricks, G. D. Wignall). The aim of the project will be to test the reproducibility and comparative accuracy of the various techniques in current use and to clarify the areas of difficulty in absolute intensity calibration.

28 April 1981.

S. Abrahamsson, Chairman

\section{(g) Commission on Crystallographic Computing}

By August 1978 work on the Winter School on Crystallographic Computing planned for India in the winter of $1979 / 80$ had already progressed some way, and this undertaking became the main preoccupation of the Commission until mid 1980. The school attracted 149 students from 19 countries and 22 lecturers from 10 countries gave their services freely. There were many indications that the school was much appreciated and the Commission felt that the undertaking had been well worthwhile. The lectures and much of the exemplary material have now been published in book form, entitled Computing in Crystallography, by the Indian Academy of Sciences for the IUCr.

Although the Commission has not been directly responsible for the Summer School on Crystallographic Computing at Carleton University, 6-15 August 1981, which is arranged by $D r D$. Sayre, it has played a supporting role and members of the Commission have assisted Dr Sayre in making these arrangements.
The Commission has also arranged two Open sessions in the XIIth Congress, in accordance with plans outlined when the Commission met in January 1980.

In collaboration with the Data Commission, proposals have been worked out for a standard crystallographic file structure intended to facilitate the exchange of information in machine readable form between laboratories. A full report on this topic has been prepared by Dr I. D. Brown of the Data Commission, and this will be presented at the XIIth Congress.

At the XIth Congress Professor M. M. Woolfson reported to the Commission that the task of assembling a bank of trial structures for the purpose of testing new developments in direct methods was now in the hands of Dr G. M. Sheldrick, who has since assembled a bank of 23 such structures of varying complexity. The Commission is grateful to $\mathrm{Dr}$ Sheldrick for this service. Dr Sheldrick intends to make these data available on tape from the time of the XIIth Congress.

28 April 1981.

R. DIAMOND, Chairman

\section{(h) Commission an Crystallographic Data}

At the XIth Congress in Warsaw the Commission held two closed meetings and organized two open sessions - on 'Crystallographic Data Systems' and 'Powder Data'. A variety of topics were discussed at the closed sessions and some have been pursued during the subsequent years.

\section{Bibliography of Mathematical Crystallography}

Commission members helped with the checking of Professor Nowacki's compilations and provided further references. The deadline for publication has been relaxed to cover material for 1979-80. Present plans suggest that the IUCr will publish it as a supplementary publication [see Acta Cryst. (1982), A38, 557; J. Appl. Cryst. (1982), 15, 470].

\section{Standard Crystallographic File Structure}

At Warsaw a working party was formed, jointly with the Commission on Crystallographic Computing. This group has developed a format scheme, modified by solicitation of comments, which is now ready as a report for final scrutiny by the Commissions and submission to the Executive Committee.

\section{Standards for Powder Publications}

The report prepared by an ACA sub-committee was circulated to Commission members. While a few people felt it was rather long and detailed, nevertheless it was approved and the Appendix to the report will be published in Union journals [Acta Cryst. (1981), A37, 443-444; J. Appl. Cryst. (1981), 14, 216-217], with the full report available as a special publication of the National Bureau of Standards.

\section{Data Errors in Acta Cryst. Section B}

An analysis was carried out of some 1500 data sets published in Acta Cryst. Section B during the period 1977-78. 300 of these had been carefully checked by Co-editors resulting in an error rate of only $6.5 \%$. The remaining 1200 showed at least one error in $16.4 \%$ of the data sets. It should be noted that the vast majority of these errors are typographic in origin. 


\section{Ottawa Congress}

The Commission is organizing two microsymposia for the XIIth Congress, entitled 'Databases and Data Centres' and 'Powder Data Collection and Analysis'.

28 April 1981.

D. G. WATSON, Chairman

\section{(i) Commission on Crystallographic Nomenclature}

A new procedure for handling major nomenclature problems in specific fields of crystallography was proposed by the Commission in Warsaw, and was accepted by the Executive Committee. The procedure includes the appointment of ad-hoc committees to consider those areas in which there is important nomenclature disagreement. The recommendations of these ad-hoc committees, following review and final acceptance by both the Executive Committee and the Commission, will be binding on all IUCr publications. The first two ad-hoc committees have now been appointed, one on the Nomenclature of Disordered, Modulated and Polytype Structures with A. Guinier as Chairman and G. B. Bokij, K. Boll-Dornberger, D. E. Cox, J. M. Cowley, S. Durovič, H. Jagodzinski, P. Krishna, K. Kuchitsu, P. M. de Wolff and B. B. Zvyagin as members, and the other on the Nomenclature of Symmetry with P. M. de Wolff as Chairman and N. V. Belov, E. F. Bertaut, M. J. Buerger, J. D. H. Donnay, W. Fischer, Th. Hahn, V. A. Koptsik and A. L. Mackay as members. The Chairman of the Commission is an ex officio member of both committees. Both ad-hoc committees have had vigorous exchanges of correspondence and expect to give informal reports of their progress in Ottawa.

A joint committee of the IUCr, IUPAC and IOCG on the Standardization of Nomenclature in Crystal Growth has also been appointed.

7 May 1981.

S. C. Abrahams, Chairman

\section{(j) Commission on Crystallographic Studies at Controlled Pressures and Temperatures}

A study of the reproducibility of the semiconductorconductor transformation in GaAs, which occurs in the region $18 \cdot 0-19 \cdot 3 \mathrm{GPa}(180-193 \mathrm{kbar})$ according to previous investigations, was planned and carried out. GaAs was chosen because the transition can be observed by several means including X-ray diffraction and optical and electrical measurements. A high-purity, non-doped single crystal of GaAs was sectioned and distributed to more than ten laboratories. Both the diamond-anvil cell and the multianvil-type high-pressure apparatus were used for the present round-robin study. The results are being analysed and will be reported at an Open Commission Meeting during the XIIth Congress.

18 May 1981.

S. AкIмото, Chairman

\section{(k) Commission on Crystallographic Teaching}

The Commission was able to meet during the triennium, at the European Crystallographic Meetings held in Copenhagen and Barcelona in 1979 and 1980, where it also organized open sessions with oral presentations and discussions.
The two major activities of the Commission are the organization of Schools and the Pamphlet Project. A Spring School was organized jointly by the Commission and the Commission on Crystal Growth at Erice, Italy, in April 1980 and plans are under way for the organization of further Schools in Latin America and Asia. A Course on the Repair and Maintenance of Crystallographic Apparatus is also being planned.

The first set of ten pamphlets has been published and copies are available from the University College Cardiff Press. A second set is under preparation. The Commission is compiling a list of books on crystallographic teaching.

25 March 1981.

A. AUTHIER, Chairman

\section{(l) Commission on Electron Diffraction \\ 1. Fifty Years of Electron Diffraction}

A book commemorating the 50th anniversary of electron diffraction (432 pages plus indexes) has been edited by $P$. Goodman, with the help of three regional and two specialsubject editors. The book is arranged in chronological rather than subject order and the three sections are The Start (1924-1928), Subsequent Development at Various Centres of Research (1928-1980) and The Present Subject. In addition to the well known solid-state areas of high- and low-energy diffraction, a substantial contribution is incorporated from workers in the field of gas electron diffraction, which was 50 years old in 1980 . These contributions have been collated and edited by $\mathrm{K}$. Hedberg.

The book is being published for the Union by D. Reidel Publishing Company, and is due to appear in time for the XIIth Congress in Ottawa. Work on the other projects of the Commission has had to be curtailed because of preoccupation with the preparation of this book.

\section{Space-Group Project}

This project has advanced considerably towards the end of the triennium mainly as a result of the activities of $\mathbf{L}$. Kihlborg and M. Tanaka. Although the original target of producing a definitive article on space-group determination by electron diffraction has not been met, a very useful and informative result has been a comprehensive compilation of space-group studies, which was initiated by L. Kihlborg and is currently being completed by $\mathbf{M}$. Tanaka. This compilation, listing substances studied in each crystal system together with literature references, will provide a model for any future annual compilations and has a twofold purpose: to provide compact, up-to-date information to workers in the field, and to inform the rest of the crystallographic community. The initial report states that at least 25 space groups have been studied, distributed over 6 crystal systems; undoubtedly the updated report will extend this considerably.

Whilst the stated objective has not been achieved, the first and most difficult step has been taken in this much discussed project, thus making a successful outcome virtually certain.

\section{Structure Factor Project}

The purpose of this project is to promote collaboration between electron diffraction laboratories in the refinement of electron bonding distributions in a few key substances. The responsibilities of the Commission in this are the selection of suitable substances, distribution of standard material to 
participating laboratories, and reviewing the results. The main achievements to date have been: (a) Summaries by D. Smart and C. Humphreys of all available data on silicon and germanium structure factors, showing the way in which critical-voltage electron diffraction measurements can be combined with $\mathrm{X}$-ray measurements to give a very accurate bonding distribution, have been submitted for publication in Acta Crystallographica. (b) In response to requests from interested laboratories, samples of undoped GaAs in (110) orientation, cut from a single boule, were distributed and further samples are still available for distribution. No detailed measurements have been reported as yet.

As with the previous project, it is anticipated that the completion of Fifty Years of Electron Diffraction will allow more development in this important area. Already the existence of the project has led to useful proposals, from solid-state chemists, of materials for study which are relatively inaccessible to other techniques. One example is $\mathrm{Si}_{3} \mathrm{~N}_{4}$, whose space group has recently been determined and for which the structure factors require refinement.

\section{Gas Electron Diffraction Information Service Project}

This project was started in 1977 for the purpose of rapid distribution of information on newly completed work in the field. The project is organized by $K$. Hedberg and the information is compiled by B. Starck at Sektion für Strukturdokumentation, Universität Ulm, Federal Republic of Germany (see the Commission reports for 1977-1980). Six issues have so far been distributed at a regular interval of about nine months to researchers using GED techniques. These issues (total 139 pages) contain references on the geometrical structures of 749 molecules determined by GED and 172 related works.

10 April 1981.

K. Kuchitsu, Chairman

\section{(m) Commission on Neutron Diffraction}

The Commission currently consists of ten members, including the chairman, and five consultants. Most of its activities in the past three years have revolved around the organization of a satellite meeting on neutron scattering and two microsymposia at the XIIth Congress, and the continuation of a variety of projects which are aimed mainly at collection and dissemination of information.

The symposium on neutron scattering will be held at Argonne just prior to the Ottawa Congress, 12-14 August. This meeting has been arranged in cooperation with Argonne National Laboratory, with M. H. Mueller chairing the local committee. The programme will consist of five plenary sessions of invited papers dealing with pulsed neutron research, instrumentation and techniques, small-angle scattering, magnetism and disordered solids, with contributed papers to be presented in poster sessions. There will also be two sessions of a more informal nature dealing with structure refinement and estimation of errors by the Rietveld technique, and new methods and techniques. This will be a particularly appropriate occasion for a neutron scattering meeting, as it will coincide with the dedication of the new intense pulsed neutron source at Argonne. From the responses to announcements, it is anticipated that there will be a high level of participation by the neutron diffraction commmunity. Papers will be published in the American
Institute of Physics, Conference Proceedings Series, edited by G. H. Lander and J. Faber, to appear early in 1982.

The general area of structural crystallography will be covered in more detail at two microsymposia organized by the Commission in cooperation with W. J. L. Buyers at the Ottawa Congress. These will be devoted to phase transitions and incommensurate structures, and monolayers and intercalated compounds, and will emphasize the interactive and complementary nature of neutron and $\mathrm{X}$-ray diffraction and their role in solid state physics research.

The other activities of the Commission have progressed in varying degrees during the current period. There has been only one change to the list of coherent neutron scattering amplitudes maintained by $\mathrm{G}$. E. Bacon. The compilation of incoherent and absorption cross sections started by T. M. Sabine and W. B. Yelon will be reported on at the Argonne meeting. The compilation of Magnetic Structure Data Sheets by $\mathrm{D}$. E. Cox has progressed, albeit at a rather slow pace, and now comprises about 300 entries in two loose-leaf binders. It now seems clear that the principal value of this is as a reference to published data, in contrast to the original intent of circulating data prior to publication, and it would be desirable to devote extra effort to bringing the compilation up to date. A bibliography on neutron scattering and diffraction is being prepared at the Japan Atomic Energy Research Institute in collaboration with $\mathrm{S}$. Hoshino, and a survey of neutron diffractometers and software by $M$. S. Lehmann and $H$. Dachs is in progress and will be completed later this year. The intercomparison project on Rietveld analysis of $\mathrm{Al}_{2} \mathrm{O}_{3}$ powder neutron data, started in the previous period by A. W. Hewat, A. F. Andresen and T. M. Sabine, will be given further consideration at the Argonne meeting, and final plans will be made for publication of the results. The remaining project of the Commission, the Neutron Diffraction Newsletter edited by W. B. Yelon, has unfortunately attracted too few contributions to make publication feasible in the past two years.
6 May 1981.
D. E. Cox, Chairman

\section{Appendix E: Reports of the Representatives on Scientific and Regional Associates}

(a) International Organization for Crystal Growth (IOCG)

Scientific collaboration between the IOCG and IUCr has improved continuously in the last two years as a result of the close exchange of ideas between members of the Commission on Crystal Growth, who have responsibilities in both organizations, and the officers of the IOCG. This unofficial collaboration brought improvements to the following programme of activities:

(a) 4th International Conference on Vapour Growth and Epitaxy, Nagoya, Japan, July 1978.

(b) 6th International Conference on Crystal Growth, Moscow, USSR, September 1980.

(c) International Specialists' School on Crystal Growth, Susdal, USSR, September 1980.

All these meetings had an excellent scientific programme and discussed many fundamental and applied subjects of crystal growth. The Moscow meeting in particular demonstrated, following the example of the Institute of Crystallography of the Academy of Sciences, the tremendous impact 
that crystallography can have not only in solid-state research but also in the economy of a country. From the point of view of the history of science it will be interesting to see if other countries follow this example.

29 April 1981.

E. KALDIS, Representative

\section{(b) European Crystallographic Committee}

The European Crystallographic Committee became a Regional Associate of the International Union of Crystallography by vote of the General Assembly in Warsaw in 1978 . It was deemed likely that adherence to the Union could facilitate attendance at European Crystallographic Meetings sponsored by the committee. Experience at the Fifth European Crystallographic Meeting (ECM-5) in Copenhagen in 1979 and at ECM-6 in Barcelona in 1980 indicated that this hope is being fulfilled.

The Union representative attended the meetings of the European Crystallographic Committee held in August 1979 during ECM-5 in Copenhagen and in July 1980 during ECM-6 in Barcelona. The representative's role at the meetings was to be responsive to matters that concerned the affiliation of the European Crystallographic Committee with the Union. His duties also included making a report to the Executive Committee of the Union concerning matters of affiliation and, in addition, main agenda items and future plans, particularly with respect to forthcoming meetings. No substantive issues concerning the affiliation of the European Crystallographic Committee with the Union have arisen.

14 April 1981.

J. KARLE, Representative

\section{Appendix F: Reports of the Representatives on bodies not belonging to the Union}

(a) IUPAP Commission on the Solid State

The Commission prepared and discussed a proposal to be put to the IUPAP General Assembly (1981) concerning the future of the Commission on the Solid State within the framework of IUPAP. Wide approval was given to the idea of concentrating the activity in areas of physics under the general heading of 'Structure and Dynamics of Condensed Matter', which only slightly overlaps the interests of other IUPAP Commissions, on Magnetism, Semiconductors and Very Low Temperatures. The areas covered by the heading may include: structure and crystallography; defects in solids; metallurgy; surfaces, crystal growth; structural phase transitions; ferroelectricity; lattice dynamics (Raman spectroscopy, neutron scattering); anharmonic effect; thermal conductivity; shock wave in solids; atomic motion in solids (diffusion, hydrogen compounds, muonic effects, superionic conductors, molecular rotation in plastic crystals); tunnelling of atoms; quantum crystals; microscopic properties of liquids; liquid metals, electrolytes; ionic liquids; 'frozen' liquids and glasses; amorphous materials; macroscopic properties of liquids; physical hydrodynamics; instabilities, turbulence; liquid crystals and the various mesomorphic phases; polymers.

The Commission studied the applications for conferences to be sponsored and supported by IUPAP and made appropriate recommendations.
The Commission prepared a list of possible future members of the Commission comprised of experts who are recognized in the above-mentioned fields of physics.

20 March 1981.

A. LÍNEK, Representative

(b) Conference Committee of the European Physical Society

The Committee has met regularly twice a year in various European cities. At these meetings the Committee has considered applications for EPS approval/sponsorship for conferences and schools and has particularly investigated the scientific level of the latter. The Union Representative provided information about European physics meetings for inclusion in the Forthcoming Meetings section in Journal of Applied Crystallography.

The application form for EPS Approval/Sponsorship was reformulated. Continued discussion concerned the question in which the conference organizers are asked to affirm that there will be open access to the conference for physicists from all European countries. The Committee is currently collecting information about past physics conferences using a Post-Conference Questionnaire. In this way statistical data will be available for the organizers of the future conferences. A Guideline for Organization of International Conferences is also being prepared. This Guideline will be a collection of advice, especially of a technical character, helpful for organizers.

The Committee has been informed about preparations for the EPS General Meeting in 1981. It also discussed financial assistance to younger physicists to make possible their attendance at the General Meeting.

The EPS Secretariat published a Europhysics Poster EPS Organized Conferences, which was distributed to physics laboratories throughout Europe.

The problems connected with publishing Europhysics Conference Abstracts were also discussed. Each year the latter includes abstracts from all EPS Organized Conferences. It was concluded that European Conference Abstracts provides fast first-hand information and current awareness of the latest developments in physics in Europe and therefore it was recommended that publication of these abstracts should be supported as far as possible.

24 March 1981.

A. LíNEK, Representative

\section{(c) ISCU Abstracting Board}

In 1978 the Abstracting Board of the International Council of Scientific Unions was showing difficulties both in financing and in administration. In order to deal with these difficulties, the President (M. S. Day) made two suggestions. The first was that the headquarters of the Board would be moved from rue Mirabeau to the building occupied by ICSU in the boulevard de Montmorency. The accommodation would not be as ample, but the cost for rent and services would be reduced by a factor of 4 or 5 . The work required from the General Secretary had been changing over the last few years, and what was required now was an Executive Secretary with administrative qualifications, rather than a paid General Secretary with scientific and technical qualifications. These changes necessitated changes in the Statutes and By-laws, and the opportunity was taken to increase the number of elected officers. Previously there had been only a 
President, but in future there would also be a Vice-President, a General Secretary, and a Treasurer, in addition to the paid Executive Secretary. The dues structure was also revised. and led to a considerable increase in the income from the larger Member Services.

These changes were implemented over the period 19781980 , and it appears that the finances of the Board are now sound, though not as ample as might be desired. The new administrative structure, also, is working well. During the period of implementation there was a reduction in the technical activity of the Board, and no seminars were arranged in 1979 and 1980, though one on 'The on-line revoution in information' had been organized in Paris immediately preceding the Board Meetings in 1978. However, the full scientific and technical programme of the Board has been resumed, and a seminar 'The economics of secondary information" will be held in Atlanta in May 1981, immediately preceding the Full Board Meetings.

1 May 1981.

A. J. C. WILSON, Representative

\section{(d) ICSU Committee on Data for Science and Technolog.} (CODATA)

The Sixth International Conference and Eleventh General Assembly took place in 1978 in Santa Flavia. Sicily. The theme of the conference was the prediction of natural disasters and the prevention of man-made hazards. The Seventh International Conference and Twelfth General Assembly took place in 1980 in Kyoto, Japan. The theme of the conference was the role of data in a dynamic world.

During this period the IUCr delegate was appointed Chairman of the Task Group on Accessibility and Dissemination of Data and later Treasurer of CODATA. He also co-edited a book entitled Data Handling for Science and Technology - An Overview and Sourcebook.

The considerable publication programme of CODATA has continued with the appearance of some further 12 Bulletins. The Directory chapter on crystallography has now been followed by others on hydrology, astronomy and zoology.

CODATA is increasing its activities in the educational field and a number of training courses have been organized, including one chaired by the IUCr delegate in Japan in 1980.

Groups of people in CODATA have been concerned with computer file exchange formats and this activity should be of interest to the IUCr Commissions on Data and Computing.

15 countries and 15 Unions are now represented and the greatly increased size of the Conferences suggests that CODATA is becoming recognized as a most useful forum for data problems common to many branches of science and technology.

28 April 1981.

D. G. WATSON, Representative

(e) ICSU Committee on Science and Technology in Developing Countries (COSTED)

COSTED provides some financial support to scientists from developing countries in order to help them attend scientific meetings or schools. However, the lack of communication between COSTED and the various International Scientific Unions was stressed by many representatives at the meeting of the General Committee of COSTED. which was held in Amsterdam in September 1980 and which was attended by several representatives from the IUCr. COSTED is in the process of developing its programme for the period 1981-1983, and ICSU has recommended that the relations with the various Unions in ICSU should be strengthened.

25 March 1981.

A. AUTHIER, Representative

\section{(f) ICSU Committee on Space Research (COSPAR)}

Like all new scientific fields, materials science in space is struggling to find a direction and, as far as possible, keep itself independent of the many non-scientific influences. The development of a platform under the auspices of COSPAR to discuss the fundamental aspects of the subject has improved scientific contacts and encouraged fruitful discussions. The potential for materials research in space, however, is so far unknown, not only because the new environment presents very severe boundary conditions for experimentation, but also because ballistic-rocket, Apollo and Soyuz flights could not offer the necessary conditions for advanced experimental work. After the Spacelab flights in May 1983, materials science in space should take a considerable step forwards in realizing its aims.

The main conclusion from the existing experiments is that effort must be made to understand the fundamental aspects of this field. Applications without an understanding of the basic phenomena are a very poor investment. The IUCr has fought in the last three years, in collaboration with COSPAR, to make this understood by the various space agencies.

29 April 1981.

E. K ALDIS, Representative

\section{(g) ICSU Committee on the Teaching of Science}

The Committee met in Paris in March 1979 and in Malvern, England, in March 1980, and was represented at the Fourth International Congress on Mathematical Education in Berkeley, California, USA, in August 1980 and at the 18th ICSU General Assembly in Amsterdam in September 1980.

One of the main activities of the Committee has been a discussion of the interaction of mathematics with other sciences at various levels. Joint seminars and workshops are to be organized in 1981. The production of something corresponding to the New Unesco Source Book for Science Teaching is being considered. This may have several forms, each concentrating on the interface between mathematics and a specific science discipline.

25 March 1981.

A. Authier, Representative

\section{(h) ICSU Scientific Committee on Problems of the Environ-} ment (SCOPE)

During the triennium the General Assembly of SCOPE met in Stockholm in June 1979 and the Executive Committee held an open meeting in Brussels in September 1980. The ongoing SCOPE projects were reviewed and the policy for the next few years was formulated. The global biogeochemical cycles of carbon, nitrogen, phosphorus and sulphur have been studied extensively and general surveys have been published. The study of the interaction of these bio- 
geochemical cycles has now been approved and a Steering Committee has been appointed. The ecotoxicology project has continued and an outline of the project on the effects of chemicals in the environment has been approved. Other projects, including fire in the ecosystem, land transformation, dynamics of continental wetlands, a groundwater modelling clearing-house, environmental monitoring and assessment of environmental risk, have been continued.

The involvement of crystallographers in the SCOPE projects seems so far to be very limited. The understanding of the potential value of applied crystallography as a tool for the study of, for example, the biogeochemical cycles, which in many cases include solids, is not widespread. It is important that crystallographers who are in a position to do so make the possibilities of applied crystallography known to their colleagues engaged in SCOPE projects.

5 May 1981.

P. KIERKEGAARD, Representative

\section{Appendix G: Summary of the activities of the Sub-committee on the Union Calendar}

This Sub-committee is a sub-committee of the Executive Committee and therefore, according to Statute 8.1, has no obligation to report to the General Assembly. However, a summary of its activities is given in this Appendix for the information of delegates.

During the period since the Eleventh General Assembly, the Sub-committee has considered many requests for sponsorship and financial support by the Union, and has made recommendations accordingly to the Executive Committee. The following meetings on topics of crystallographic significance have received Union sponsorship. Meetings which also received financial support from the Union are indicated by an asterisk. The list includes meetings held before and after the Eleventh General Assembly which were awarded Union sponsorship by the Executive Committee before the end of that General Assembly. The Union also provided financial support for the Twelfth International Congress of Crystallography.

*International Symposium on Biomolecular Structure, Conformation, Function and Evolution, Madras, India, 4-7 January 1978.

Fifth International Symposium on Organic Solid State, Waltham, USA, 13-16 June 1978.

Fourth International Conference on Vapour Growth and Epitaxy, Nagoya, Japan, 9-13 July 1978.

*International Summer School on Crystallographic Computing, Twente, The Netherlands, 24 July-1 August 1978.

*Conference on Diffraction Line Profile Analysis, Cracow, Poland, 14-15 August 1978.

*Summer School on Diffraction Studies of Non-Crystalline Substances, Pécs, Hungary, 14-19 August 1978.

Sixth International Symposium on Boron and Borides, Druzhba, Bulgaria, 9-12 October 1978.

*Inter-Congress Meeting on Modulated Structures, Hawaii, USA, 22-25 March 1979.

Inter-Congress Symposium on Accuracy in Powder Diffraction, Washington, DC, USA, 11-15 June 1979.

Fifth European Crystallographic Meeting, Copenhagen, Denmark, 13-17 August 1979.

Sagamore VI Conference on Charge, Spin and Momentum Densities, Mont Tremblant, Canada, 19-25 August 1979.
*Winter School on Crystallographic Computing, Bangalore, India, 4-14 January 1980.

*New Crystallographic Perspectives in Materials Science, Erice, Italy, 8-21 April 1980.

Sixth European Crystallographic Meeting, Barcelona, Spain, 28 July-1 August 1980.

Sixth International Conference on Crystal Growth, Moscow, USSR, 10-16 September 1980.

*Fourth International Specialists' School on Crystal Growth, Susdal, USSR, 17-25 September 1980.

Applications of the Mössbauer Effect, Srinagar, India, 13-17 July 1981.

*An International Summer School on Crystallographic Computing, Ottawa, Canada, 7-15 August 1981.

*Neutron Diffraction Conference, Argonne, USA, 12-13 August 1981.

*Crystallography in the Health Sciences; Crystalline Deposits in Human Tissues, Toronto, Canada, 13-14 August 1981.

*Biologically Active Molecules, Buffalo, USA, 26-28 August 1981.

*International School on Synthesis, Crystal Growth and Characterization of Materials for Energy Conversion and Storage, New Delhi, India, 12-23 October 1981.

*The Crystallography of Molecular Biology, Erice, Italy, 17-19 June 1982.

Sagamore VII Conference on Charge, Spin and Momentum Densities, Nikko Kanayo Hotel, Japan, 25-30 August 1982.

Currently under consideration are:

Seventh European Crystallographic Meeting, Jerusalem, Israel, 29 August-3 September 1982.

Fifth European Meeting on Ferroelectricity, Torremolinos, Malaga, Spain, 26 September-1 October 1983.

A list of meetings of interest to crystallographers is published in each issue of the Journal of Applied Crystallography. Attempts to make this list as comprehensive as possible depend to a large extent on the Executive Secretary being informed of relevant meetings by National Committees and individual crystallographers.

\section{Appendix H: Consideration of provision for individual scientists to become members of the Union}

At its meeting in July 1980 the Executive Committee considered the suggestion that provision should be made for individual scientists to become members of the Union.

The Executive Committee set up a small sub-committee, consisting of Dr S. C. Abrahams, Professor H. Neels and Professor S. E. Rasmussen, to explore the proposal.

The sub-committee found that only one international Union, the International Astronomical Union, had arrangements for widescale individual membership. This Union was quite enthusiastic about the arrangement, which kept the Union secretariat in direct communication with nearly all the practising astronomers throughout the world. Members received two issues of the IAU Bulletin each year, the $\$ 4000-5000$ cost of this being borne by the IAU. The method of election appeared to take a good deal of time and effort, and was a disadvantage of the arrangement. IUPAC was also considering individual membership, but no con- 
sensus of opinion had been reached as to its potential value. It might be noted that IAU was more comparable in size with IUCr than IUPAC.

The sub-committee suggested that the potential benefits of individual membership might include:

1. Greatly enhanced identification of individual crystallographers with the objectives of the Union.

2. The possibility of enhancing the status of individual crystallographers.

3. Strongly improving the level of communication among crystallographers.

4. Providing a larger reservoir from which the Commissions can draw when compiling their recommendations to the Executive Committee for new members and when selecting any consultants.

5. Increasing the opportunities for individuals to take part in international experimental research projects.

Among the possible disadvantages of individual membership were:

1. The difficulty of transferring membership dues from countries with non-convertible currency.

2. Apprehensions by national societies that the IUCr may be competing with them for members.

3. Apprehensions that voting rights will be misused by the larger countries.

One of the ways of improving the level of communications amongst crystallographers might be the inclusion of news items concerning crystallographers and current accounts of the work of the Union's non-publishing Commissions in an inexpensively-produced journal containing abstracts of forthcoming articles in Acta Crystallographica and Journal of Applied Crystallography, the proposals for which are being considered by the Commission on Journals.

Whilst difficulties would be experienced in transferring membership fees from countries with non-convertible currencies, such funds might be used to offset the costs of distributing the proposed abstracts journal. It was suggested that any apprehension by national societies that the IUCr might be competing with them for members might be dispelled if the principal objectives of membership were confined to the potential benefits listed above.

Any apprehension concerning voting rights would be eliminated if there were no voting rights associated with individual membership.

The sub-committee and the Executive Committee will be interested to hear the views of the General Assembly on the idea of individual membership.

\section{Appendix I: Budget estimates for the period to the Thirteenth General Assembly; determination of the unit contribution}

(a) Budget estimates

As previously, an estimated budget for the period until the next General Assembly has been prepared for the General Fund only. Since the budget estimates had to be prepared at a time when the decisions on many activities had still to be made, these estimates should be considered with due reserve. With this proviso, and in accordance with Statute 9.3, the Executive Committee presents to the Twelfth General
Assembly the following estimates for the three-year period 1 January 1981-31 December 1983.

Two budgets have been prepared (Table I); the first on the assumption that the in-house typesetting system is established and the second on the assumption that it is not established.

In preparation for the establishment of the system virtually all the Union's investments have been sold, and the proceeds have been placed on deposit terms in sterling with the National Westminster Bank in Manchester. The sale proceeds exceed cost and do not differ significantly from the market value noted in the Balance Sheet at 31 December 1980. All this money will be required to finance the installation of the typesetting system, and therefore the yield from investments and banking accounts for the triennium will be very small. If the typesetting system is established a large deficit is estimated for the General Fund. However, the total operations of the Union over the triennium will have to balance, and it is proposed that this deficit should be balanced by a surplus for the fund accounts for the Union's publications.

Table 1. Estimates for the three-year period 1 January 1981-31 December 1983

(i) In-house typesetting system established

Income

$\$$

Subscriptions from Adhering Bodies

Yield from investments and banking accounts

150,000

Sale of incidental publications $\quad 22,000$

$\$ 224,000$

(1)

Expenditure

Administration

Subscriptions to ICSU and bodies of ICSU

169,600

Administrative Meetings

5,300

Scientific Meetings

53,000

Cost of incidental publications

48,000

20,000

Estimated deficit

$\$ 295,900$ $-\$ 71,900$

(ii) In-house typesetting system not established

Income

$\mathbf{s}$

Subscriptions from Adhering Bodies

Yield from investments and banking accounts

150,000

Subventions from Unesco through ICSU 32,000

Sale of incidental publications $\quad 22,000$

$\$ 294,000$

Expenditure

Administration

169,600

Subscriptions to ICSU and bodies of ICSU 5,300

Administrative Meetings $\quad 53,000$

Scientific Meetings $\quad 48,000$

Cost of incidental publications $\quad 20,000$

Estimated deficit 
The income from subscriptions from Adhering Bodies has been determined on the basis of unit contributions of $\$ 300$ for 1981 and $\$ 360$ for 1982 and 1983. As in the past, the above budget assumes that part of the expenses of the administration ( $\$ 72700$ ) will be charged to the publication accounts. Thus the total expenses of administration are estimated at $\$ 242300$.

Expenses included under 'Administrative Meetings' are those of the Executive Committee meetings, Union representation on other bodies and the printing of the report of the General Assembly. The heading 'Scientific Meetings' includes financial support for scientific meetings organized or sponsored by the Union as well as the expenses of the non-publishing Commissions, the Commission Chairmen and the Scientific Programme Committee for the triennial Congresses of Crystallography. The expenses of the publishing Commissions are charged to the relevant publication.

The Executive Committee is conscious of the need to keep expenses, particularly administrative expenses, to a minimum. However, the Executive Committee is required to meet at least twice during the period between the General Assemblies (By-Law 2.1), and it is felt that these annual meetings are necessary if the Committee is to maintain an effective control over the financial affairs of the Union, particularly with regard to the very large publishing activities which currently involve an annual turnover of nearly $\$ 900000$ and the establishment of the in-house typesetting system.

The steady increase in the size of the journals necessitated larger offices being acquired in Chester. The Union secretariat and technical editing office moved to 5 Abbey Square, Chester, in January 1979.

\section{(b) Unit contribution}

According to Statute $5.10(k)$ the General Assembly has to determine the unit contribution from the Adhering Bodies for the period to the next General Assembly.

The Executive Committee considers it necessary to recommend an increase in the unit contribution to the equivalent of $\$ 360$ from 1 January 1982. On 29 August 1980 the National Committees were informed of the Executive Committee's intention to propose that the currency of the unit contribution should be changed to the Swiss Franc and that a contribution of $\$ 360$ would be equivalent to SwFr 600. Since then the value of the Swiss Franc has dropped with respect to the dollar and a figure of SwFr 730 would currently be necessary to retain a dollar equivalent of $\$ 360$. Because of these recent fluctuations in exchange rates the Treasurer is now less inclined to recommend a change in currency to the Swiss Franc. However, it has not been possible to consult the Executive Committee about the question prior to the despatch of the Agenda papers.

The last time that the unit contribution was increased was at the General Assembly in 1978, when it was raised from $\$ 220$ to $\$ 300$ for 1979,1980 and 1981. In view of the substantial increases in costs in the last three years, and the wish to provide as much financial support as possible to scientific meetings and Commissions, the Executive Commit tee proposes, on the basis of the budget given in Section (a) above, that the unit contribution be increased from 1 January 1982 to the equivalent of US $\$ 360$ for the years 1982,1983 and 1984. The proposal to keep the unit contribution constant for these three years is made in the light of the feelings of delegates expressed at recent General Assemblies, when they preferred this arrangement to the idea of smaller annual increases.

The above proposal is made on the basis of exchange rates in force on 4 May 1981 (US $\$ 1=$ Swiss Francs $2.02=$ UK $£ 0.461=$ Netherlands guilders $2.45=$ German Marks $2 \cdot 20=$ Danish kroner 6.95). Should significant alterations to exchange rates occur before the General Assembly, the Executive Committee may consider it necessary to submit a revised proposal.

\section{Appendix J: A charge for publishing?}

The Executive Committee has been discussing the possibility of having a charge associated with the publication of articles in its journals. This would be strictly a non-mandatory charge, so that non-payment would in no way influence the opportunity to publish in the journals. A relatively modest charge, for example $\$ 100$, honoured by several hundred contributors in the course of a year could be, in effect, a significant donation to the well-being of the publications.

The Executive Committee is interested in soliciting the opinions of the members of the General Assembly on this matter. If there were a sufficiently favourable response, the Executive Committee would feel encouraged to make a detailed study during the coming year.

Therefore, the Executive Committee requests that the members of the General Assembly consider the question of a charge associated with the publication of journal articles and that the members agree to add this question to the General Assembly Agenda.

The Executive Committee has considered the following advantages and disadvantages associated with a publication charge:

\section{Advantages}

(a) Subscription prices could be lowered which would make the journals more accessible for libraries with small budgets.

(b) Personal subscriptions could be made much more affordable for individual crystallographers.

\section{Disadvantages}

(a) For several institutions payment of non-mandatory publication charges is impossible for financial or administrative reasons. Thus, payment of nonmandatory publication charges is open for a limited group of crystallographers only. This might create problems in relations between groups who pay and groups who do not pay publication charges.

There are other advantages and disadvantages that could be discussed and before the Executive Committee studies this problem any further it would like to have this matter discussed informally in a General Assembly session. 


\title{
Statutes and By-Laws of the International Union of Crystallography
}

\author{
as Adopted by the Fourth General Assembly in 1957 and Amended by the Fifth General Assembly in \\ 1960, the Sixth General Assembly in 1963, the Seventh General Assembly in 1966, the Eighth General \\ Assembly in 1969, the Ninth General Assembly in 1972, the Tenth General Assembly in 1975, and the \\ Eleventh General Assembly in 1978
}

\section{Statutes}

\section{Objects of the Union}

1.1. The objects of the Union are

(a) to promote international cooperation in crystallography;

(b) to contribute to the advancement of crystallography in all its aspects, including related topics concerning the non-crystalline states;

(c) to facilitate international standardization of methods, of units, of nomenclature and of symbols used in crystallography;

(d) to form a focus for the relations of crystallography to other sciences.

1.2. For these purposes the Union shall have the power

(a) to adhere to the International Council of Scientific Unions;

(b) to organize international meetings and conferences on subjects falling within the purview of the Union;

(c) to promote international publication of crystallographic research and of crystallographic works;

(d) to set up Commissions or other bodies for special objects;

(e) to initiate, promote and coordinate crystallographic research requiring international cooperation;

$(f)$ to organize Special Projects which shall be financed independently of the regular operations of the Union;

(g) to participate in Joint Commissions with other Unions or other scientific bodies in matters of interest to the Union;

(h) to perform all such other legal acts as are essential for or conducive to the objects of the Union including the constitution or organization of separate or independent bodies having an appropriate legal status;

(i) to receive into association existing regional organizations of crystallographers having substantially the same aims and objects as the Union; these organizations shall be known as Regional Associates of the Union;

$(j)$ to receive into association existing international scientific organizations whose interests overlap with the aims and activities of the Union; these organizations shall be known as Scientific Associates of the Union.

\section{Organization and Legal Domicile}

2.1. Under the name of International Union of Crystallography an Association has been organized and incorporated; it is governed by Articles 60 and following of the Swiss Civil Code and by the present Statutes of Incorporation.
2.2. The duration of the Union is not limited.

2.3. The legal domicile of the Union is in Geneva, Switzerland.

\section{Membership}

3.1. The members of the Union are its Adhering Bodies

3.2. There shall be only one member for each Country.

3.3. In a Country the Adhering Body can be a National Academy, National Research Council or similar body, or a scientific society or group of such societies. Each Adhering Body shall form a National Committee for Crystallography to represent it in the Union.

3.4. Any number of Countries may agree to form a group in order to name or establish a single Adhering Body. This Body shall form a joint National or Regional Committee for Crystallography. Wherever the terms Country and National Committee for Crystallography are used in these Statutes or in the By-Laws, they shall be taken to include such groups of Countries and joint National or Regional Committees for Crystallography.

3-5. Membership in the Union shall be fully effective when the nature of the Adhering Body and the membership of the National Committee have been reported to and accepted by the General Assembly. Any replacement of an Adhering Body is subject to the approval of the Executive Committee and acceptance by the General Assembly. Any major change in the nature of an Adhering Body shall be considered valid only after it has been reported to and accepted by the General Assembly.

3.6. Adherence to the Union shall be in one of five Categories $\mathrm{I}-\mathrm{V}$ with corresponding voting powers and contributions as set out in Statutes 5.5 and 9.4. A Body applying for adherence to the Union shall specify in which Category it wishes to adhere; this choice of Category, or any desired change in the Category, is subject to the approval of the Executive Committee and confirmation by the General Assembly.

3.7. Any extension of a joint adherence formed in accordance with Statute 3.4 is subject to the approval of the Executive Committee and acceptance by the General Assembly.

3.8. Participation in Special Projects [Statute $1 \cdot 2(f)$ ] shall not be obligatory. The extent of financial participation shall be a matter for special negotiation for each such project, except that the relationship between contribution and voting power within the project shall be that of the Category scheme defined in Statutes 5.5 and 9.4 to determine this relationship in the General Assembly. 
3.9. Each National Committee has the right to submit to the Union through the General Secretary questions within the competence of the Union.

3.10. Any Adhering Body may withdraw from the Union if it has given notice of withdrawal at least six months before the end of the current financial year; it is required to fulfil its obligations relating to the time period when it was a member of the Union. Its membership and any further obligations shall then be suspended by the Executive Committee at the expiry of the notice of withdrawal. The withdrawal shall take effect when it has been reported to the General Assembly.

3.11. An Adhering Body which withdraws from the Union in accordance with Statute $3 \cdot 10$, or any Adhering Body whose membership is cancelled in accordance with Statutes 5.12 or $9 \cdot 6$, loses all rights in connexion with the Union.

3.12. If the Countries of a group formed in accordance with Statute 3.4 agree that the group should be dissolved, or if a Country wishes to withdraw from such a group, with or without the agreement of the other Country or Countries of the group, the adherence of the original group shall be suspended by the Executive Committee at the expiry of an appropriate notice, provided that the original group has fulfilled its obligations. The termination of the original adherence shall take effect when the matter has been reported to the General Assembly. Pending this report, the Countries of the group, or any of them, may submit proposals for the continuation of their representation in the Union. In each of such proposals the nature of the Adhering Body, the membership of the National Committee and the desired Category of adherence shall be specified. These proposals are subject to the approval of the Executive Committee, which shall then make ad interim arrangements concerning these adherences. These arrangements are subject to acceptance by the General Assembly.

\section{Administration}

$4 \cdot 1$. The work of the Union shall be conducted by

(a) the General Assembly;

(b) the Officers of the Union, constituting the Executive Committee;

(c) the Commissions as defined in Statute 8.1.

The composition and function of these bodies are defined in the following paragraphs, whose application is governed by the By-Laws.

\section{General Assembly}

5.1. The work of the Union shall be directed by the General Assembly which is composed of delegates appointed by the Adhering Bodies.

5.2. The Executive Committee is responsible to the General Assembly and shall participate in its deliberations. Members of the Executive Committee have no voting power in the General Assembly, except for the casting vote of the Chairman [Statute 5.8].

5.3. The General Assembly shall, as a rule, hold an ordinary meeting once every three years. The date and the place of the meeting, unless determined by the previous General Assembly, shall be determined by the Executive Committee. The General Secretary shall communicate the date and the place of the meeting to the National Committees and to the Commissions at least twelve months in advance.
5.4. In special cases, the President of the Union, with the consent of the Executive Committee, may call an extraordinary meeting of the General Assembly. He shall do so at the request of one-fifth of the Adhering Bodies. The routine business of a General Assembly prescribed in Statute 5.10 shall normally be omitted, unless specifically included in the agenda; but an extraordinary General Assembly shall have the same powers, and be subject to the same rules, as an ordinary General Assembly, except where otherwise is stated in the Statutes and By-Laws. The General Secretary shall communicate the date and the place of the extraordinary General Assembly to the National Committees and to the Commissions at least eight months in advance if amendment of the Statutes is contemplated, or at least four months otherwise.

5.5. The voting power of an Adhering Body at General Assemblies shall be in accordance with its Category of adherence, as follows

$\begin{array}{lccccc}\text { Category } & \text { I } & \text { II } & \text { III } & \text { IV } & \text { V } \\ \text { Number of votes } & 1 & 2 & 3 & 4 & 5\end{array}$

5.6. Each Adhering Body, through its National Committee, shall make known to the General Secretary before the opening of each General Assembly the names of its delegates (and of their alternates, if any), and also the name of the chairman of the national or regional delegation. No Officer of the Union may be a member of any delegation, nor shall any person serve as a member of more than one delegation.

5.7. Normally each of the delegates present at a General Assembly shall have one vote only, but when for special reasons an Adhering Body cannot be fully represented at a General Assembly it may distribute its votes among a number of delegates smaller than the number of yotes which that Adhering Body has in accordance with the Category in which it adheres; such a decision has to be made known to the General Secretary before the opening of the General Assembly concerned. Any Adhering Body not represented at a General Assembly may forward its views to the General Secretary by letter, and such views shall be made known to the General Assembly if received before voting takes place.

5.8. Except where otherwise provided in the Statutes and By-Laws, decisions of the General Assembly are taken by a majority of the votes cast. In the event of an equal division of votes the Chairman shall take the final decision.

5.9. No question which has not been placed on the agenda of business to be transacted at the General Assembly shall be discussed or put to the vote unless a proposal to that effect be approved by at least two-thirds of the votes there represented.

5.10. The General Assembly shall

(a) take appropriate action on any matters concerning membership in the Union [Statues 3.5, 3.6, 3.7, 3.10, $3 \cdot 12$ and $5 \cdot 121$;

(b) elect the President, the Vice-President, the General Secretary, the Treasurer and the other Officers of the Union [Statutes 6.1 and 6.3];

(c) consider, and make decisions regarding, the confirmation of the appointments of Editors of publications of the Union [Statute 7.1];

(d) determine the number of elected members of each Commission set up by the General Assembly [Statutes $5 \cdot 11(c)$ and $8 \cdot 2]$; 
(e) elect the Chairmen and members of the Commissions [Statute $8 \cdot 2$ ];

$(f)$ elect representatives of the Union on Joint Commissions with other Unions, and on other scientific bodies [Statutes $1 \cdot 2(g)$ and $8 \cdot 5$ ];

(g) receive the reports on the activities of the Union and of its Commissions [Statutes 6.8 and 8.4 ];

(h) receive the audited accounts for the years elapsed since the previous General Assembly [Statute $9 \cdot 1$ ];

(i) on receipt of satisfactory reports or accounts, release the Treasurer, or any other Officer, or the Chairman or any member of any Commission or other body, from financial or other liability to the Union;

(j) determine the budget for general expenditure for the period to the next General Assembly, on the basis of the estimate prepared by the Executive Committee [Statutes $9 \cdot 2$ and $9 \cdot 3$ ];

(k) determine the unit contribution for the period to the next General Assembly [Statute 9.5]:

(l) determine the general policy and the timetable for the period to the next General Assembly;

(m) give preliminary consideration to the activities of the Union for the three-year period following the next General Assembly.

5.11. The General Assembly shall have the power

(a) to amend these Statutes in accordance with Statute $13 \cdot 1$

(b) to formulate and amend By-Laws on any matters not covered by these Statutes;

(c) to set up any Commission or other body it may deem necessary for the administrative and scientific work of the Union, and to determine the terms of reference of such body $[$ Statute $1 \cdot 2(d)]$;

(d) to dissolve any Commission or other body set up in accordance with Statute $5 \cdot 11(\mathrm{c})$ when its existence is deemed no longer necessary;

(e) to determine the nature of Special Projects which shall be financed independently of the regular operations of the Union [Statute 1-2(f)];

$(f)$ to accept Regional Associates, to determine the nature of the association in each case, and to determine any mutual financial commitments;

(g) to accept Scientific Associates, to determine the nature of the association in each case, and to determine any mutual financial cornmitments;

(h) to decide on all other questions falling within the competence of the Union.

5.12. The General Assembly may cancel the membership of any Adhering Body of the Union for any serious cause: such a decision may only be taken after the member in question has been previously given an opportunity to furnish an explanation to the Executive Committee for forwarding to the General Assembly. At least three-fourths of the total number of the votes of all Adhering Bodies are required for cancellation.

\section{Executive Committee}

6.1. The officers of the Union constituting the Executive Committee are

(a) the President;

(b) the Vice-President;

(c) the General Secretary;

(d) the Treasurer; (e) the immediate Past President;

$(f)$ six ordinary members.

6.2. The election of Officers of the Union shall be arranged in such a way that there will not be more than two Officers from any one Country. A person is regarded as belonging to the Country in which he is normally resident and where he conducts the main part of his work. In cases of doubt the General Assembly shall decide to which Country a person is considered to belong.

If during the period between General Assemblies the number of Officers from a Country is increased above two because of any change of Country of residence, the Officer or Officers who changed his or their Country of residence may continue his or their service until the close of the next General Assembly. If at that time the number of Officers from the Country concerned would remain above two, one or more of the Officers who changed his or their Country of residence shall be considered to have resigned.

6.3. The offices of General Secretary and Treasurer may be combined and shall then be considered as a single office. Otherwise no person shall hold more than one office simultaneously. The voting power of the Officer holding the combined office of General Secretary and Treasurer shall not be more than that of either the General Secretary or the Treasurer.

6.4. The President holds office as President until the close of the ordinary General Assembly following his election, and continues as a member of the Executive Committee until the close of the ordinary General Assembly next but one following that of his election. He is not then eligible for immediate re-election to the office of President, nor to any other office in the Executive Committee.

The Vice-President holds office until the close of the ordinary General Assembly following his election. He is not eligible for immediate re-election to the same office.

The General Secretary and the Treasurer hold office until the close of the ordinary General Assembly following that of their election. They are eligible for immediate re-election to the same office, but shall not serve in that office for more than three full consecutive terms.

Three ordinary members are elected at each ordinary General Assembly and hold office until the close of the ordinary General Assembly next but one following that of their election. They are not eligible for immediate re-election to the same office.

In the event of a vacancy, through resignation, death or other cause, any Officer elected by the General Assembly to fill the unexpired term of office shall serve only to the end of the normal term of the Officer he replaces; at the end of this service he may be nominated for re-election for a full term to the same office.

6.5. The Executive Committee shall carry out the decisions of the General Assembly and give effect to the general policy of the Union as determined by the General Assembly.

6.6. During the periods between General Assemblies the Executive Committee shall have full power to carry on the business of the Union in all matters not specifically assigned by the Statutes, the By-Laws or the General Assembly to individuals or to Commissions or other bodies. If necessary, it may make ad interim arrangements in all matters assigned by the Statutes and By-Laws to the General Assembly.

6.7. In the event of an individual, a Commission or another body of the Union failing to act in any matter as- 
signed to him or it by the Statutes, By-Laws or the General Assembly, the Executive Committee may, after reasonable notice to the individual or body in question, take action on behalf of the Union.

6.8. The Executive Committee shall report on its activities to the General Assembly. The action taken by the Executive Committee in accordance with Statutes 3.5, 3.6, $3 \cdot 7,3 \cdot 10,3 \cdot 12,6 \cdot 6,6 \cdot 7,7 \cdot 1,7 \cdot 2,8 \cdot 2,9 \cdot 6$ and $9 \cdot 9$ shall be included in this report. The report to the General Assembly shall be dispatched by the General Secretary to the National Committees and to the Commissions at least ten weeks before the meeting.

\section{Publications of the Union}

7.1. The Editors of the publications of the Union are appointed by the Executive Committee for initial terms extending through not more than six years beyond the ordinary General Assembly following the appointment. Each initial appointment is subject to confirmation by that General Assembly. Reappointments may be made by the Executive Committee for terms of not more than three years, and are subject to confirmation by the ordinary General Assembly following the reappointment.

7.2. Co-editors and Assistant Editors are appointed by the Editors for terms of not more than three years, but they may be reappointed immediately for terms of the same length. The appointments and reappointments are subject to the approval of the Executive Committee.

7.3. Editors and Co-editors are members of the Com missions set up for their respective publications.

\section{Commissions and Joint Commissions}

8.1. The term 'Commission' shall be understood to include all Commissions, Committees, and other bodies of the Union with the exception of National Committees for Crystallography, and the Executive Committee and its subcommittees.

8.2. The Chairmen and members of the Commissions are elected at each General Assembly. Subject to the approval of the Executive Committee, Commissions may co-opt further members during the periods between General Assemblies, and may fill vacancies arising from resignation, death or other cause. Members (but not Chairmen) may be nationals of or residents in a Country not adhering to the Union.

8.3. The Commissions shall be responsible to the General Assembly. They shall generally have full freedom in arranging their internal structure and work. They may formulate their own Rules of Procedure within the framework of the Statutes and By-Laws of the Union, and within their terms of reference.

8.4. The Chairmen shall report on the activities of the Commissions to the General Assembly. These reports shall reach the General Secretary at least fourteen weeks before the General Assembly and shall be dispatched by him to the National Committees and the Commissions at least ten weeks before the meeting.

8.5. The representatives of the Union on Joint Commissions and on other scientific bodies [Statute $1 \cdot 2(\mathrm{~g})$ ] are elected at each General Assembly. For each such body one representative shall be designated as the chief representative of the Union. His obligations to report are the same as those of the Chairmen of the Commissions.

\section{Finance}

9.1. The Executive Committee shall be responsible to the General Assembly for all the financial affairs of the Union.

9.2. The Chairman of each Commission (or other member approved by the Executive Committee) shall be responsible to the Executive Committee for any expenditure of funds by his Commission. Five months before each General Assembly he shall submit to the Executive Committee an estimate of the budget of his Commission for the period between that General Assembly and the one following it. He shall submit annually to the Executive Committee a revised budget for the ensuing year and a statement of accounts for the preceding year. His accounts shall be available for audit by the Executive Committee or its appointees.

9.3. The Executive Committee shall prepare an estimate of the budget for the period between the next General Assembly and that following it. This estimate shall be dispatched by the General Secretary to the National Committees and to the Commissions at least ten weeks before the meeting.

9.4. Each Adhering Body shall pay an annual subscription in accordance with its Category of adherence, as follows

$\begin{array}{lccccc}\text { Category } & \text { I } & \text { II } & \text { III } & \text { IV } & \text { V } \\ \text { Number of unit contributions } & 1 & 3 & 6 & 10 & 15\end{array}$

The annual subscriptions are payable during the calendar year to which they apply.

9.5. The unit contribution, stated in terms of a currency to be designated by the Executive Committee, shall be determined by the General Assembly for the period to the next General Assembly.

9.6. Any Adhering Body which is in arrears with its subscription for two years shall be warned and shall be deprived of its voting power. The membership of any Adhering Body which is in arrears for four years shall be automatically suspended and may be cancelled by the General Assembly under Statute 5.12. An Adhering Body whose membership has been suspended shall receive no privileges of the Union and incur no further responsibility for dues; it may be reinstated by action of the Executive Committee.

9.7. The financing and management of publications of the Union shall be kept distinct from general expenditure. Editors and Co-editors shall be responsible to the Executive Committee for any receipts or expenditure of funds by them with respect to their publications.

9.8. The financing and management of Special Projects of the Union shall be kept distinct from the regular operations of the Union.

9.9. No funds may be solicited or accepted on behalf of the Union or any of its Commissions from any international, governmental or other agency or person without the prior approval of the Executive Committee. Any National Committee for Crystallography may however solicit funds within its own Country for the support of its own activities or in its capacity as host for a General Assembly, Congress or other meeting sponsored by the Union. Any funds in the form of donations, legacies, or grants, accepted by the Executive Committee shall be used so far as is possible in accordance with the wishes of the donors. 


\section{Liability}

10.1. The Union is liable only to the extent of its assets, and the Adhering Bodies are not individually liable for its corporate debts and liabilities.

10.2. The liabilities of the Adhering Bodies are limited to the payment of their annual subscriptions and to such contributions to the Special Projects of the Union as they may have pledged.

10.3. No Officer of the Union shall be individually liable for the corporate debts and liabilities of the Union. The Union shall indemnify any Officer or former Officer in respect of any claims laid against him in respect to his authorized actions on behalf of the Union. At its discretion the Executive Committee may extend this indemnity to other persons in respect of their authorized actions on behalf of the Union.

10.4. The Union shall not accept any liability for any personal loss, damage or accident sustained by an individual, not being an employee of the Union, engaged in any activity, including travel, on behalf of the Union.

\section{Auditor and Representation of the Union}

11.1. The Auditor of the Union shall be a person or corporation authorized to act as a public accountant. The Auditor shall be appointed by the Executive Committee on the recommendation of the Treasurer and maintained thereafter subject to the approval of the General Assembly.

11.2. With the exception of cheques, all contracts and formal agreements involving the Union shall be signed by two Officers of the Union. The Executive Committee may restrict the power to sign a particular document or type of document to specific persons among the Officers; and it shall determine rules for the signing of cheques.

11.3. The President shall be the official representative of the Union on all other civil and legal occasions and in dealing with other organizations. He may in this respect delegate his powers to another Officer of the Union, or, with approval of the Executive Committee, to any other person.

\section{Dissolution of the Union}

12.1. The Union shall not be dissolved except on a motion presented at a General Assembly. If a motion to dissolve is to be presented, the notice for that General Assembly as given under Statute 5.3 or 5.4 shall include a statement of the motion to dissolve and shall refer specifi- cally to this Statute. Such a motion shall be presented to the General Assembly without amendment and at least threefourths of the votes there represented shall be required for dissolution.

In the event that less than three-fourths of the total number of the votes of all Adhering Bodies are represented at the General Assembly, a postal ballot may be arranged, and in such a postal ballot at least three-fourths of the total number of the votes of all Adhering Bodies shall be required for dissolution.

12.2. In the event of dissolution of the Union in accordance with Statute $12 \cdot 1$, the General Assembly shall appoint a special Committee, reporting to the International Council of Scientific Unions, for the liquidation of the assets of the Union. The nett assets shall be given to one or more, preferably international, organizations or institutions which shall spend the assets for purposes so far as is possible in accordance with the objects of the Union.

\section{Statutes}

13.1. Amendments to the Statutes require action at a General Assembly. An amendment is adopted at such an Assembly only if (i) at least two-thirds of the votes represented at the General Assembly are affirmative and (ii) if these affirmative votes amount to more than half the total number of the votes of all Adhering Bodies. In the event that the vote on a proposed amendment satisfies condition (i) but not condition (ii), the Executive Committee may refer the proposed amendment to a postal ballot of the Adhering Bodies. If the proposed amendment then obtains affirmative votes amounting to more than half the total number of the votes of all Adhering Bodies, the amendment is adopted.

Proposals for amendments may be made by the Executive Committee or by any National Committee. Such proposals made by National Committees shall reach the General Secretary at least six months in advance of the General Assembly. The General Secretary shall dispatch these proposals, and those made by the Executive Committee, to the National Committees and to the Commissions at least four months before the meeting.

13.2. The present English text shall be considered the authoritative text in the interpretation of these Statutes. Where disputes arise concerning this interpretation, the matter shall be decided by the General Assembly, or, during the periods between General Assemblies, by a ruling of the President of the Union.

\section{By-Laws}

\section{General Assembly}

1.1. The agenda of business to be transacted at a General Assembly shall be determined by the Executive Committee and shall be dispatched by the General Secretary to the National Committees and to the Commissions at least ten weeks before the meeting.

1.2. Any National Committee and any Commission of the Union may propose business to be transacted at a General Assembly. Such proposals shall reach the General Secretary at least four months before the meeting, and shall be included in the agenda of the General Assembly.
1.3. The General Assembly may provisionally determine the date and the place of the next but one ordinary meeting of the General Assembly.

1.4. Chairmen of the National Committees and of the Commissions, and representatives of Regional Associates and Scientific Associates may attend the General Assembly and take part in the discussions but shall have no voting power. The President may invite representatives of scientific bodies, or individuals, to attend the General Assembly; such invited guests may take part in the discussions but shall have no voting power. Other interested persons may also attend the General Assembly but they shall not take part in the dis- 
cussions, unless specifically invited or permitted to do so by the Chairman, and they shall have no voting power.

At the discretion of the Chairman any or all of the persons attending the General Assembly under this By-Law may be required to withdraw.

1.5. If a delegate to a General Assembly is absent from a session of the Assembly, his place may be taken by any of the alternates nominated to the Assembly under Statute 5.6 provided that the Secretary of the Assembly is notified before the beginning of the session of the name of the delegate and of the name of the alternate, either by the delegate or by the chairman of his delegation. In general no such substitution may take place during a session of the Assembly, but the Chairman of the Assembly may permit substitution to be made under special circumstances.

1.6. The names of the representatives of a Body whose application for adherence to the Union has been received and declared in good order by the Executive Committee under By-Law 2.9(a), shall be made known to the General Secretary as prescribed in Statute $5 \cdot 6$. These representatives shail be seated with the delegates of the Adhering Bodies during the preliminary ceremonies and the initial business of the General Assembly. At the discretion of the Chairman or by a vote of the Assembly, the representatives may be required to withdraw during the discussion of and voting on matters concerning adherence to the Union. The delegates of a new member may take their seats among the other delegates as soon as the General Assembly has accepted their Adhering Body as a member of the Union.

1.7. Unless decided otherwise by the General Assembly, matters concerning adherence to the Union shall take precedence over all other business at the first business session of the General Assembly, and shall normally precede the reading of the minutes and the discussions of matters arising therefrom.

1.8. Delegates of an Adhering Body may not vote on any matter concerning its membership in the Union.

1.9. In the event of the General Assembly considering a change in a group of Countries according to Statute $3 \cdot 12$, the delegates from the Countries belonging or previously belonging to the group may not vote on any matters concerning the representation in the Union of any of these Countries. After acceptance of the ad interim arrangements made by the Executive Committee under Statute $3 \cdot 12$, these delegates have full voting power.

$1 \cdot 10$. The delegates of new members may not vote on any matters concerning adherence to the Union, nor on any matters concerning the adoption of the minutes of the previous General Assembly, during the General Assembly at which they themselves are admitted.

1.11. The General Secretary shall post on the official bulletin board of the General Assembly the names of the Chairmen and members (and alternates, if any) of the delegations and the numbers of votes represented by them.

1.12. During the General Assembly any delegate (or alternate) and any Officer of the Union is considered to have been notified of any action of the General Assembly, or of the Executive Committee, or of any Commission, if one of the two following procedures is adopted

(a) a notice is placed in the mail box or other location at which the delegate (or alternate) or the Officer is accustomed to receive his mail during the course of the General Assembly, or (b) a notice is handed to the designated Chairman of each delegation with the specific request that he communicate its contents to his delegation, and to the General Secretary with the specific request that he communicate its contents to the Executive Committee,

provided that in either case a similar notice is posted on the official bulletin board.

1.13. Minutes of the meetings of the General Assembly shall be made. Copies of the draft minutes shall be communicated by the General Secretary to the National Committees, to the Officers of the Union and to the Chairmen of its Commissions. After approval at a subsequent General Assembly, two copies of the definitive minutes shall be signed by the Chairman and the Secretary of the session at which they are approved, and shall be kept by the President and the General Secretary.

\section{Executive Committee}

2.1. The Executive Committee shall meet at each General Assembly. There shall be at least two additional meetings during the period between General Assemblies, unless the Executive Committee by a postal vote decides otherwise.

2.2. The Executive Committee shall make nominations to the General Assembly for the Officers of the Union, for the Chairmen and members of the Commissions, and for representatives on Joint Commissions and on other scientific bodies. Normally these nominations shall be made after a preceding postal communication with the National Committees. In each case in which an Officer of the Union is nominated for another office, either by the Executive Committee or by delegates to the General Assembly [ByLaw 7.2], the Executive Committee shall also include a nomination for the office which would be vacated if the election to the other office occurs. If the election to the other office does not occur and if the Officer's term has not expired, the nomination to the office which would have been vacated shall not be considered.

$2 \cdot 3$. In the event of the resignation, death or disability of the President, the Vice-President shall assume the office of President until the close of the next ordinary General Assembly.

In the event of the resignation, death or disability of the Vice-President, the Executive Committee may appoint one of its members to serve as Vice-President until the close of the next ordinary General Assembly.

In the event of such circumstances that the General Secretary or the Treasurer cannot carry out his duties, the other shall assume those duties until the Executive Committee has considered the situation. In that event the Executive Committee may, but need not, appoint a new General Secretary or Treasurer to serve until the close of the next ordinary General Assembly.

In the event of the resignation, death or disability of an ordinary member of the Executive Committee, the Executive Committee may co-opt a new member to serve until the close of the next ordinary General Assembly.

The accession of an Officer of the Union to a new office under the conditions of this By-Law shall be accompanied by his resignation from the office to which he was previously elected, but service under this By-Law shall not affect his eligibility for immediate re-election to the new office. 
2.4. Any Officer unable to attend a meeting of the Executive Committee may designate a deputy to attend that meeting. Such a deputy shall be named in writing to the President or the General Secretary. He shall have no voting power and shall not be counted as part of a quorum.

2.5 . The President, on his own initiative or at the request of the Executive Committee, may invite any individual to be present at a meeting of the Executive Committee; such an invited guest may take part in the discussions but shall have no voting power.

2.6. At a meeting of the Executive Committee two-thirds (fractional parts neglected) of the Officers specified by Statutes 6.1 and 6.3 , excluding any who have resigned or died, shall constitute a quorum; and decisions shall be taken by a simple majority of the Officers present and voting. The Chairman of the meeting shall not vote in open ballots; but in the event of an equal division of votes the Chairman may take the final decision. In secret ballots required by the Statutes or By-Laws or ordered by the Chairman he may vote at his discretion. If he does not vote and there is an equal division of votes he may take the final decision. If he has voted in a secret ballot he may not take the final decision, and must leave it to further discussion and ballot.

2.7. During the period between meetings of the Executive Committee, voting may take place by post. Adoption of a proposal shall require affirmative votes from two-thirds (fractional parts neglected) of the Officers specified by Statutes 6.1 and 6.3 , excluding any who have resigned or died. No decision on any proposal other than calling or cancelling a meeting of the Executive Committee shall be made by postal vote in the event that at least two Officers express the wish that the matter concerned should first be given more or further consideration, either by correspondence or at a meeting of the Executive Committee.

2.8. Minutes of the meetings of the Executive Committee shall be made. Two copies of the minutes shall be signed by the Chairman and the Secretary of the meeting at which they are approved, and shall be kept by the President and the General Secretary. A summary of the draft minutes of meetings of the Executive Committee shall be despatched by the General Secretary to the National Committees within ten weeks of the conclusion of each meeting.

2.9. In addition to the obligations described in the Statutes and elsewhere in these By-Laws, the Executive Committee shall

(a) receive and report on applications for adherence to the Union if the nature of the applying Body and the membership of the National Committee have been duly reported to and considered to be in good order by the Executive Committee; pending the next General Assembly the Executive Committee may in the case of such applications provide such services of the Union as it deems proper;

(b) consider and report on any other questions concerning adherence to the Union;

(c) present an annual report, including an audited statement of receipts and expenditure, to the National Committees;

(d) report to the Commercial Registry of Geneva any changes in the registered information concerning the Union:

(e) have the power to appoint representatives on scientific bodies not belonging to the Union.

\section{President}

3. 1. The President of the Union is Chairman of the General Assembly and of the Executive Committee. In the absence of the President from a session or meeting, the VicePresident, or if he is not present another Officer of the Union designated by the Executive Committee, shall act as Chairman.

3.2. The President of the Union is an ex officio member, with voting power, of all Commissions of the Union.

\section{General Secretary}

4.1. The General Secretary of the Union is Secretary of the General Assembly and of the Executive Committee. In his absence from a session or meeting, another Officer of the Union designated by the Executive Committee shall act as Secretary.

4.2. The General Secretary of the Union is an ex officio member, with voting power, of all Commissions of the Union.

4.3. The General Secretary is responsible for conducting the ordinary business of the Union, with the exception of the financial administration, and for keeping its records.

\section{Treasurer}

5.1. The Treasurer of the Union is responsible for the financial administration of the Union and for keeping its accounts.

5.2. The Treasurer is an ex officio member of all Commissions of the Union, with voting power only for those questions which may involve the Union in financial commitments.

\section{Commissions of the Union}

6.1. The Chairmen of the Commissions and the chief representatives on Joint Commissions or other bodies shall forward records of all meetings of the Commissions to the President and the General Secretary. They shall report annually on the activities of these bodies to the Executive Committee.

6.2. If funds are provided for the use of a Commission, it may make its own financial arrangements, with the prior approval of the Executive Committee and subject to the provisions of the Statutes and By-Laws. In cases where the Executive Committee has given prior approval, payments toward travelling expenses of Chairmen and members of Commissions may be made from the general funds of the Union.

6-3. No person who has served for three consecutive full terms of office on a Commission is eligible for nomination for a fourth consecutive term of service on the same Commission except as Chairman. In no case is any person eligible for more than four consecutive full terms of service on the same Commission. These limitations do not apply to Editors [Statute 7.1I, Co-editors [Statute 7.2] and ex officio members. Any Commission, in its Rules of Procedure, may reduce the length of service specified here.

6.4. In the event of the resignation, death or disability of the Chairman of any Commission, the Executive Committee shall appoint a member of that Commission to serve as Chairman until the close of the General Assembly following this appointment. 


\section{Nominations and Elections}

7.1. All delegates (and aiternates) shall be notified of the nominations presented by the Executive Committee under By-Law 2.2 for the Officers of the Union as early as possible and at least ninety-six hours before the scheduled commencement of the session of the General Assembly at which the vote is to be taken.

7.2. After the delegates have been notified of the nominations by the Executive Committee as prescribed in By-Law $7 \cdot 1$, other nominations for Officers of the Union may be made by any six or more delegates. Such nominations shall be made in writing to the General Secretary not less than thirty-six hours before the voting session and shall be accompanied by a written statement that the consent of the nominees has been obtained. These nominations shall be posted by the General Secretary on the official bulletin board not less than twenty-four hours before that session.

7.3. Recommendations from each Commission for the Chairman and members of the Commission shall be made in writing to the General Secretary not less than seventy-two hours before the voting session of the General Assembly. These recommendations shall be approved by a majority of the members of the Commission and shall be accompanied by a written statement that the consent of the persons recommended has been obtained. All delegates (and alternates) shall be notified of the nominations presented by the Executive Committee under By-Law 2.2 for the Chairman and members of each Commission at least forty-eight hours before the voting session.

7.4. After the delegates have been notified of the nominations by the Executive Committee as prescribed in By-Law $7 \cdot 3$, other nominations for the Chairman and members of each Commission may be made by any six or more delegates. Such nominations shall be made in writing to the General Secretary not less than twenty-four hours before the voting session and shall be accompanied by a written statement that the consent of the nominees has been obtained. These nominations shall be posted by the General Secretary on the official bulletin board not less than twelve hours before that session.

7.5. In voting for the President, Vice-President, General Secretary and Treasurer of the Union, each of these offices shall be taken separately and voting shall be by secret ballot. A simple majority of the votes represented by the delegates present at the voting session shall be required for election. If there is only one candidate for one of these offices, his nomination shall be presented to the General Assembly and the candidate concerned shall be considered as elected. If there are two candidates or more, and an election is not achieved after two ballots, the candidate receiving the smallest number of votes in the second ballot shall be removed from the list. If an election is not achieved after a third ballot, this procedure shall be repeated until an election is achieved. Any ballot form showing more than one mark shall be invalid. Any contingency arising during the balloting shall be resolved by a ruling of the Chairman of the General Assembly.

7.6. The election of the ordinary members of the Executive Committee shall be by secret ballot, the ballot form showing the nominations presented by the Executive Committee and the nominations made by delegates. A simple majority of the votes represented by delegates present at the voting session shall be required for election. If there are not more candidates than vacancies, the nominations shall be presented to the General Assembly and the candidates shall be considered as elected. If there are more candidates than vacancies and all vacancies are not filled by election at the first ballot, a second ballot shall be arranged containing the names of the candidates not elected. If there are vacancies after the second ballot, the balloting procedure shall be repeated until all vacancies are filled; for each of these subsequent ballots the name of the candidate receiving the smallest number of votes on the preceding ballot shall be removed from the list. Any ballot form showing more marks than the appropriate number of vacancies shall be invalid. Any contingency arising during the balloting shall be resolved by a ruling of the Chairman of the General Assembly.

7.7. In the event that an election must be held to fill the unexpired term of an office vacated by an ordinary member [Statute 6.4], the nominations for this office shall be distinct from the nominations for ordinary members for full terms. A person may be nominated for both categories, but can be elected to only one office [Statute $6 \cdot 3$ ]. If ballots are required in the elections for both categories, the ballots for the fullterm offices shall take place first. A person who has been elected to two consecutive non-full terms is not eligible, on completion of his second term, for immediate re-election as an ordinary member of the Executive Committee.

7.8. In voting for the Chairmen and members of the Commissions each Commission shall be considered separately. For the election of the Chairmen the procedure described in By-Law 7.5 shall be followed. For the election of the members of the Commissions the procedure described in By-Law 7.6 shall be followed except that no more than two ballots shall be held. Any vacancies still remaining may be filled as provided in Statute $8 \cdot 2$.

7.9. The procedure for the nomination and election of representatives of the Union on Joint Commissions and on other scientific bodies is so far as is possible the same as that for the nomination and election of the Chairmen and members of the Commissions.

\section{By-Laws}

8.1. These By-Laws may be amended or suspended at any General Assembly and at least two-thirds of the votes there represented are required for an amendment or suspension. A motion to amend or suspend, if not already included in the agenda of business of the General Assembly, may be placed there by the procedure of Statute 5.9. No notice is required for a proposal to suspend the time limits prescribed by By-Laws 7.2 and 7.4. Notification of any other motion to amend or suspend the By-Laws must be given by its originators to all delegates (and alternates) and to all Officers of the Union in accordance with the procedure prescribed in By-Law 1.12, at least forty-eight hours before the session of the General Assembly at which the motion is to be considered.

8-2. Words importing the male sex in the Statutes and ByLaws shall include the female sex.

8.3. The present English text shall be considered the authoritative text in the interpretation of these By-Laws. Where disputes arise concerning this interpretation, the matter shall be decided by the General Assembly, or during the periods between General Assemblies, by a ruling of the President of the Union. 


\section{APPENDIX}

Timetable in Preparation for General Assembly

12 months Notice of date and place of ordinary General Assembly to National Committees and Commissions

8 months Notice of date and place of extraordinary General Assembly to National Committees and Commissions, if amendment of Statutes is contemplated

6 months

Proposals for amendments to Statutes to General Secretary

5 months

4 months

Estimated budgets from Commissions to Executive Committee

Proposals for agenda of General Assembly to General Secretary

4 months

Notice of date and place of extraordinary General Assembly to National Committees and Commissions, if amendment of Statutes is not contemplated

4 months

14 weeks

10 weeks

10 weeks

10 weeks

10 weeks

Proposals for amendments to Statutes to National Committees and Commissions

Reports of Commissions to General Secretary

Report of Executive Committee to National Committees and Commissions

Reports of Commissions to National Committees and Commissions

Budget to National Committees and Commissions

Agenda to National Committees and Commissions

Statute By-Law

\section{Timetable during General Assembly}

'Before'

96 hours

72 hours

48 hours

48 hours

36 hours

24 hours

24 hours

12 hours
Notice by National Committees to General Secretary of names of delegates, alternates and chairmen of delegations, and of distribution of votes if not one per delegate

Nominations by Executive Committee for Officers of Union

Recommendations by Commissions to General Secretary for Chairmen and members of Commissions

Nominations by Executive Committee for Chairmen and members of Commissions

Notification of motion to amend or suspend By-Laws

Notice to General Secretary of nominations by delegates for Officers of Union

Posting of nominations by delegates for Officers of Union

Notice to General Secretary of nominations by delegates for Chairmen and members of Commissions

Posting of nominations by delegates for Chairmen and members of Commissions

\section{$5 \cdot 3$}

$5 \cdot 4$

$13 \cdot 1$

9.2

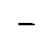

$5 \cdot 4$

$13 \cdot 1$

8.4

$6 \cdot 8$

8.4

$9 \cdot 3$

$-$

$\begin{array}{cc}5.6,5.7 & - \\ - & 7.1 \\ - & 7.3 \\ - & 7.3 \\ - & 8.1 \\ - & 7.2 \\ - & 7.2 \\ - & 7.4 \\ - & 7.4\end{array}$




\title{
ANNEX III \\ Committees, Commissions, Regional and Scientific Associates and Representatives on Other Bodies
}

\author{
Membership of Bodies belonging to the Union
}

\author{
EXECUTIVE COMMITTEE \\ President \\ J. Karle* \\ Code 6030 , Laboratory for the \\ Structure of Matter, Naval \\ Research Laboratory, \\ Washington DC 20375, USA
}

\section{Vice-President \\ S. Ramaseshan* (India) \\ General Secretary and Treasurer \\ K. V. J. Kurki-Suonio* Department of Physics, University of Helsinki, Siltavuorenpenger $20 \mathrm{D}$, SF-00170 Helsinki 17, Finland}

\section{Immediate Past President \\ N. Kato* (Japan)}

\section{Ordinary Members}

S. Amelinckx $\dagger$ (Belgium)

Th. Hahn $†$ (Federal Republic of Germany)

M. Nardelli† (Italy)

H. Neels* (German Democratic Republic)

V. I. Simonov* (USSR)

M. M. Woolfson* (UK)

\section{Executive Secretary}

\section{J. N. King}

International Union of Crystallography, 5 Abbey Square, Chester CH1 2HU, England

\section{COMMISSION ON JOURNALS}

\section{Chairman and Editor of Acta}

Crystallographica

S. C. Abrahams

Bell Laboratories, 600 Mountain Avenue, Murray Hill, New Jersey 07974, USA

* Until the close of the Thirteenth General Assembly (1984).

$\uparrow$ Until the close of the Fourteenth General Assembly (1987).
Co-Chairman and Editor of Journal of Applied Crystallography

M. Hart

Department of Physics, King's College, Strand, London WC2R 2LS, England

\section{Co-editors}

F. R. Ahmed (Canada; Acta)

R. Colella (USA; $A c t a$ )

T. A. Hamor (UK; Acta)

M. Hospital (France; $A c t a)$

G. A. Jeffrey (USA; $A c t a$ )

G. Kostorz (Switzerland; $J A C$ )

M. Nardelli (Italy; $A$ cta)

R. Norrestam (Denmark; $A c t a$ )

J. Protas (France; Acta)

S. E. Rasmussen (Denmark; $J A C$ ) (as from 1 January 1983)

Y. Saito (Japan; $A c t a$ )

M. Schlenker (France; $J A C$ )

H. H. Schulz (Federal Republic of Germany; Acta)

G. A. Sim (UK; $A c t a)$

V. I. Simonov (USSR; $A c t a$ )

D. H. Templeton (USA; $A c t a$ )

D. Watanabe (Japan; $J A C$ )

B. T. M. Willis (UK; $A c t a)$

H. L. Yakel (USA; $J A C$ )

\section{Book Review Editor}

J. H. Robertson (UK; Acta and $J A C$ )

COMMISSION ON STRUCTURE REPORTS Chairman and Editor

G. Ferguson

Department of Chemistry, University of Guelph, Ontario, Canada

\section{Co-editors}

L. D. Calvert (Canada)

J. Iball (UK)

S. N. Scrimgeour (UK)

C. B. Shoemaker (USA)

J. Trotter (Canada)

\section{Ex officio member}

I. D. Brown (Canada) (as Chairman of the Commission on Crystallographic Data)
COMMISSION ON INTERNATIONAL

TABLES

Chairman and Editor

\section{A. J. C. Wilson $\ddagger$}

Crystallograhic Data Centre, University Chemical Laboratory, Lensfield Road,

Cambridge CB2 1EW, England

Co-editor

U. Shmuelił (Israel)

COMMISSION ON BIOLOGICAL MACROMOLECULAR CRYSTALLOGRAPHY

Chairman

M. G. Rossmann

Department of Biological Sciences, Purdue University, West Lafayette, Indiana 47907, USA

\section{Elected members}

T. L. Blundell (UK)

C. I. Brändén (Sweden)

J. Drenth (Netherlands)

R. M. Haser (France)

W. A. Hendrickson (USA)

Dong-Cai Liang (People's Republic of China)

D. C. Phillips (UK)

B. K. Vainshtein (USSR)

COMMISSION ON CHARGE, SPIN AND MOMENTUM DENSITIES

Chairman

M. J. Cooper

Department of Physics,

University of Warwick,

Coventry CV4 7AL, England

Elected members

P. Becker (France)

S. Berko (USA)

R. A. Bonham (USA)

P. J. Brown (France)

F. Hirshfeld (Israel)

M. S. Lehmann (France)

$\ddagger$ Appointed in 1982 . 
Elected members (cont.)

F. Menzinger (Italy)

R. P. Ozerov (USSR)

Y. Saito (Japan)

J. R. Schneider (Federal Republic of Germany)

V. H. Smith (Canada)

Ex officio member

M. S. Lehmann (France) (as Chairman of the Commission on Neutron Diffraction)

COMMISSION ON CRYSTAL GROWTH AND CHARACTERIZATION OF MATERIALS

Chairman

E. Kaldis

Institut für Festkörperphysik. ETH-Honggerberg, 8093 Zurich, Switzerland

Elected members
A. Authier (France)
A. N. Christensen (Denmark)
H. C. Gatos (USA)
H. Komatsu (Japan)
P. Krishna (India) (Secretary)
A. R. Lang (UK)
H. Peibst (German Democratic Republic)

\section{Ex officio members}

M. Hart (UK) (as Editor of Journal of Applied Crystallogrpahy)

D. T. J. Hurle (UK) (as

Representative of the International Organization for Crystal Growth)

COMMISSION ON CRYSTALLOGRAPHIC APPARATUS

\section{Chairman}

S. Abrahamsson

Department of Structural

Chemistry, Faculty of Medicine, University of Göteborg, Medicinaregatan 9, POB, S-400 33 Goteborg 33, Sweden

\section{Elected members}

J. Cermák (Czechoslovakia)

D. C. Creagh (Australia)

H. Hope (USA)

V. G. Lyutzau (USSR)

S. Martinez-Carrera (Spain)

G. Materlik (Federal Republic of Germany)

M. Zocchi (Italy)
COMMISSION ON CRYSTALLOGRAPHIC

COMPUTING

Chairman

S. R. Hall

Crystallography Centre,

University of Western Australia, Nedlands 6009. Australia

\section{Elected members}

V. I. Andrianov (USSR)

T. Ashida (Japan)

R. Diamond (UK)

K. Huml (Czechoslovakia)

C. K. Johnson (USA)

H. Schenk (Netherlands)

K. Venkatesan (India)

\section{Ex officio member}

I. D. Brown (Canada) (as Chairman of the Commission on Crystallographic Data)

COMMISSION ON CRYSTALLOGRAPHIC DATA

Chairman

I. D. Brown Institute for Materials Research, McMaster University, Hamilton, Ontario. Canada L8S MI

Elected members

F. H. Allen (UK)

G. Bergerhoff (Federal Republic of Germany)

A. Durif (France)

K. Łukaszewicz (Poland)

A. D. Mighell (USA)

K. Osaki (Japan)

E. Parthe (Switzerland)

C. Rømming (Norway)

Ex officio members

S. C. Abrahams (USA) (as Chairman of the Commission on Journals)

G. Ferguson (Canada) (as Chairman of the Commission on Structure Reports)

S. R. Hall (Australia) (as Chairman of the Commission on Crystallographic Computing)

\section{COMMISSION ON CRYSTALLOGRAPHIC NOMENCLATURE}

\section{Chairman}

S. C. Abrahams

Bell Laboratories, 600 Mountain Avenue, Murray Hill, New Jersey 07974, USA
Members
A. J. C. Wilson (UK)
G. Ferguson (Canada)
M. Hart (UK)

COMMISSION ON CRYSTALLOGRAPHIC STUDIES AT CONTROLLED PRESSURES AND TEMPERATURES

\section{Chairman}

B. Buras

Physics Department,

Risø National Laboratory,

Postbox 49, DK-4000 Roskilde, Denmark

\section{Elected members}

H. lwasaki (Japan)

S. S. Kabalkina (USSR)

F. Lissalde (France)

G. J. Piermarini (USA)

C. T. Prewitt (USA)

H. H. Schulz (Federal Republic of Germany)

A. K. Singh (India)

J. P. Traverse (France)

\section{Ex officio members}

S. Abrahamsson (Sweden) (as Chairman of the Commission on Crystallographic Apparatus)

P. Goodman (Australia) (as Chairman of the Commission on Electron Diffraction)

M. S. Lehmann (France) (as Chairman of the Commission on Neutron Diffraction)

COMMISSION ON CRYSTALLOGRAPHIC TEACHING

\section{Chairman}

\section{P. Krishna}

Physics Department, Faculty of Science, Banaras Hindu University, Varanasi 221005 , India

\section{Elected members}

S. Caticha-Ellis (Brazil)

E. Hoehne (German Democratic Republic)

C. H. L. Kennard (Australia)

M. Laing (South Africa)

W. M. Meier (Switzerland)

G. Rigault de la Longrais (Italy)

H. Schenk (Netherlands) (Secretary)

M. P. Shaskol'skaya (USSR)

You-chi Tang (People's Republic of China) 


\author{
COMMISSION ON ELECTRON \\ DIFFRACTION \\ Chairman \\ P. Goodman \\ CSIRO Division of Chemical \\ Physics, PO Box 160, Clayton, \\ Victoria 3168, Australia
}

\section{Elected members}

S. Amelinckx (Belgium)

I. Hargittai (Hungary)

K. Hedberg (USA)

C. J. Humphreys (UK)
F. Jona (USA)

H. Oberhammer (Federal Republic of Germany)

J. Pendry (UK)

D. Watanabe (Japan)

B. B. Zvyagin (USSR)

COMMISSION ON NEUTRON

DIFFRACTION

\section{Chairman}

M. S. Lehmann Institut Laue-Langevin, BP 156, Centre de Tri, 38042 Grenoble CEDEX, France
Elected members

R. Chidambaram (India)

H. Dachs (Federal Republic of Germany)

G. Dolling (Canada)

T. Hicks (Australia)

G. H. Lander (USA)

M. H. Mueller (USA)

Yu. Z. Nozik (USSR)

B. T. M. Willis (UK)

W. B. Yelon (USA)

\section{Regional and Scientific Associates}

Regional Associate: EUROPEAN CRYSTALLOGRAPHIC COMMITTEE

Scientific Associate: INTERNATIONAL ORGANIZATION FOR CRYSTAL GROWTH

\section{Representatives on Bodies not belonging to the Union}

COMMISSION ON THE SOLID STATE OF THE INTERNATIONAL UNION OF PURE AND APPLIED PHYSICS

Representative

A. Línek (Czechoslovakia)

Fysikální ústav,

Ceskoslovenská Akademie Věd, Libeñ,

Na Slovance 2,

18040 Praha 8 ,

Czechoslovakia

CONFERENCE COMMITTEE OF THE EUROPEAN PHYSICAL SOCIETY

Representative

A. Linek (Czechoslovakia)

Fysikálni,

Ceskoslovenská Akademie Věd,

Liben̆,

Na Slovance 2,

18040 Praha 8 ,

Czechoslovakia

EUROPEAN CRYSTALLOGRAPHIC COMMITTEE

\section{Representative}

S. Ramaseshan

Director, Indian Institute of

Science, Bangalore-560012, India
INTERNATIONAL ORGANIZATION FOR CRYSTAL GROWTH

Representative

E. Kaldis

Institut für Festkörperphysik, ETH-Honggerberg, 8093 Zurich, Switzerland

\section{Alternate}

\section{A. Authier}

Laboratoire de Minéralogie et

Cristallographie,

Université Pierre et Marie Curie, 4 Place Jussieu, 75230 Paris, France

ICSU ABSTRACTING BOARD

Representative

A. J. C. Wilson

Crystallographic Data Centre, University Chemical Laboratory, Lensfield Road, Cambridge CB2 IEW, England

ICSU COMMITTEE ON DATA FOR SCIENCE AND TECHNOLOGY (CODATA) Representative

I. D. Brown (Canada) (ex officio as Chairman of the Commission on Crystallographic Data)
ICSU COMMITTEE ON SCIENCE AND TECHNOLOGY IN DEVELOPING COUNTRIES (COSTED)

Representative

A. Authier (France)

Laboratoire de Minéralogie et

Cristallographie,

Université Pierre et Marie Curie, 4 Place Jussieu, 75230 Paris, France

ICSU COMMITTEE ON SPACE RESEARCH (COSPAR)

Representative

E. Kaldis

Institut für Festkörperphysik, ETH-Honggerberg, 8093 Zurich, Switzerland

ICSU COMMITTEE ON THE TEACHING OF SCIENCE

Representative

P. Krishna (India) (ex officio as Chairman of the Commission on Crystallographic Teaching) ICSU SCIENTIFIC COMMITTEE ON PROBLEMS OF THE ENVIRONMENT (SCOPE)

Representative

P. Kierkegaard

Department of Structural Chemistry, Arrhenius Laboratory, University of Stockholm, Fack S-10405 Stockholm, Sweden 


\section{ANNEX IV \\ Adhering Bodies}

$\begin{array}{lcc}\begin{array}{l}\text { Country } \\ \text { Argentina }\end{array} & \begin{array}{c}\text { Category } \\ \text { I }\end{array} & \begin{array}{c}\text { Adhering Body } \\ \text { Consejo Nacional de Investiga- } \\ \text { ciones Cientificas y Técnicas }\end{array} \\ \text { Australia } & \text { III } & \begin{array}{c}\text { Australian Academy of Science } \\ \text { Austria }\end{array} \\ \text { I } & \begin{array}{c}\text { Österreichische Akademie der } \\ \text { Wissenschaften }\end{array}\end{array}$

Begium

II Académie Royale des Sciences, des Lettres et des Beaux-Arts de Belgique

Brazil

III Conselho Nacional de Desenvolvimento Cientifico e Tecnologico

Canada

III National Research Council

Chile

China, People's Republic of

Czechoslovakia

Denmark

Egypt, Arab

Republic of

Finland

France

I

National Committee for Crystallography

IV Academia Sinica

I Ceskoslovenská Akademie Vèd

I Royal Danish Academy of Sciences and Letters

I Academy of Scientific Research and Technology

I Suomen Tiedeakatemiain Valtuuskunta

IV Académie des Sciences (Institut de France) German Democratic
Republic II $\begin{gathered}\text { Vereinigung für Kristallographie } \\ \text { in der GGW der DDR }\end{gathered}$ Germany, Federal IV Arbeitsgemeinschaft Kristallo-
Republic of

Hungary

I Magyar Tudományos Akadémia

India

I Indian National Science Academy

Israel

I Israel Academy of Sciences and Humanities

Italy III Consiglio Nazionale delle Ricerche

Japan IV Science Council of Japan

Netherlands

III Stichting voor Fundamenteel Onderzoek der Materie met Röntgen-enElektronenstralen

New Zealand I The Royal Society of New Zealand
Secretary of National Committee

M. A. R. De Benyacar, Division Fisica del Solido, Commission Nacional de Energia Atomica, Av. del Libertador 8250, 1429 Buenos Aires

The Executive Secretary, Australian Academy of Science, PO Box 783, Canberra City, ACT 2601

A. Preisinger, Institut für Mineralogie, Kristallographie und Strukturchemie der Technischen Universität Wien, Getreidemarkt 9, A-1060 Vienna

E. Legrand, Materials Sciences Department, Studiecentrum voor Kernenergie, B-2400 Mol

S. Caticha Ellis, DESCM, Instituto de Fisica, Universidade Estadual de Campinas, Campinas, São Paulo 13100

C. P. Huber, Division of Biological Sciences, National Research Council of Canada, Ottawa, Ontario K 1A 0R6

D. Boys, Departamento de Fisica, Universidad de Chile, Casilla 5487, Santiago

Gu XIaocheng, Department of Biology, Beijing University, Beijing

A. Línek, Fysikálni ústav, Československá Akademie Věd, Lisben, Na Slovance 2, 18040 Praha 8

B. Jensen, Chemical Institute BC, Danish School of Pharmacy, Universitetsparken 2, Copenhagen DK-2100

S. A. ABDEL-HADY, Faculty of Engineering \& Technology, Cairo Higher Institute of Technology, Helwan, Cairo

A. VahVASElKä, Department of Physics, University of Helsinki, Siltavuorenpenger 20 D, SF-00170 Helsinki 17

Y. Epelborn, Association Française de Cristallographie, Tour 26, 4 place Jussieu, 75230 Paris CEDEX 05

H. Peirst, Zentralinstitut für Elektronenphysik, Akademie der Wissenschaften der DDR, Mohrenstrasse 40/41, DDR-108 Berlin

H. Burzlaff, Institut für Angewandte Physik, Lehrstuhl für Kristallographie, Universität, Loewenichstrasse 22, D-8520 Erlangen

L. Zsoldos, Research Institute for Technical Physics, Hungarian Academy of Sciences, PO Box 76, H-1325 Budapest

S. K. SikKa, Scientific Officer, Neutron Physics Division, Bhabha Atomic Research Centre, Trombay, Bombay 400085

I. BAR, Ben-Gurion University of the Negev, Beer-Sheva

G. FilipPINI, Istituto di Chimica Fisica, Università di Milano, Via Golgi 19, Milano

Y. IITAKA, Faculty of Pharmaceutical Sciences, University of Tokyo, Bunkyo-ku, Tokyo

The Executive Secretary, FOMRE, Koningin Sophiestraat 124, 2595 TM's-Gravenhage

J. M. WATERS, Chemistry Department, University of Auckland, Private Bag, Auckland

* Adherence to the Union is in one of five Categories I-V, with corresponding voting powers and contributions as set out in Statutes 3.6, 5.5 and 9.4. 


\begin{tabular}{|c|c|c|}
\hline Country & Category* & Adhering Body \\
\hline Norway & I & $\begin{array}{l}\text { Det Norske Videnskaps- } \\
\text { Akademi }\end{array}$ \\
\hline Poland & I & Polska Akademia \\
\hline Portugal & I & Sociedade Portuguesa de Fisica \\
\hline South Africa & I & $\begin{array}{l}\text { South African Council for Sci- } \\
\text { entific and Industrial Research }\end{array}$ \\
\hline Spain & III & $\begin{array}{l}\text { Consejo Superior de Investiga- } \\
\text { ciones Cientificas }\end{array}$ \\
\hline Sweden & II & Kungliga Vetenskapsakademien \\
\hline Switzerland & II & $\begin{array}{l}\text { Schweizerische Gesellschaft für } \\
\text { Kristallographie }\end{array}$ \\
\hline UK & $\mathrm{V}$ & The Royal Society \\
\hline USA & $\mathrm{V}$ & $\begin{array}{l}\text { National Academy of Sciences } \\
\text { - National Research Council }\end{array}$ \\
\hline USSR & $\mathrm{V}$ & Akademija Nauk SSSR \\
\hline Yugoslavia & I & $\begin{array}{l}\text { Jugoslavenska Akademija } \\
\text { Znanosti i Umjetnosti }\end{array}$ \\
\hline
\end{tabular}

* See footnote on preceding page.

\section{National Committees for Crystallography}

\section{Argentina}

S. BAGgio (Chairman), M. E. J. DE Abeledo, L. N. BeCKA, D. Bedlivy, M. A. R. De Benyacar, A. Bonfiglioli, M. Butschowski, E. E. Galloni, M. IPOHORSKI, A. PODJARNY.

\section{Australia}

A. F. Moodie (Chairman), B. M. Gatehouse, I. Grey, T. J. Hicks, R. L. SEgall, M. R. SNow.

\section{Austria}

A. Preisinger (Chairman), H. Heritsch, O. Kratky, H. NOWOTNY, E. H. K. SCHMID, J. ZEMANN.

\section{Belgium}

J. Toussaint (Chairman), G. KING (Vice-Chairman), S. amelinckx, H. Brasseur, L. Danguy, F. Durant, H. Geise, G. Germain, R. Gevers, G. Jacobs, E. Legrand, J. Moreau, P. Piret, J. Van landuyt, M. Van MEERSSCHE, J. VENNIK.

\section{Brazil}

R. Rodrigues da Silva (Chairman), S. Caticha Ellis, J. M. Correia Neves, C. Cusatis, Y. P. Mascarenhas.

\section{Canada}

W. J. L. Buyers (Chairman), A. Beauchamp, L. T. J. Delbaere, G. Ferguson, R. B. Ferguson, C. P. Huber, K. A. KERR, O. KNOP.

\section{Secretary of National Committee}

B. F. Pedersen, Department of Pharmacy, University of Oslo, PO Box 1068, Blindern, Oslo 3

A. Pietraszko, Instytut Niskich Temperatur i Badań Strukturalnych, Polskiej Akademii Nauk, Plac Katedralny, 1, 50-950 Wroclaw

M. M. R. R. Costa, Departamento de Fisica, Universidade de Coimbra, 3000 Coimbra

P. LE R. Malherbe, International Relations Division, CSIR, PO Box 395, Pretoria 0001

S. Martínez Carrera, Instituto de Quimica Fisica 'Rocasolano', Consejo Superior de Investigaciones Cientificas, Serrano 119, Madrid 6

P. KierkegaARd, Arrhenius Laboratory, University of Stockholm, S-106 91 Stockholm

H.-B. Bürgi, Universität Bern, Laboratorium für Chemische und Mineralogische Kristallographie, Freiestrasse 3, $\mathrm{CH}-3012$ Bern

The Executive Secretary, The Royal Society, 6 Carlton House Terrace, London SWIY 5AG

H. Steinfink, Department of Chemical Engineering, The University of Texas at Austin, Austin, TX 78712

V. I. Simonov, Institute of Crystallography, Leninsky prospekt 59, Moscow 117333

B. KAMENAR, Laboratory of General and Inorganic Chemistry, Faculty of Science, Ulica Soc. Revolucije 8. 41000 Zagreb
O. WittKe (Chairman), E. Besoain, D. Boys, H. Cid, J. A. Costamagna, C. Escobar, J. Garin, C. Infante, W. Schlein, M. SuWalsky, R. Vera, J. Ward.

China, People's Republic of

Tang You-QI (Chairman), Fu Heng, Gu XIaOching, huang Jin-ling, Liang Dong-Cai, Liang Jing-kui. Lu Jia Xi, Peng Zhi-Zhong, Zhang Yuan long.

\section{Czechoslovakia}

J. GARAJ (Chairman), M. ČERNOHORSKÝ (Vice-Chairman), Č. Bárta, J. Čermák, I. Červeñ, M. Dunaj Juticó, S. Durovič, M. Handlovič, K. Huml, A. Linik. L. ULICKÝ, Z. WEISS.

\section{Denmark}

B. Lebech (Chairman), F. Broesby-Olsen, B. Blkis, J. Danielsen, R. Hazell, B. Jensen, B. Jerslev Llind. A. LindegaArd-Andersen, E. Makovicky, R. Norkl-stam, O. SIMONSEN.

\section{Egypt, Arab Republic of}

M. S. Ahmed (Chairman), Y. M. ABbas, S. A. AHDELHady, A. M. Abdel-Reheim, E. A. Abou-Salf. S. A. A. Arafa, M. A. E. Eid, I. S. Ahmed Farag. F. M. Hi:lmi. M. E. E. Helmy, S. A. SAleh, F. H. Yousef.

\section{Finland}

P. SuortTi (Chairman), K. Kurki-Suonio, V. Linidroos, A. Pajunen, T. Sahama, A. Vahvaselkä. 


\section{France}

J. Meinnel (Chairman), Y. Epelboin, R. Fourme, J. F. Petroff.

\section{German Democratic Republic}

H. NeEls (Chairman), J. Barthel, J. Bautsch, O. Brümmer, I. Heydenreich, E. Höhne, H. Peibst, M. SCHENK.

\section{Germany, Federal Republic of}

H. Burzlaff (Chairman), W. Bronger, H. Fuess, F. Liebau, W. Prandl, W. SaEnger, H. Stiller.

\section{Hungary}

K. Sasvári (Chairman), M. Farkas-Jahnke, P. Gadó, I. Hargittai, A. Kálmán, E. KrÉN, L. MalicsKó, E Nemetz, K. Simon, K. SzTrókal, I. TARJÁn, L. Zsoldos.

\section{India}

R. Chidambaram (Chairman), S. Parthasarathy, S. Ramaseshan, N. N. Saha, S. K. Sikka, A. K. Singh, O. N. Srivastaya, G. C. Trugunayat, K. Venkatesan.

$$
\text { Israel }
$$

J. Bernstern (Chairman), I. BAR, I. GoldberG, M. KAFTORY, Y. MAIER, H. REgEv, Z. SHAKKED.

\section{Italy}

G. Allegra (Chairman), M. Brunori, E. Cannillo, A. Coda, A. Della Giusta, G. Filippini, M. Fontana, C. Giacovazzo, C. M. Gramaccioli, U. Valdrè.

$$
\text { Japan }
$$

S. Hoshino (Chairman), T. AshidA, Y. IrtakA, M. KaKudo, N. Kato, S. KikUta, Y. KomURA, F. Marumo, Y. Murata, S. Nagakura, T. Ogawa, Y. Sasada, I. Sunagawa, M. Tanaka, M. Tokonami, T. UekI.

\section{Netherlands}

H. Schenk (Chairman), J. Bergsma, P. T. Beurskens,

J. Drenth, D. Feil, B. van Geelen, P. Hartman,

J. Hornstra, B. O. Loopstra, A. LoOyenga-Vos,

M. G. Northolt, A. F. Peerdeman, S. RadelaAr, J. W. VisSER, C. G. VONK, P. M. DE WOLFF.

\section{New Zealand}

W. T. Robinson (Chairman), E. N. BAKER, P. M. Black, G. J. Gainsford, B. K. Nicholson, J. M. Waters.

\section{Norway}

J. Hvostef (Chairman), O. Foss, J. Guønnes, F. Grønvold, A. Hordvik, F. Mo, B. F. Pedersen, T. G. STRAND.
Poland

K. LuKaszewicz (Chairman), J. Auleytner (ViceChairman), Z. BoJarsk1, Z. GaldeCKI, Z. KostURKIEWICZ, J. Leciejewicz, A. Pietraszko, J. ŻmiJa.

\section{Portugal}

L. M. Alte da Veiga (Chairman), M. M. R. R. Costa, J. L. DE Faria, M. O. V. DE Figueiredo, R. A. Quadrado.

\section{South Africa}

G. Heymann (Chairman), J. C. A. Boeyens, G. J. Kruger, P. Le R. Malherbe, L. R. NAsSimbeni.

\section{Spain}

S. García-Blanco (Chairman), M. Font-Altaba, R. Marquez-Delgado, S. Martínez-Carrera.

\section{Sweden}

S. Abrahamsson (Chairman), I. Olovsson (ViceChairman), B. Aurivillius, O. Beckman, D. Carlström, N. INGRi, G. JohansSon, P. KierkegaARD, B. LindQVist, I. Lindovist, B. Strandberg, A. MAGNÉLI, F. E. WickMAN.

\section{Switzerland}

H. P. Weber (Chairman), H.-B. Bürgl, D. SCHWARZENBACH.

$$
U K
$$

D. M. Blow (Chairman), D. W. J. Crulck shank, L. S. D. Glasser, A. M. Glazer, B. J. Isherwood, M. H. Loretto, J. H. Robertson, D. C. Phillips, G. A. Sim, A. C. SkApski, P. J. Wheatley, E. J. W. WhitTaker, M. M. WOOLFSON.

\section{$U S A$}

J. P. Glusker (Chairman), R. A. Newnham (Vice-Chairman), H. M. BERMAN, A. I. BIENENSTOCK, R. F. BRYAN, J. B. Cohen, W. L. Duax, D. J. Duchamp, H. A. Hauptman, W. A. Hendrickson, J. Karle, K. A. Kerr, B. W. Matthews, C. T. Prewitt, D. Sayre, B. P. Schoenborn, C. J. Sparks, JR., R. A. Sparks, D. H. TEMPLETON.

\section{$U S S R$}

G. B. Bokiy, A. I. Kitaigorodsky, Z. G. Pinsker, I. I. Shafranovsky, N. N. Sheftal, V. I. Simonov, M. M. UMANSKY, B. K. VAINSHTEIN, G. S. ZhDANOV.

\section{Yugoslavia}

D. Grdenić (Chairman), A. BezjaK, L. Golič, R. HeraK, B. Kamenar, K. Kranjc, I. Krstanović, S. Popović, V. Prodan, B. RibÁr, S. ŚćaVnIČar. 